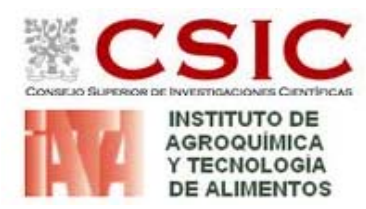

\title{
REEMPLAZO DE GRASA Y AZÚCAR EN MAGDALENAS. EFECTO SOBRE LAS PROPIEDADES REOLÓGICAS, TÉRMICAS, DE TEXTURA Y SENSORIALES
}

\author{
TESIS DOCTORAL \\ SANDRA MARTÍNEZ CERVERA
}

Dirigida por:

Dra. Ana Salvador Alcaraz

Dra. Teresa Sanz Taberner

Valencia, abril de 2013 
Dña. Ana Salvador Alcaraz, Investigadora Científica y Dña. Teresa Sanz Taberner, Científica Titular, ambas del Instituto de Agroquímica y Tecnología de Alimentos del Consejo Superior de Investigaciones Científicas (IATA-CSIC),

HACEN CONSTAR QUE:

El trabajo de investigación titulado "Reemplazo de grasa y azúcar en magdalenas. Efecto sobre las propiedades reológicas, térmicas, de textura y sensoriales" que presenta Dña. Sandra Martínez Cervera por la Universidad Politécnica de Valencia, ha sido realizado en el Instituto de Agroquímica y Tecnología de Alimentos (IATACSIC) bajo nuestra dirección y que reúne las condiciones para optar al grado de Doctor.

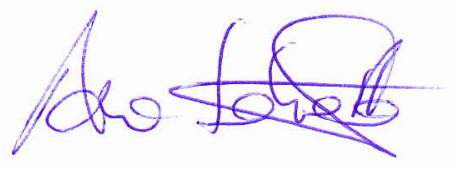

Valencia, abril de 2013.

Fdo.: Dra. Ana Salvador Alcaraz.

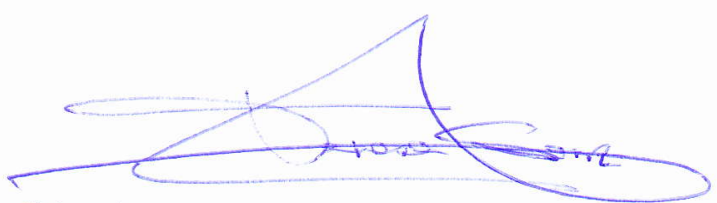

Fdo.: Dra.Teresa Sanz Taberner. 
A Concha Y Josele,

INÉS Y ELENA,

Y JAIME,

porque día a día me ayudáis

a alcanzar mis sueños.

Os quiero! 


\section{AGRADECIMIENTOS}

iQué sensación tan rara...! Desde que empecé la universidad estaba decidida a hacer "La Tesis". iEn este punto fijé mi meta! Y aquí me encuentro ahora, escribiendo la última sección, y por lo que me ha costado, la más difícil. Son muchos los momentos vividos durante todos estos años y mucho trabajo realizado, pero echando la vista atrás no ha sido tan complicado.

En toda esta trayectoria académica me he ido encontrando con muchas personas que de algún modo han intervenido en mi educación y aprendizaje, empezando por mis padres. Aún recuerdo cuando de pequeñas nos enseñaban a las tres a pronunciar bien ciertas palabras extrañas como "precipicio" en lugar de "pezipizo" (porque así era como sonaba en mi cabeza) iMira que nos costó! O cuando teníamos cualquier duda del cole, siempre encontrábamos a alguno de los dos que nos ayudaban con los deberes. Y hablando del cole... Recuerdo las clases con la pizarra, la tiza y el borrador, los ejercicios interminables que nos quitaban tiempo para jugar, las excursiones, los profesores de un millón de materias diferentes y ese grupito de pituf@s que después de clase crecíamos jugando en la plaza del ayuntamiento y que a día de hoy se ha convertido en mi querida "Penyita de la fiest".

Pero como el tiempo no se queda estancado, los años iban pasando, y llegó el momento de pasar al instituto. Allí conocí a nuevas personas, profesores y compañeros, pero sobre todo, mi mejor recuerdo de esta 
etapa fue conocer a aquel chico tímido de impresionantes ojos azules $e$ inteligente como pocas personas por aquel entonces.

A mediados del 2002 llegó la época del selectivo, iel gran paso a la universidad! aunque para mi no era la primera vez que tenía que pisar sus clases, ya había estado con tan sólo unos cuantos meses... Hay que ver que miedo le tiene todo el mundo a este examen y que insignificante se vuelve una vez lo superas. Entonces ya tenía muy claro que quería dedicarme al mundo de la alimentación y que mi camino pasaba por cursar Tecnología de Alimentos, pero para llegar allí antes tenía que hacer un primer ciclo. Nutrición Humana y Dietética era el desvío perfecto ya que era una carrera novedosa y al mismo tiempo me servía para introducirme en el mundillo. Allí fue donde, en segundo curso, conocí a una profesora de pelo rizado y diadema negra, que durante dos horas a la semana nos hablaba de un sinfín de aditivos. Ese mismo verano al terminar el curso, en julio, decidí hacer una estancia en el laboratorio de Propiedades Físicas y Sensoriales con la intención de aprender el mundillo de la investigación fuera de la UV, ly ésto pareció gustarme! Julio tras julio acudía al laboratorio para ayudar en lo que fuera con tal de no aburrirme en casa por las mañanas, mientras que mi padre me decía "muy bien Sandra, tu ves metiendo el culito en el IATA" (iQué bien lo hice eh, papá!).

Después de Nutrición, tal y como tenía en mente, me matriculé en Ciencia y Tecnología de Alimentos, aunque esta vez en la Universidad Politécnica. Y fue entonces cuando viví mis mejores años como universitaria, rodeada de buenos profesores y de un grupo encantador de compañeras que siempre estaban dispuestas a ayudar en lo que sea o a salir a tomar "un algo" después de las clases. Compañeras que a día de hoy son 
amigas. Porque en el poli es difícil no hacer amigos, ile echas más horas que un tonto!

Pero los años siguieron pasando y llegó junio de 2007. Tenía que decidir dónde quería hacer la tesis y con mi título en mano, en julio (no podía ser de otra manera), vine de nuevo al IATA. Aquí encontré un gran grupo de personas maravillosas. Fue donde descubrí que tengo otro "brazo derecho" y otra "espalda". Todas ellas me acogieron y lucharon como pudieron para que consiguiera una beca, porque aunque se puede hacer investigación sin cobrar un sueldo no se puede hacer sin dinero para La Ciencia, y esto tristemente será evidente dentro de unos años, si no lo está siendo ya... Pero... ipor fin!, en mayo de 2009, illovió una beca con mi nombre! Justo en el momento que me empezaba a plantear la forma de seguir trabajando con mis magdas y al mismo tiempo ganar un dinerillo por otro lado. Por fin se podía ver la luz de la meta.

Durante estos últimos cuatro años he vivido grandes experiencias y aprendido a manejar equipos complejos, a enseñar a mis catadores los secretos de las magdalenas, a interpretar extrañas gráficas, a escribir artículos que gusten a los revisores, a hacer una estancia fuera de mi territorio y adaptarme a otro ritmo de trabajo, a escuchar seminarios, conferencias y ponencias sobre temas del mundillo de la ciencia de los alimentos, a mantener interesantes conversaciones y a convivir con todas mis compañeras (y esto, según el día, no es nada fácil). Incluso, de rebote, me he aficionado a hacer tartas, bizcochos y pequeños pastelitos para ponerle un puntito dulce a la vida. Han sido cuatro años muy enriquecedores y de los que, de nuevo, me llevo algunas amigas conmigo. 
Pero lo importante es que todos estos años de mi vida han sido como han sido gracias a todas las personas que me rodean, y es que $\sin$ todos vosotros no creo que hubiera sido capaz de ser ni la mitad persona de lo que hoy soy. Gracias a toda la gente que se ha cruzado en mi camino durante estos 29 años.

Gracias a todos de corazón.

Y como diría "Ovometría y ciencias afines"...
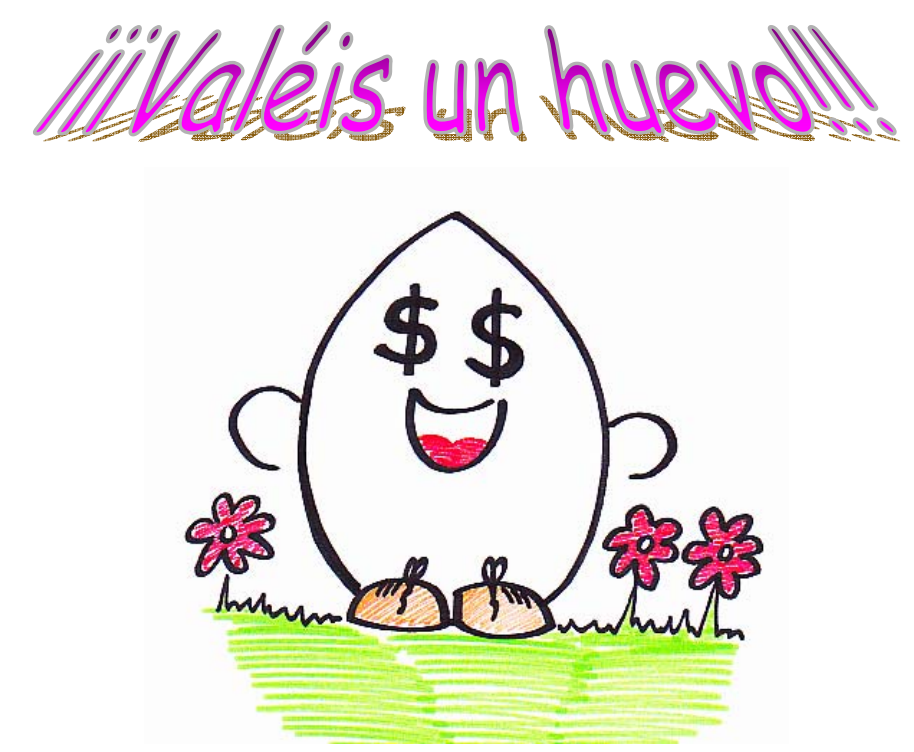


\section{RESUMEN}

ReEmplazo de grasa y azúcar en magdalenas. EFEcto SOBRe LAS PROPIEDADES REOLÓGICAS, TÉRMICAS, DE TEXTURA Y SENSORIALES.

El presente trabajo de tesis se centra en el estudio de las propiedades reológicas, térmicas, de textura y sensoriales de magdalenas en las que se ha reemplazado parcial o totalmente la grasa o el azúcar.

La masa de las magdalenas es una emulsión de aceite en agua compuesta por una base de harina que incorpora grasa y azúcar como ingredientes principales y, como opcionales, huevo, leche y otros componentes. El producto final se caracteriza por tener una estructura porosa y un elevado volumen, lo cual le confiere una textura esponjosa. El azúcar, la grasa y la harina son los ingredientes con mayor funcionalidad en los productos de bollería, por lo que es muy difícil encontrar un sustituto capaz de realizar sus mismas funciones.

Las características reológicas de la masa se han determinado mediante el estudio del comportamiento pseudoplástico (ensayos rotacionales) y viscoelástico (ensayos oscilatorios). La viscosidad de la masa es una propiedad importante en los productos horneados aireados, ya que dependiendo de ésta obtendremos un nivel óptimo de incorporación de aire durante el amasado. Los valores de viscosidad obtenidos en función de la velocidad de cizalla indicaron que las masas estudiadas se encontraban dentro de la zona pseudoplástica. Al reemplazar la grasa por fibra de cacao se obtuvieron valores de consistencia mayores a los obtenidos por la muestra control. Un aumento excesivo de la consistencia podría acarrear problemas en la manipulación de la masa durante el llenado de los moldes (dosificación) y problemas de limpieza de la maquinaria. Por el contrario, en el reemplazo de azúcar por polidextrosa y sucralosa se obtuvieron valores de consistencia inferiores. La medida de la gravedad específica proporciona información sobre la cantidad de aire incorporado durante el amasado y se ha demostrado que 
tanto el azúcar como sus sustitutos favorecen dicha incorporación en mayor o menor medida. Por otro lado, en el caso de reemplazo de grasa por los sustitutos empleados se observó una mejora en la incorporación de aire.

Los cambios estructurales que ocurren en la masa durante el horneado son factores determinantes en la formación y evolución de las burbujas y en la estructura y textura del producto final. Por lo general, las masas mostraron una disminución de los módulos viscoelásticos estudiados durante la primera etapa de calentamiento, que está asociada únicamente al efecto del aumento de la temperatura. A partir de los $45{ }^{\circ} \mathrm{C}$, dicha disminución está asociada a la formación de $\mathrm{CO}_{2}$ y a su difusión y expansión dentro de las celdas de aire. A partir de una determinada temperatura se produce un punto de inflexión en la curva, que está relacionado con la gelatinización del almidón y la coagulación de las proteínas, es decir, del paso de una matriz semilíquida a una matriz sólida. La presencia de azúcar, así como de la mayoría de los sustitutos de azúcar empleados, dio lugar a un retraso en la temperatura a la cual se produce la inflexión de la curva de calentamiento favoreciendo la expansión del $\mathrm{CO}_{2}$ y del vapor de agua. En el caso del reemplazo de grasa no se pudo determinar la temperatura a la cual se produjo el punto de inflexión de la curva, aunque sí se observó un suave aumento de los valores de los módulos viscoelásticos.

Para conocer mejor cómo afectan los sustitutos de grasa o de azúcar en el proceso de gelatinización de almidón se realizó un estudio de las propiedades térmicas de la masa mediante calorimetría diferencial de barrido, observándose en todos los casos un pico alrededor de los $100{ }^{\circ} \mathrm{C}$, que se corresponde con la gelatinización del almidón.

Para llevar a cabo el estudio de los parámetros de textura se realizó un análisis de perfil de textura así como ensayos de penetración y pegajosidad en el producto final. Los parámetros de dureza y elasticidad son los que mejor se asociaron con la frescura del producto y fueron los parámetros que más se afectaron por el reemplazo tanto de grasa como de azúcar. El empleo de eritritol como sustituto de azúcar aumentó considerablemente la dureza del 
producto mientras que para el resto de los edulcorantes se obtuvieron valores similares a la formulación control. Por otro lado, cuando la grasa fue reemplazada por fibra de cacao o por Nutriose ${ }^{\circledR}$, los valores de dureza y elasticidad disminuyeron.

Además de la textura, existen otras características relacionadas con la estructura de la miga que pueden influir en la aceptabilidad del producto como son la forma, altura, volumen, recuento y distribución de celdas de aire. Todos estos parámetros se vieron modificados negativamente en mayor o menor medida cuando el azúcar o la grasa fueron reemplazados, por lo que para estos casos el empleo de goma xantana y doble concentración de agente impulsor sería aconsejable.

Se han evaluado las características sensoriales de las magdalenas generando los descriptores que mejor definan la calidad sensorial del producto utilizando un panel de jueces entrenados y, además, se ha estudiado la aceptación de los nuevos productos utilizando un panel de consumidores. En las muestras donde se utilizó fibra de cacao como sustituto de grasa el panel de jueces entrenados determinó los siguientes descriptores: altura, color a chocolate, esponjosidad, elasticidad, adherencia al molde, cohesión, dificultad en la masticación y deglución, sabor amargo, sabor dulce y sabor a chocolate. La formulación control se definió como la formulación con mayor adherencia al molde, altura, esponjosidad, elasticidad, sabor y color a chocolate. Por el contrario, las formulaciones con mayor porcentaje de sustitución de grasa por fibra de cacao se definieron como más cohesivas, con peor masticabilidad, y mayor sabor amargo. Los consumidores evaluaron la aceptabilidad de todas las muestras elaboradas con grasa y azúcar reducidas valorando la apariencia, color, textura, sabor, dulzor y aceptación general. En todos los casos estudiados, la formulación control (con la totalidad de la grasa y azúcar) fue bien valorada por los consumidores en todos los atributos. Cuando se reemplazó el azúcar por edulcorantes no se encontraron diferencias en la aceptación de las formulaciones con $100 \%$ de reemplazo de azúcar por sorbitol o maltitol o en el caso de reemplazo del $50 \%$ de azúcar por polidextrosa y 
sucralosa. Al igual que ocurrió con el reemplazo de azúcar, cuando el 50\% de la grasa fue reemplazada por $\operatorname{Nutriose}^{\circledR}$ no se encontraron diferencias en aceptación con respecto a la formulación control. 


\section{RESUM}

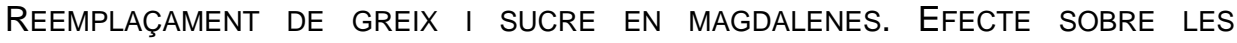
PROPIETATS REOLÒGIQUES, TÈRMIQUES, DE TEXTURA Y SENSORIALS.

El present treball de tesis es centra en l'estudi de les propietats reològiques, tèrmiques, de textura i sensorials de magdalenes a les quals s'ha reemplaçat parcialment o total el greix o el sucre.

La massa de les magdalenes és una emulsió d'oli en aigua composta per una base de farina que incorpora greix i sucre com ingredients principals $i$, com opcionals, ou, llet i altres components. El producte final es caracteritza per tindre una estructura porosa i un elevat volum, el qual confereix una textura esponjosa. El sucre, el greix i la farina són els ingredients amb major funcionalitat als productes de brioxeria, pel qual és molt difícil trobar un substitut capaç de realitzar les seues mateixes funcions.

Les característiques reològiques de la massa s'han determinat mitjançant l'estudi del comportament pseudoplàstic (assajos rotacionals) i viscoelàstic (assajos oscil-latoris). La viscositat de la massa és una propietat important als productes enfornats airejats, ja que depenent d'aquesta obtindrem un nivell òptim d'incorporació d'aire durant el pastat. Els valors de viscositat obtinguts en funció de la velocitat de cisalla van indicar que les masses estudiades es trobaven dins de la zona pseudoplàstica. Al reemplaçar el greix per fibra de cacau s'obtingueren valors de consistència majors als obtinguts per la mostra de control. Un augment excessiu de la consistència podria ocasionar problemes en la manipulació de la massa durant l'ompliment dels motles (dosificació) i problemes de neteja de la maquinària. Per contra, al reemplaçament de sucre per polidextrosa i sucralosa s'obtingueren valors de consistència inferiors. La mida de la gravetat específica proporciona informació sobre la quantitat d'aire incorporat durant el pastat i s'ha demostrat que tant el sucre com els seus substituts afavoreixen dita incorporació en major o menor 
mida. Per altra banda, en el cas de reemplaçament de greix pels substituts empleats es va observar una millora en la incorporació d'aire.

Els canvis estructurals que ocorren en la massa durant l'enfornat són factors determinants en la formació i evolució de les bombolles i en l'estructura i textura del producte final. En general, les masses mostraren una disminució dels mòduls viscoelàstics estudiats durant la primera etapa de calfament, que està associada únicament a l'efecte de l'augment de la temperatura. A partir de $45^{\circ} \mathrm{C}$, dita disminució està associada a la formació de $\mathrm{CO}_{2}$ i a la seua disfunció i expansió dins de les cel.la d'aire. A partir d'una determinada temperatura es produeix un punt d'inflexió en la corba, que està relacionat amb la gelatinització del midó i la coagulació de les proteïnes, és a dir, del pas d'una matriu sòlida. La presència de sucre, així com de la majoria dels substituts de sucre empleats, va donar lloc a un retard en la temperatura a la qual es produeix la inflexió de la corba de calfament afavorint l'expansió del $\mathrm{CO}_{2}$ i del vapor d'aigua. En el cas del reemplaçament de greix no es va poder determinar la temperatura a la qual es va produir el punt d'inflexió de la corba, encara que sí que es va observar un suau augment dels valors dels mòduls viscoelàstics.

Per tal de conèixer millor com afecten els substituts de greix o de sucre en el procés de gelatinització de midó es va realitzar un estudi de les propietats tèrmiques de la massa mitjançant calorimetria diferencial d'agranat, observantse en tots els casos un pic al voltant dels $100^{\circ} \mathrm{C}$, que es correspon amb el procés de gelatinització del midó.

Per tal de dur a cap l'estudi dels paràmetres de textura es va realitzar una anàlisi de perfil de textura així com assajos de penetració i enfigassament al producte final. Els paràmetres de duresa i elasticitat són els que millor es van associar amb la frescor del producte i van ser els paràmetres que més s'afectaren pel reemplaçament tant de greix com de sucre. L'ús de eritritol com a substitut de sucre va augmentar considerablement la duresa del producte mentre que per a la resta dels edulcorants es van obtindre valors similars a la formulació control. Per altra banda, quan el greix va ser reemplaçat tant per 
fibra de cacau com per Nutriose ${ }^{\circledR}$, els valors de duresa i elasticitat van disminuir.

A més a més de la textura, també existeixen altres característiques relacionades amb l'estructura de la molla que poden influir en l'acceptabilitat del producte com són la forma, l'altura, el volum, recompte i distribució de cel-les d'aire. Tots aquests paràmetres es van veure modificats negativament en major o menor mida quan el sucre o el greix van ser reemplaçats, pel que per a aquestos casos l'ús de goma xantana i doble concentració d'agent impulsor seria aconsellable.

S'han avaluat les característiques sensorials de les magdalenes generant els descriptors que millor definisquen la qualitat sensorial del producte utilitzant un panell de jutges entrenats i a més a més s'ha estudiat l'acceptació dels nous productes utilitzant un panell de consumidors. En les mostres on es va utilitzar fibra de cacau com a substitut de greix el panell de jutges entrenats va determinar els següents descriptors: altura, color a xocolate, esponjositat, elasticitat, adherència al motle, cohesió, dificultat en la masticació i deglució, sabor amarg, sabor dolç i sabor a xocolate. La formulació control es va definir com la formulació amb major adherència al motle, altura, esponjositat, elasticitat, sabor i color a xocolate. Per contra, les formulacions amb major percentatge de substitució de greix per fibra de cacau es van definir com més cohesives, amb pitjor masticabilitat, i major olor i sabor amarg. Els consumidors avaluaren l'acceptabilitat de totes les mostres elaborades amb greix i sucre reduïts valorant l'aparença, color, textura, sabor, dolçor i acceptació general. En tots els casos estudiats, la formulació control (amb la totalitat del greix i sucre) va ser ben valorada pels consumidors en tots els atributs. Quan es va reemplaçar el sucre per edulcorants no es van trobar diferències en l'acceptació de les formulacions amb 100\% de reemplaçament de sucre per sorbitol o maltitol o en el cas de reemplaçament del $50 \%$ de sucre per polidextrosa i sucralosa. A l'igual que va ocórrer amb el reemplaçament de sucre, quan el $50 \%$ del greix va ser reemplaçada per Nutriose ${ }^{\circledR}$ no es van trobar diferències en l'acceptació amb respecte a la formulació control. 
XVIII 


\section{SUMMARY}

FAT AND SUGAR REPLACEMENT IN SPANISH MUFFINS. EFFECT IN RHEOLOGICAL, THERMAL, TEXTURAL AND SENSORY PROPERTIES.

This thesis is focused on the study of the rheological, thermal, textural and sensory properties of muffins in which fat or sugar were partially or completely replaced.

Muffin batters are an emulsion of oil in water consisting of base grease which incorporates flour and sugar as the main ingredients and, as optional, egg, milk and other components. The final product is characterized by a porous structure and high volume, which gives a spongy texture. The sugar, fat and flour are more functional ingredients in bakery products, making it very difficult to find a replacement capable of performing their same functions.

The rheological characteristics of the batter were determined by studying the pseudoplasticity (rotational tests) and viscoelasticity (oscillatory tests). The viscosity of the batter is an important property in aerated baked goods, because depending on this, an optimal level of air incorporation during mixing can be achieved. The viscosity values obtained as a function of shear rate indicated that the batters studied were within the pseudoplastic area. By replacing fat with cocoa fiber consistency values were higher than those obtained for the control sample. An excessive increase of the consistency could cause problems in handling the batter during the mold filling (dosing) and cleaning problems of the machine. By contrast, in the sugar replacement with polydextrose and sucralose consistency values were lower. The specific gravity measurement provides information about the amount of air incorporated during kneading, and it has been shown that both sugar substitutes improve this incorporation. Furthermore, in the case of replacement of the fat substitutes used an incorporation of air was also observed.

The structural changes that occur during baking in batter are determining factors in the formation and evolution of the bubbles and the 
structure and texture of the final product. Usually, the batters showed a decrease in the viscoelastic modules studied during the first heating step, which is associated only to the effect of temperature increment. From $45^{\circ} \mathrm{C}$, this reduction is associated with the formation of $\mathrm{CO}_{2}$ and its diffusion and expansion into the air cells. From a certain temperature is a turning point in the curve, which is related to the gelatinization of the starch and protein coagulation, that is, the transition from matrix slurry to solid matrix. The presence of sugar, and most of the sugar substitutes used, showed a delay in the temperature at which the inflection of heating curve occurs favouring the expansion of the $\mathrm{CO}_{2}$ and water vapour. In the case of fat replacement could not determine the temperature at which there was the inflection point of the curve, although a slight increment was observed in the viscoelastic modulus values.

For a better understanding about how they affect fat substitutes or sugar in the process of gelatinization of starch, a study of the batter thermal properties was carried out by differential scanning calorimeter, being observed in all cases a peak around $100^{\circ} \mathrm{C}$, which correspond to the starch gelatinization process.

To carry out the study of the textural parameters texture profile as well as penetration testing and tackiness are analyzed in the final product. The hardness and elasticity parameters are the best associated with product freshness and the parameters were more affected by the replacement of both fat and sugar. The use of erythritol as a sugar substitute considerably increased hardness to the product while the remaining values were obtained sweeteners similar to the control formulation. Furthermore, when the fat was replaced by cocoa fibre as Nutriose ${ }^{\circledR}$, the elasticity and hardness values decreased.

In addition to the texture, there are also other characteristics related to the crumb structure may influence the acceptability of the product such as the shape, height, volume, counting and distribution of air cells. All these parameters were modified negatively greater or lesser extent when the sugar or 
fat were replaced, so that in these cases the use of xanthan gum and double concentration of bulking agent would be advisable.

Sensory characteristics of the Spanish muffins were evaluated generating descriptors that best define the sensory quality of the product using a trained panel and also studying the acceptance of new products using a consumer panel. In samples where cocoa fibre was used as a fat substitute the trained panel identified the following descriptors: height, colour of chocolate, fluffiness, elasticity, adhesion to the mould, cohesion, difficulty in chewing and swallowing, bitter taste, sweet chocolate flavour. The control formulation is defined as the formulation with increased adhesion to the mould height, sponginess, elasticity, chocolate flavour and colour. By contrast, formulations with higher percentage of fat by replacing cocoa fibre as defined more cohesive, with worse chewiness, and higher odour and bitter taste. Consumers evaluated the acceptability of all samples prepared with reduced fat and sugar evaluating the appearance, colour, texture, flavour, sweetness and overall acceptance. In all cases studied, the control formulation (with all the fat and sugar) was well appreciated by consumers in all attributes. When sugar was replaced by sweeteners no differences were found in the acceptance of the formulations with $100 \%$ replacement of sugar or sorbitol or maltitol in the case of replacement of $50 \%$ of sucralose sugar and polydextrose. As happened with the replacement of sugar, when $50 \%$ of the fat was replaced by Nutriose ${ }^{\circledR}$ no differences in acceptance for the control formulation. 
XXII 
ÍNDICE 



\section{ÍNDICE}

INTRODUCCIÓN

Pág. 1

OBjetivos

Pág. $\quad 25$

ESTRUCTURACIÓN DE LA TESIS

Pág. $\quad 29$

Capítulo 1.

Pág. $\quad 35$

Martínez-Cervera, S., Sanz, T., Salvador, A. y Fiszman, S.M. (2012). Rheological, textural and sensorial properties of low-sucrose muffins reformulated with sucralose/polydextrose. LWT-Food Science and Technology 45, 213-220.

CAPítulo 2.

Pág. 59

Martínez-Cervera, S., de la Hera, E., Sanz, T., Gómez, M. y Salvador, A. (2012). Effect of using erythritol as a sucrose replacer in making Spanish muffins incorporating xanthan gum. Food Bioprocess and Technology 5 (8), 3203-3216.

CAPÍtULO 3.

Pág. 91

Martínez-Cervera, S., Salvador, A. y Sanz, T. (2013). Comparison of different polyols as total sucrose replacers in muffins: thermal, rheological, texture and acceptability properties. Food Hydrocolloids.

CAPítulo 4.

Pág. 117

Martínez-Cervera, S., Salvador, A., Muguerza, B., Moulay, L. y Fiszman, S.M. (2011). Cocoa fibre and its application as a fat replacer in chocolate muffins. LWT-Food Science and Technology 44, 729-736. 
Capítulo 5.

Pág. 145

Martínez-Cervera, S., de la Hera, E., Sanz, T, Gómez, M. y Salvador, A. (2012). Effect of nutriose on rheological, textural and sensorial characteristics of spanish muffins. Food Bioprocess and Technology DOI 10.1007/s11947-0120939-x

RESULTADOS Y Discusión Pág. 171

CONCLUSIONES

Pág. 183

XXVI 
INTRODUCCIÓN 



\section{INTRODUCCIÓN}

\section{Productos de bollería: magdalenas}

\subsection{Definición}

Las magdalenas son un tipo especial de bizcocho obtenido por horneado de la masa en un molde de papel. La masa de las magdalenas es una emulsión de aceite en agua compuesta por una base de harina que incorpora grasa y azúcar como ingredientes principales y como opcionales huevos, leche y otros componentes. El producto final se caracteriza por tener una estructura porosa y un elevado volumen, lo cual le confiere una textura esponjosa. Es un producto altamente apreciado por los consumidores debido a su buen sabor y textura, sin embargo, es un producto con un alto contenido en calorías.

\subsection{Hábitos de consumo}

Durante las últimas décadas se ha producido una disminución en el consumo de pan que coincide con un aumento en el consumo de productos de bollería (Ministerio de Medio Ambiente y Medio Rural y Marino, 2008) y dentro de este grupo, aquellos productos que suponen una reducción en carga energética y/o azúcar son los que más han visto aumentado su consumo (Ministerio de Medio Ambiente y Medio Rural y Marino, 2006). La principal diferencia nutricional entre estos productos es la cantidad y tipo de grasas que contienen. El pan es un producto con baja o nula concentración de grasas mientras que los productos de bollería, generalmente, están compuestos por una amplia gama de productos de alto contenido en azúcares y grasa, siendo especialmente elevada la concentración de ácidos grasos saturados (Varela et al., 1993).

Tradicionalmente en España, las magdalenas son un alimento consumido tanto en el desayuno como en la merienda, su textura suave y esponjosa las convierte en un alimento muy consumido por toda la población y muy especialmente por niños y personas mayores. 


\section{Ingredientes y su funcionalidad}

Los ingredientes que normalmente se utilizan en la elaboración de las magdalenas son harina, azúcar, aceite, huevo, leche y un agente impulsor. Cada uno de estos ingredientes cumple unas funciones determinadas dentro de la masa que finalmente repercuten en las características de calidad y sensoriales del producto final.

\subsection{Funcionalidad de la harina}

La harina es el ingrediente principal de los productos de bollería y el que les proporciona las características de textura, estructura y sabor gracias a las proteínas y el almidón que contiene. La estructura de la miga se crea cuando el almidón sufre el proceso de gelatinización y las proteínas se coagulan durante la cocción, ayudando a retener el aire que se ha incorporado durante el amasado así como el gas que se ha generado durante el horneado de la masa dando lugar a la estructura tipo "colmena de abejas" típica de las magdalenas/bizcochos. Esta estructura repercute en la textura del producto horneado obteniéndose una miga relativamente blanda, elástica y esponjosa. Además, el almidón también interviene manteniendo la viscosidad adecuada en la masa.

\subsection{Funcionalidad del azúcar}

El azúcar es uno de los ingredientes con mayor funcionalidad en los productos de bollería, por lo que es muy difícil encontrar un sustituto capaz de realizar sus mismas funciones. Las funciones del azúcar, además de aportar sabor dulce, son diversas, como actuar como agente de carga en las masas, ayudar a estabilizar la humedad en el producto final y limitar el hinchamiento del almidón, lo cual se traduce en una textura más fina del producto final (Beesley, 1995). De hecho, la presencia de azúcar aumenta la temperatura de gelatinización del almidón y de la desnaturalización proteica, así como la viscosidad de la masa. También, ayuda a promover la agregación de cristales 
de grasa y, por tanto, mejora la captación de aire durante el batido y la estabilización de la burbuja durante el horneado (Beesley, 1995). Por último, mejora la microestructura, la porosidad y el volumen del producto final y contribuye al pardeamiento u oscurecimiento, tanto de la corteza como de la miga del producto, en condiciones no ácidas.

\subsection{Funcionalidad de la grasa}

Por su parte, la grasa cumple una serie de funciones importantes en los productos de bollería. Al igual que el azúcar, la grasa ayuda a promover la incorporación de aire durante el amasado, lo cual puede suponer un mayor volumen y una textura esponjosa en el producto final. Además, reduce el fenómeno de retrogradación del almidón lo cual produce un aumento de la vida útil del producto (Gómez, 2008). De hecho, evita el desmenuzamiento de la miga favoreciendo que el producto sea más compacto al tiempo que esponjoso. Con respecto al sabor y aroma, evita la sensación de sequedad en la boca del producto final y es vehículo de muchos aromas debido al comportamiento lipofílico de estos últimos. Por último, aporta una textura más suave y tierna al producto.

La eliminación total de la grasa de la formulación de las magdalenas da lugar a la obtención de un bizcocho tipo soletilla. Por lo tanto, la incorporación o no de la grasa determina el tipo de producto final.

\subsection{Funcionalidad del huevo}

El huevo cumple con unas funciones muy importantes en la formulación de alimentos de bollería tipo magdalenas. Es responsable de la incorporación de aire y la formación de los puntos de nucleación. Al batir la clara, y debido a las proteínas que contiene, se forma una espuma con mucho aire ocluido que, posteriormente, actuará como puntos de nucleación para el gas producido durante el horneado. Además, permite emulsionar la masa batida gracias a la presencia de lecitina en la yema, que ayuda a estabilizar las partículas de grasa y de aire, evitando que la masa se separe en diferentes fases. Por otro 
lado, favorece la formación de la estructura de la miga al coagular las proteínas durante el horneado. Aporta color amarillento a la miga gracias a los colorantes presentes en la yema y favorece el pardeamiento de la corteza al reaccionar las proteínas con el azúcar. Además, aumenta la humedad del producto y el valor nutricional ya que la yema es rica en vitaminas y minerales (Conforti, 2006).

\subsection{Funcionalidad de la leche}

La leche es un ingrediente que, si bien no es mayoritario, cumple una función muy importante puesto que al incorporarla en la formulación también se incorpora agua. El agua, además de disolver el resto de ingredientes solubles y facilitar el mezclado, es un componente necesario para que se produzca la gelatinización del almidón durante el horneado. Pero además, la leche contribuye al sabor del producto y la lactosa y las proteínas que contiene intervienen en la reacción de Maillard aportando color tostado. Por último, la leche contiene vitaminas y minerales que enriquecen el producto.

\subsection{Funcionalidad del agente impulsor}

Los impulsores son ingredientes que al entrar en contacto entre ellos sufren una reacción ácido-base, liberando al medio en el que se encuentran moléculas de $\mathrm{CO}_{2}$. Estas moléculas son las responsables, junto con el aire incorporado durante el batido, de las burbujas obtenidas en la miga en el producto final. Esta reacción ocurre al final del horneado y es importante que se de en este momento, ya que por lo contrario no se retendría el gas formado y se perdería la estructura y el volumen característicos de estos productos. Entre los ácidos que se pueden utilizar están el ácido acético, cítrico, tartárico o mezcla de láctico y acético y como dador de $\mathrm{CO}_{2}$ el más empleado es el bicarbonato sódico. 


\section{Principales problemas de salud relacionados con la alimentación: obesidad y diabetes}

El aumento de las enfermedades cardiovasculares y de la obesidad, así como de otras enfermedades relacionadas con la alimentación en la población (INE, 2006), ha provocado una mayor preocupación por la relación de la dieta con la salud y un mayor interés del consumidor por conocer la composición de los alimentos, valorando más positivamente aquellos que poseen un mejor perfil nutricional y reducido valor calórico. Es por ello que durante los últimos años se ha producido un aumento en el consumo de versiones de los alimentos bajos en grasas o azúcar (Sandrou \& Arvanitoyannis, 2000).

La obesidad es una enfermedad crónica reconocida como uno de los principales problemas de salud pública en los países desarrollados debido a su alta prevalencia y a sus consecuencias sobre la calidad de vida y la morbimortalidad (Trallero \& Humanes, 2004). En España, la obesidad es una enfermedad que afecta al $17,3 \%$ de los varones y al $14,7 \%$ de las mujeres mayores de 18 años, y estos porcentajes van en aumento a medida que aumenta la edad de la población (INE, 2012). Los principales desencadenantes de esta enfermedad son la mala alimentación o alimentación no equilibrada y el exceso de sedentarismo de la sociedad.

Por otro lado, el azúcar tiene un alto índice glicémico, por lo que es un ingrediente poco adecuado para su consumo en personas afectadas de diabetes. Este grupo de población debe reducir el consumo de productos ricos en azucares simples, como lo son la mayoría de los productos de bollería.

Por tanto, la reducción de grasas y azúcares simples de los productos de bollería se constituye como una de las prioridades en el desarrollo de alimentos de la industria alimentaria. Sin duda la mejora del perfil nutricional de los alimentos, en combinación con el fomento de la actividad física supone un empuje hacia una forma de vida más saludable. 


\section{Ingredientes utilizados como sustitutos de azúcar en productos de bollería}

Debido a las diferentes funciones que tiene el azúcar en un producto de bollería, es muy difícil encontrar un único ingrediente que sea capaz de reemplazarlo. Existen dos grandes familias de edulcorantes: los que actúan como edulcorante y agente de carga al mismo tiempo y los que únicamente tienen funcionalidad de edulcorante. Por otro lado, también es posible sustituir el azúcar por sustancias que únicamente presentan funciones de agente de carga en combinación con un edulcorante que aporte el sabor dulce.

Todos estos sustitutos tienen que cumplir dos requisitos para poder aplicarse en productos de bollería. En primer lugar, deben ser térmicamente estables en el intervalo de temperaturas de horneado. Por otro lado, deben ser solubles en agua para obtener una masa lo más homogénea posible.

\subsection{Edulcorantes con función de agente de carga}

\subsubsection{Polioles}

Tradicionalmente los polioles se han considerado como buenos sustitutos del azúcar en productos de bollería (Olinger \& Velasco, 1996) y sus propiedades han sido estudiadas por un gran número de autores (Kamel \& Rasper, 1988; Baeva et al., 2003; Ronda et al., 2005). Los polioles se utilizan como sustitutos de azúcar en productos donde el dulzor, el volumen y la textura son parámetros importantes. Pero además, los polioles presentan tres características ventajosas frente al empleo de azúcar: son azúcares difícilmente fermentables por las bacterias de la boca por lo que no producen caries dental; tienen una baja respuesta glicémica, por lo que son ingredientes aptos para personas diabéticas y, por último, la mayoría de los polioles poseen menor contenido calórico (entre $0.2-2.6 \mathrm{Kcal} / \mathrm{g}$ ) que el azúcar $(4 \mathrm{Kcal} / \mathrm{g})$ por lo que son adecuados para aplicar en productos bajos en calorías o en productos donde se quiera reducir la carga calórica. 
El poder edulcorante de los polioles varía de unos a otros por lo que, en ocasiones, es adecuada una combinación de ellos para una correcta obtención del dulzor (Figura 1).

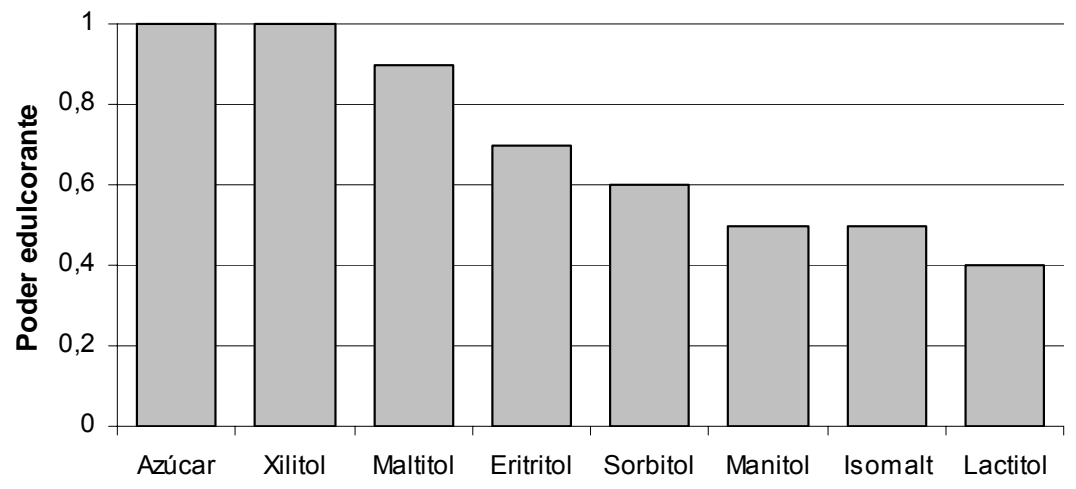

Figura 1. Poder edulcorante de los diferentes polioles y del azúcar.

No obstante, los polioles presentan el problema de ser susceptibles a la fermentación por las bacterias del colon, por lo que es habitual que produzcan un ligero malestar debido a flatulencias. Es por esta razón que ciertas personas necesiten una adaptación gradual a la ingesta de polioles, de modo que, si se administra inicialmente una pequeña cantidad del ingrediente, con el tiempo son capaces de tolerar concentraciones normales sin que ello suponga malestar corporal (McNutt \& Sentko, 1996).

Los polioles más comúnmente utilizados son el sorbitol, maltitol, isomaltitol, manitol, lactitol, xilitol y eritritol (Figura 2). Sus características se detallan a continuación.

Sorbitol. Se produce industrialmente mediante hidrogenación de la glucosa obtenida a partir de almidón o del azúcar invertido (Bornet, 1994). El poder edulcorante de este poliol es del $60 \%$ respecto al del azúcar (Zumbé et al., 2001).

Maltitol. Este poliol no se encuentra de forma natural en los alimentos por lo que es necesario obtenerlo industrialmente a partir de maltosa mediante 
un proceso de hidrogenación (Bornet, 1994). Su poder edulcorante es del 90\% respecto al poder edulcorante del azúcar (Zumbé et al., 2001).

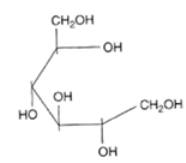

Sorbitol

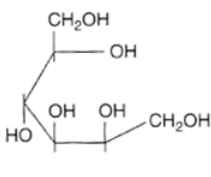

Manitol

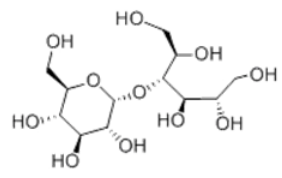

Maltito

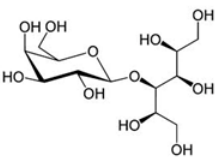

Lactitol<smiles>C[C@@H]1[C@@H](CO)O[C@@H](OC[C@H](O)[C@@H](O)[C@H](O)[C@H](O)CO)[C@H](O)[C@H]1O</smiles>

Isomaltito|

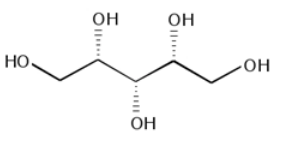

Xilitol

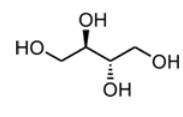

Eritritol

Figura 2. Estructura molecular de los diferentes polioles.

Isomaltitol. Es un disacárido formado por mezcla equimolar de glucomanitol y glucosorbitol. Se obtiene industrialmente por hidrogenación catalítica a partir de isomaltulosa (Bornet, 1994). El poder edulcorante de este poliol es del 50\% respecto al poder del azúcar (Zumbé et al., 2001).

Manitol. La forma más sencilla de obtener manitol es por extracción directa a partir de algas marinas. Tiene un poder edulcorante del $50 \%$ respecto al del azúcar. Los estudios realizados hasta el momento revelan que el manitol no es un sustituto adecuado en magdalenas, ya que el producto final es de peor calidad (menor color, volumen y aceptación sensorial) (Ronda et al., 2005; Psimouli \& Oreopoulou, 2012).

Lactitol. Es un disacárido compuesto por sorbitol y galactosa, que se obtiene por hidrogenación catalítica a partir de la lactosa. El poder edulcorante del lactitol es del $40 \%$ respecto al del azúcar, por lo que en este caso es necesario el uso de un edulcorante intenso para no sufrir pérdidas de sabor en el producto final (Young, 2006). No obstante, es un ingrediente que actúa muy bien como agente de carga ya que las propiedades de la masa son similares a las obtenidas con el azúcar (Psimouli \& Oreopoulou, 2012).

Xilitol. Se encuentra de forma natural en frutas y verduras y es el único poliol con igual poder edulcorante que el azúcar (Bond \& Dunning, 2006). Al 
igual que el lactitol, es un buen agente de carga en masas batidas ya que no se observan grandes diferencias respecto al azúcar (Ronda et al., 2005).

Eritritol. Es un poliol de nueva generación con varias ventajas frente al resto de polioles. El perfil metabólico del eritritol es único. Debido a su bajo peso molecular el $90 \%$ de la cantidad ingerida es absorbida en el intestino delgado y eliminada por orina sin ser metabolizado. El 10\% del eritritol que pasa al intestino grueso es parcialmente metabolizado y excretado. Es por esta razón, que el eritritol es el único poliol sin efectos laxantes, ya que la cantidad que alcanza el intestino grueso es muy poca y además no se metaboliza completamente. Es un poliol de cuatro carbonos obtenido por fermentación natural a partir de diferentes azúcares (Haji, 2009) y puede encontrarse en alimentos como el melón, uva, pera, vino, salsa de soja, o sake (Perko \&DeCock, 2006). Tiene un poder edulcorante del $60-80 \%$ respecto al del azúcar (Goossens \& Roeper, 1994) y su aporte calórico es menor a $0.5 \mathrm{Kcal} / \mathrm{g}$ (Oku \& Noda, 1990). En cuanto a estudios de toxicidad, se estima que una dosis de $1 \mathrm{~g} / \mathrm{Kg}$ de peso corporal no produce efectos adversos en el organismo (Tetzloff et al. 1996). Por otro lado, se trata de un edulcorante apropiado para adicionarlo en alimentos destinados a personas diabéticas, ya que no altera los niveles de insulina ni azúcar en sangre (Noda et al. 1994). El eritritol juega un papel similar al del azúcar en productos de bollería, por lo que se considera un buen sustituto en estos casos (Haji 2009).

\subsubsection{Tagatosa}

Es un monosacárido parecido a la fructosa y con un poder edulcorante del $92 \%$ respecto al azúcar. El aporte calórico de la tagatosa es de $1.4 \mathrm{Kcal} / \mathrm{g}$ (Levin, 2002). Se considera un ingrediente funcional debido a que se metaboliza parcialmente y la parte no absorbida ( $80 \%$ de la ingesta) fermenta en el colon, donde ejerce funciones de fibra soluble, favoreciendo la proliferación de bacterias ácido lácticas y de la especie Lactobacillus (PetersenSkytte, 2006). 


\subsection{Edulcorantes sin función de agente de carga}

En productos de bollería, este grupo de edulcorantes se tienen necesariamente que combinar con otro compuesto que aporte las funciones de agente de carga, ya que la única función que cumplen es endulzar el producto.

Los edulcorantes intensos artificiales aportan mucho más dulzor del que aporta el azúcar. Lo más habitual es reemplazar el azúcar de la formulación por un edulcorante intenso combinado con un agente de carga, como por ejemplo algún tipo de fibra, o un poliol.

A continuación se detallan las características de algunos de los edulcorantes intensos.

Sucralosa. Su poder edulcorante es 600 veces el poder edulcorante del azúcar debido a la combinación de los grupos hidroxilo y halógeno que posee en su estructura molecular y no aporta ninguna caloría (Figura 3). Es térmicamente estable, por lo que se considera adecuado para productos que sufran calentamiento como lo son los productos de bollería (Barndt \& Jackson, 1990; Knight, 1994). Por otro lado, la sucralosa cumple con las funciones de cristalización y dulzor del azúcar, pero no con las propiedades estructurales.

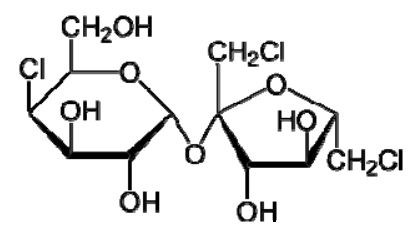

Figura 3. Estructura molecular de sucralosa

Stevia. Es un glucósido catalogado como edulcorante intenso natural que se extrae mediante disolución con agua a partir de partes de la planta stevia ssp. Stevia es 300 veces más dulce que el azúcar y no aporta calorías. En la actualidad en la Unión Europea no se permite su uso en productos de panadería/bollería (Kroyer, 2010; Zahn et al., 2012).

Acesulfamo K. Es la sal de potasio del acesulfamo. Es 200 veces más dulce que el azúcar y no aporta calorías. El dulzor se percibe rápidamente y no 
tiene sabor residual. Es soluble en agua y relativamente estable a la temperatura ya que se descompone a partir de $225^{\circ} \mathrm{C}$, por lo que es adecuado para incorporarlo en productos horneados que se desarrollen por debajo de dicha temperatura (Haber et all., 2006).

Aspartamo y Neotamo. El aspartamo se obtiene combinando 2 aminoácidos (fenilalanina y acido aspártico) mediante un enlace metil éster. Su poder edulcorante es de 180-200 veces el del azúcar (O’Donnell, 2006). E neotamo es un derivado del aspartamo. Es 8000 veces más dulce que el azúcar y no proporciona sabor amargo ni metálico. Al igual que el aspartamo, el neotamo es soluble en agua, y es sensible a la temperatura y al $\mathrm{pH}$, por lo que sólo se aplica en productos ácidos que ya no tengan que sufrir un proceso de cocción (O’Donnell, 2006). Estos edulcorantes no se pueden aplicar en las masas de los productos que necesiten un proceso de horneado.

Sacarina y Ciclamato. Son edulcorantes artificiales obtenidos por la industria mediante una serie de reacciones químicas. El poder edulcorante de la sacarina es 300 veces superior al del azúcar y el del ciclamato 30 veces superior (Giannuzzi \& Molina-Ortiz, 1995). Se caracterizan por tener un regusto metálico y amargo (DuBois, 2006). Aunque se pueden utilizar en productos de bollería únicamente con la función de edulcorante, su principal uso se localiza en la industria de bebidas y como edulcorante de mesa.

\subsection{Sustancias con función únicamente de agente de carga.}

Existe una gran variedad de sustancias que se pueden utilizar como sustitutos del azúcar debido a sus características de agente de carga. Estas sustancias no aportan sabor dulce al producto aunque, debido a su naturaleza carbonatada, pueden considerarse ligeramente dulces. No obstante, al ser mucho menos dulces que el azúcar, se recomienda combinarlos con un edulcorante intenso.

Estos ingredientes son por lo general higroscópicos y, al igual que el azúcar, son capaces de aportar viscosidad a la masa, con lo cual, se favorece 
la incorporación de aire durante el batido. Así mismo también afectan al proceso de gelatinización del almidón.

Las características de algunos de los agentes de carga de este grupo son las siguientes.

Polidextrosa. Es un polímero entrecruzado donde predominan enlaces glucosídicos 1,6, formados a partir de la fusión de monómeros de D-glucosa en presencia de pequeñas cantidades de sorbitol y acido cítrico (Belitz \& Grosch, 1997a). La polidextrosa es un agente de carga, ya que es un ingrediente capaz de imitar las funciones estructurales que tiene el azúcar en los alimentos (Torres \& Thomas, 1981). Al igual que muchos otros sustitutos de azúcar, la polidextrosa tiene menor contenido calórico $(1 \mathrm{Kcal} / \mathrm{g})$ y es apta para personas con diabetes ya que no eleva la glucemia y, por tanto, no produce cambios en la demanda de insulina del organismo (Torres \& Thomas, 1981; Roberfroid \& Slavin, 2000).

Inulina. Está compuesta por un número variable de unidades de fructosa (entre 2 y 60 ) unidas por enlace $\beta(2-1)$ y habitualmente una unidad de glucosa situada al final de la cadena. Se considera fibra alimentaria, ya que durante la digestión la molécula se metaboliza parcialmente, aportando únicamente $1,5 \mathrm{Kcal} / \mathrm{g}$ y en el tramo del intestino grueso es metabolizada por la flora bacteriana, dando lugar a la formación de compuestos como ácido butírico, dióxido de carbono, hidrógeno y metano. La formación de estos compuestos hace que pueda producir flatulencias. En función de su tamaño la inulina se puede utilizar como sustituta de azúcar o de grasa. Para su aplicación como sustituta de azúcar, se utiliza inulina de cadena corta, que tiene un ligero sabor dulce y simula las propiedades funcionales del azúcar (Devereux et al., 2003; Zahn et al., 2010).

\section{Sustitutos de grasa en productos de bollería.}

Los sustitutos de grasa son sustancias que, además de aportar menor contenido calórico al producto, cumplen con algunas de las funciones de la 
grasas. Los sustitutos de grasa comúnmente aplicados en magdalenas y bizcochos son aquellos basados en hidratos de carbono, ya que son los que proporcionan mejores propiedades organolépticas (Bath et al., 1992). Estos sustitutos son similares a las grasas en sus propiedades y pueden influir sobre la viscosidad, cremosidad y sabor en boca (Gómez, 2008). El principal problema del reemplazo de la grasa en este tipo de productos es que los ingredientes sustitutos no cubren todas las funciones de la grasa, por lo que es complicado obtener bizcochos tipo magdalenas y comúnmente se obtienen bizcochos tipo soletilla.

\subsection{Hidratos de carbono.}

Este grupo de ingredientes son sustitutos de grasa basados en hidratos de carbono. Una de las principales características es que absorben agua formando un gel que puede actuar como las grasas y cumplir con algunas de sus funciones.

Almidones. Por lo general, los almidones se utilizan como parte de mezclas comerciales basados en mezclas de proteínas, hidrocoloides y almidones. Entre los almidones más utilizados en productos de bollería como magdalenas o bizcochos, se encuentran el almidón modificado de maíz, el almidón pregelatinizado de maíz o el almidón de arroz (Pong et al., 1991; Kim et al., 2001; Bath et al., 1992).

Maltodextrinas. La sustitución de la grasa por maltodextrinas reduce la viscosidad de la masa y afecta negativamente a la retención de aire durante el horneado. Por esta razón, no es recomendable realizar un reemplazo de toda la grasa del producto ya que puede suponer una perdida de volumen del producto final. No obstante, es posible evitar o minimizar esta pérdida de volumen utilizando ciertos emulsionantes, como mono y digliceridos (Khalil, 1998; Lakshminarayan et al., 2006) o amilodextrinas (Kim et al., 2001; Kim et al., 2001).

Dextrinas. Se han utilizado dextrinas obtenidas a partir de almidón como sustituto de grasa. Por ejemplo, el producto comercial Nutriose ${ }^{\circledR}$ se 
corresponde con un tipo de dextrina considerada como fibra soluble, que se obtiene a partir del almidón de maíz o de trigo con la característica de que está parcialmente hidrolizada. El $75 \%$ de la cantidad ingerida no sufre acción enzimática en el intestino delgado, por lo que fermenta sólo al llegar al intestino grueso, ejerciendo su acción de fibra (Van den Heuvel et al. 2004). Es un ingrediente interesante capaz de ejercer las funciones que tiene la grasa y que no se ha estudiado su aplicación en productos de bollería.

\subsection{Fibras.}

Las fibras pueden desarrollar alguna de las funciones de la grasa y además aportan un valor añadido al producto final. Tradicionalmente en bollería la adición de fibras se ha realizado como ingrediente sustituto de harina o como ingrediente adicional además de los ya incluidos en la formulación.

Fibra de melocotón. Se ha utilizado en magdalenas (Grigelmo-Miguel et al., 2001), obteniendo un producto con menor contenido calórico, rico en fibra dietética, con mayor contenido en humedad, proteínas, minerales, con mayor dureza y masticabilidad y de un color más oscuro que las magdalenas control. No obstante, no se encontraron diferencias en aceptabilidad entre la formulación control y la formulación con un $4 \%$ de fibra.

Fibra de cacao. Es un tipo de fibra que hasta el momento no ha sido utilizado como sustituto de grasa en productos de bollería. Se trata de un producto obtenido por tratamiento enzimático de la cáscara de cacao, subproducto importante en la industria del cacao. Se ha catalogado como fibra dietética con una carga considerable de fracción insoluble, además de contener cantidades interesantes de compuestos antioxidantes (Lecumberi et al., 2007).

$\beta$-Glucanos. Son polisacáridos lineales formados por unidades de Dglucopiranosa unidos por enlaces $\beta-1,3$ y $\beta-1,4$. Se encuentran de forma natural en el salvado de los cereales, sobre todo en la avena y cebada y en menor concentración en el trigo y centeno, en la pared celular de las levaduras y en ciertas bacterias y hongos. Su principal característica es que en disolución aumentan considerablemente la viscosidad del medio (Belitz \& Grosch, 1997b). 
Están catalogados como fibra dietética y se consideran ingredientes beneficiosos para la salud, ya que disminuyen el colesterol en sangre, reducen la respuesta de glucosa e insulina y reducen el riesgo de sufrir obesidad, enfermedades coronarias, trastornos gastrointestinales y cáncer de colon. Han sido aplicados en diferentes productos de bollería y, especialmente, en magdalenas se ha visto que una sustitución del $20 \%$ del contenido graso no produce pérdidas de calidad (Kalinga \& Mishra, 2009; Lee et al., 2005).

Inulina. Se trata de polímeros de diferentes longitudes formados por unidades de fructosa unidas mediante un enlace glucosídico $\beta$ (2-1). Como ya se ha comentado anteriormente, dependiendo de la longitud de la cadena, la inulina tiene unas funciones u otras. Para el caso de reemplazo de grasa, la inulina más adecuada es la de cadena larga, ya que no modifica el sabor del alimento (no aporta dulzor) y tiene una textura y palatabilidad parecida a la de la grasa. Además, los polímeros no son hidrolizados por las enzimas humanas por lo que se ha catalogado como fibra dietética (Devereux et al., 2003; Zahn et al., 2010).

\subsection{Hidrocoloides y emulsionantes.}

Los hidrocoloides se han utilizado para reemplazar grasa por su capacidad de absorber agua, que hace que confieran estructura. Es habitual el uso aislado de goma xantana o de una combinación de goma xantana y goma arábiga (Jia et al., 2008), de goma guar y de carboximetilcelulosa (CMC) (Kaur et al., 2000).

El empleo de emulsionantes permite añadir menor cantidad de grasa al producto sin necesidad de reemplazarla con otro sustituto, ya que reducen la tensión superficial produciendo un aumento en la efectividad de las funciones de la grasa, sobre todo mejorando la textura y el volumen. Así, existen estudios en los que se reemplaza la grasa con algún sustituto de la familia de los hidratos de carbono en combinación con emulsionantes (Khalil, 1998). Como ejemplos de emulsionantes empleados en productos tipo magdalenas encontramos monoglicéridos, diglicéridos, monoestearato de sorbitán o de 
glicerol, ésteres de poliglicerol y polisorbato (Kaur et al., 2000; Conforti \&Smith, 1998; Khalil, 1998; Bath et al., 1992; Kamel \& Rasper, 1988). 


\section{Bibliografía.}

Baeva MR, Terzieva VV \& Panchev IN (2003) Structural development of sucrose-sweetened and sucrose-free sponge cakes during baking. Nahrung/ Food 47 (3), 154-160.

Barndt RL \& Jackson G (1990) Stability of sucralose in baked goods. Food Technology 44 (1), 62-66.

Bath DE, Shelke K \& Hoseney RC (1992) Fat replacers in high-ratio layer cakes. Cereal Foods World 37 (7), 495-500.

Beesley PM (1995) Sugar functionality reviewed. Food Technology International Europe, 87-89.

Belitz HD \& Grosch W (1997a) Azúcar, azúcares-alcohol y productos azucarados. En: Química de los alimentos (págs. 923-956) Editado por: HD Belitz \& W Grosch. Acribia SA (Zaragoza).

Belitz HD \& Grosch W (1997b) Cereales y derivados. En: Química de los alimentos (págs. 725-795). Editado por: HD Belitz \& W Grosch. Acribia SA (Zaragoza).

Bond M \& Dunning N (2006) Xylitol. En: Sweeteners and sugar alternatives in food technology (págs. 295-317). Editado por: Helen Mitchell. Blackwell Publishing Ed. (Oxford).

Bornet FRJ (1994) Undigestible sugars in food products. The American Journal of Clinical Nutrition 59 (suppl), 763S-9S.

Conforti FD \& Smith PM (1998) Effects of selected emulsifiers, enzymes and a carbohydrate-based fat substitute on physical and sensory characteristics in a low-fat muffin. Journal of Consumer Studies \& Home Economics 22, 91-96.

Conforti FD (2006) Cake manufacture. En: Bakery products: Science and Technology (págs. 393-410). Editado por: Y.H. Hui. Blackwell Publishing Ed. (Oxford). 
Devereux HM, Jones GP, McCormack L \& Hunter WC (2003) Consumer acceptability of low fat foods containing inulin and oligofructose. Journal of Food Science 68, 1850-1854.

DuBois GE (2006) Saccharin and cyclamate. En: Sweeteners and sugar alternatives in food technology (págs. 105-129). Editado por: Helen Mitchell. Blackwell Publishing Ed. (Oxford).

Giannuzzi L \& Molina-Ortiz SE (1995) Edulcorantes naturales y sinteticos: aplicaciones y aspectos toxicologicos. Acta Farmaceutica Bonaerense $14,119-131$.

Gómez M (2008) Low-sugar and low-fat sweet goods. En: Food engineering aspects of baking sweets goods. Editado por: S Gülüm Sumnu \& S Sahin. Boca Raton: CRC.

Goossens J \& Roeper H (1994) Erythritol: a new sweetener. Food Science \& Technology Today 8 (3), 144-148.

Grigelmo-Miguel N, Carreras-Boladeras E \& Martin-Belloso O (2001) Influence of the addition of peach dietary fiber in composition, physical properties and acceptability of reduced-fat muffins. Food Science and Technology International 7 (5), 425-431.

Haber B, von Rymon Lipinski GW \& Rathjen S (2006). Acesulfame K. En: Sweeteners and sugar alternatives in food technology (págs. 65-83). Editado por: Helen Mitchell. Blackwell Publishing Ed. (Oxford).

Haji F (2009) Erythritol: a natural innovation. Agro Food Industry Hi-tech 20 (3), 36-37.

INE Instituto Nacional de Estadística (2006) Encuesta nacional de salud. Ministerio de Sanidad y Consumo.

INE Instituto Nacional de Estadística (2012) Mujeres y hombres en España 2012. Ministerio de Sanidad, Servicios Sociales e Igualdad.

Jia C, Kim YS, Huang W \& Huang G (2008) Sensory and instrumental assessment of Chinese moon cake: Influences of almond flour, maltitol syrup, fat, and gums. Food Research International 41, 930-936. 
Kalinga D \& Mishra VK (2009) Rheological and physical properties of low fat cakes produced by addition of cereal b-glucan concentrates. Journal of Food Processing and Preservation 33, 384-400.

Kamel BS \& Rasper VF (1988) Effects of emulsifiers, sorbitol, polydextrose and crystalline cellulose on the texture of reducedcalorie cakes. Journal of Texture Studies 19 (3), 307-320.

Kaur A, Singh G \& Kaur H (2000) Studies on use of emulsifiers and hydrocolloids as fat replacers in baked products. Journal of Food Science and Technology-Mysore 37, 250-255.

Khalil AH (1998) The influence of carbohydrate-based fat replacers with and without emulsifiers on the quality characteristics of low fat cake. Plant Foods for Human Nutrition 52, 299-313.

Kim HY, Yeom HW, Lim HS \& Lim ST (2001) Replacement of shortening in yellow layer cakes by corn dextrins. Cereal Chemistry 78, 267-271.

Knight I (1994) The developenemtand applications of sucralose, a newhighintensity sweetener. Canadian Journal of Physiology and Pharmacology 72, 435-439.

Kroyer G (2010) Stevioside and Stevia-sweetener in food: application, stability and interaction with food ingredients. Journal für Verbraucherschutz und Lebensmittelsicherheit 5 (2), 225-229.

Lakshminarayan SM, Rathinam V \& KrishnaRau L (2006) Effect of maltodextrin and emulsifiers on the viscosity of cake batter and on the quality of cakes. Journal of the Science of Food and Agriculture 86, 706-712.

Lecumberri E, Mateos R, Izquierdo-Piulido M, Rupérez P, Goya L \& Bravo L (2007) Dietary fibre composition, antioxidant capacity and physicochemical properties of a fibre-rich product from cocoa (Theobroma cocoa L.). Food Chemistry 104, 948-954.

Lee S, Kim S \& Inglett GE (2005) Effect of shortening replacement with oatrim on the physical and rheological properties of cakes. Cereal Chemistry 82 , 120-124. 
McNutt K \& Sentko A (1996) Sugar replacers. A growing group of sweeteners in the United States. Nutrition Today 31, 255-261.

Ministerio de Medio Ambiente y Medio Rural y Marino (2006) Productos novedosos. OCDA.

Ministerio de Medio Ambiente y Medio Rural y Marino (2008) Consumo alimentario en España.

Noda K, Nakayama K \& Oku T (1994) Serum glucose and insulin levels and erythritol balance after oral administration of erythritol in healthy subjects. European Journal of Clinical Nutrition 48, 286-292.

O'Donnell K (2006) Aspartame and neotame. En: Sweeteners and sugar alternatives in food technology (págs. 86-100). Editado por: Helen Mitchell. Blackwell Publishing Ed. (Oxford).

Oku T \& Noda K (1990) Influence of chronic ingestion of newly developed sweetener erythritol on growth and gastrointestinal function of the rats. Nutrition Research 10 (10), 987-996.

Olinger PM \& Velasco VS (1996) Opportunities and advantages of sugar replacement. Cereal Foods World 41 (3), 110-117.

Perko R \& DeCock (2006) Erythytol. En: Sweeteners and sugar alternatives in food technology (págs. 151-175). Editado por: Helen Mitchell. Blackwell Publishing Ed. (Oxford).

Petersen-Skytte U (2006) Tagatose. En: Sweeteners and sugar alternatives in food technology (págs. 262-292). Editado por: Helen Mitchell. Blackwell Publishing Ed. (Oxford).

Psimouli V \& Oreopoulou V (2012) The effect of alternative sweeteners on batter rheology and cake properties. Journal of the Science of Food and Agriculture 92 (1), 99-105.

Pong L, Johnson JM, Barbeau WE \& Stewart DL (1991) Evaluation of alternative fat and sweetener systems in cupcakes. Cereal Chemistry $68,552-555$.

Roberfroid M \& Slavin J (2000) Nondigestible oligosaccharides. Critical Reviews in Food Science and Nutrition 40 (6), 461-480. 
Ronda F, Gómez M, Blanco CA \& Caballero PA (2005) Effects of polyols and nondigestible oligosaccharides on the quality of sucrose-free sponge cakes. Food Chemistry 90 (4), 549-555.

Sandrou DK \& Arvanitoyannis IS (2000) Low-fat/calorie foods: current state and perspectives. Critical Reviews in Food Science and Nutrition 40 (5), 427447.

Tetzloff W, Dauchy F, Medimagh S, Carr D, \& Bär A (1996) Tolerance to subchronic, high-dose ingestion of erythritol in human volunteers. Regulatory Toxicology and Pharmacology 24, S286-295.

Torres A \& Thomas RD (1981) Polydextrose and its applications in food. Food Technology 35 (7), 44-49.

Trallero R \& Humanes A (2004) Dietas hipocalóricas. En: Nutrición y dietética clínica (págs. 155-170). Editado por: Salas-Salvadó J, Bonada A, Trallero R \& Saló ME. Masson, S.A.

Van den Heuvel EGHM, Wils D, Pasman WJ, Bakker M, Saniez MH \& Kardinaal AFM (2004) Short-term digestive tolerance of different doses of nutriose FB, a food dextrin, in adult men. European Journal of Clinical Nutrition 58, 1046-1055.

Varela G, Ruiz-Roso B \& Fernández-Valderrama C (1993) Bollería, ingesta grasa y niveles de colesterol en sangre. Publicaciones serie "Divulgación" $\mathrm{n}^{\circ} 14$.

Young H (2006) Lactitol. En: Sweeteners and sugar alternatives in food technology (págs. 205-221). Editado por: Helen Mitchell. Blackwell Publishing Ed. (Oxford).

Zahn S, Pepke F \& Rohm H (2010) Effect of inulin as a fat replacer on texture and sensory properties of muffins. International Journal of Food Science and Technology 45, 2531-2537.

Zahn S, Forker A, Krügel L, Rohm H (2013) Combined use of rebaudioside A and fibres for partial sucrose replacement in muffins. LWT - Food Science and Technology 50 (2),695-701. 
Zumbé A, Lee A \& Storey D (2001) Polyols in confectionery: the route to sugarfree, reduced sugar and reduced calorie confectionery. British Journal of Nutrition 85, Suppl. 1, S31-S45. 
OBJETIVOS 



\section{OBJETIVOS}

\section{OBJETIVO GENERAL y OBJETIVOS PARCIALES}

El objetivo general de la presente tesis doctoral fue evaluar el efecto del reemplazo de azúcar o grasa por distintos reemplazantes sobre las propiedades estructurales y la calidad final en magdalenas, como representantes de producto de bollería de alta humedad.

Para ello se desarrollaron los siguientes objetivos parciales:

- $\quad$ Seleccionar una formulación "control" tradicional poniendo a punto el proceso de elaboración de una masa batida cruda que permita su correcta manipulación antes del enmoldado y cocción.

- Evaluar la influencia en el comportamiento de flujo de las masas al reemplazar el azúcar y la grasa por distintos reemplazantes.

- Estudiar el efecto de los distintos reemplazantes sobre las propiedades de viscoelasticidad de las masas crudas y durante su calentamiento.

- Estudiar el proceso de gelatinización de almidón mediante calorimetría diferencial de barrido y el efecto de los reemplazantes sobre el mismo.

- Desarrollar la metodología para la evaluación instrumental de los principales parámetros texturales de las magdalenas desarrolladas haciendo especial hincapié en aquéllos que se asocien a la "frescura" característica del producto recién horneado. Medir el efecto de los reemplazantes sobre dichos cambios.

- Valorar otras características del producto final que influyen en su aceptabilidad como son la apariencia, altura, volumen y distribución de celdas de aire en la miga.

- Conocer los descriptores de los atributos sensoriales que mejor definan las principales características del producto tradicional y 
aquellos nuevos atributos que puedan surgir en los productos reformulados con menor contenido en azúcar o grasa utilizando un panel de catadores entrenados.

- Evaluar la aceptación de los nuevos productos en las características de aspecto, textura, aroma y sabor utilizando un panel de consumidores.

- Integrar los resultados obtenidos con las distintas metodologías empleadas para conocer el efecto del reemplazo de azúcar y grasa sobre la estructura de la masa batida y la magdalena final y su repercusión en los parámetros de calidad. 
ESTRUCTURA DE LA TESIS DOCTORAL 



\section{ESTRUCTURA DE LA TESIS DOCTORAL}

El trabajo de investigación realizado ha dado lugar a cinco publicaciones científicas, cuyo contenido se presenta en los distintos capítulos de la presente tesis doctoral. Las referencias de dichas publicaciones y el capítulo en el que aparecen, son los siguientes:

Capítulo 1. Martínez-Cervera, S., Sanz, T., Salvador, A. y Fiszman, S.M. (2012). Rheological, textural and sensorial properties of lowsucrose muffins reformulated with sucralose/polydextrose. LWT-Food Science and Technology 45, 213-220.

Capítulo 2. Martínez-Cervera, S., de la Hera, E., Sanz, T., Gómez, M. y Salvador, A. (2012). Effect of using erythritol as a sucrose replacer in making Spanish muffins incorporating xanthan gum. Food Bioprocess and Technology 5 (8), 3203-3216.

Capítulo 3. Martínez-Cervera, S., Salvador, A. y Sanz, T. Comparison of different polyols as total sucrose replacers in muffins: thermal, rheological, texture and acceptability properties. Food Hydrocolloids (Enviado).

Capítulo 4. Martínez-Cervera, S., Salvador, A., Muguerza, B., Moulay, L. y Fiszman, S.M. (2011). Cocoa fibre and its application as a fat replacer in chocolate muffins. LWT-Food Science and Technology 44, 729-736.

Capítulo 5. Martínez-Cervera, S., de la Hera, E., Sanz, T, Gómez, M. y Salvador, A. (2012). Effect of nutriose on rheological, textural and sensorial characteristics of Spanish muffins. Food Bioprocess and Technology DOI 10.1007/s11947-012-0939-X

La tesis se ha estructurado en dos grandes bloques.

El primer bloque, que engloba los tres primeros capítulos, hace referencia al estudio de la función que ejerce el azúcar en la magdalena y los 
cambios en las propiedades físicas que se producen con el reemplazo parcial o total de éste por diferentes edulcorantes.

En el primer capítulo se estudia el efecto que tiene el reemplazo del azúcar por una mezcla de un agente de carga (polidextrosa) y un edulcorante intenso (sucralosa) sobre la calidad del producto. Se analizaron las propiedades reológicas de la masa así como la capacidad de incorporación de aire durante el amasado y la estabilidad de las burbujas en la masa. En cuanto al producto final, se estudió la altura de las magdalenas, la estructura de la miga, la textura de la miga y el color tanto de la miga como de la corteza. Por último, se realizó un análisis sensorial de aceptación de las magdalenas cuando se sustituyó parcial o totalmente el azúcar.

En el segundo capítulo se estudió de qué manera afecta la eliminación total del azúcar a las propiedades reológicas de la masa y a la textura de las magdalenas. Además, se abordó en mayor profundidad el papel que juega el azúcar en la estructura interior del producto (miga). Paralelamente se evaluó la utilización de eritritol, como poliol de nueva generación con un perfil metabólico único, como sustituto de azúcar.

Finalmente, en el tercer capítulo, se comparó el comportamiento de diferentes polioles (sorbitol, maltitol, isomaltitol y eritritol) en el reemplazo total de azúcar sobre las propiedades térmicas, reológicas, de textura y sensoriales de las magdalenas. En este caso, se prestó especial atención al estudio del proceso de gelatinización del almidón tanto desde el punto de vista reológico como térmico.

En el segundo bloque, que engloba los dos últimos capítulos, el objetivo principal fue entender el papel que desempeña la grasa en las magdalenas, y de qué manera se ven afectadas las características de calidad de las mismas cuando esta grasa se reemplaza total o parcialmente.

Así, en el cuarto capítulo se estudió el efecto del reemplazo de diferentes porcentajes de grasa por fibra de cacao. Esta fibra es un subproducto de la industria del chocolate que tiene una alta concentración de 
fibra insoluble así como de compuestos antioxidantes por lo que se planteó su estudio como sustituto de grasa a la vez que podría servir para enriquecer el producto con fibra. Además, y para un mejor entendimiento de las propiedades que aporta la fibra de cacao, se realizó un estudio sensorial descriptivo para determinar si aparecen nuevos atributos sensoriales al reemplazar parcialmente la grasa por dicha fibra.

Por último, el quinto capítulo de la presente tesis estudia el efecto que tiene el reemplazo de grasa en las magdalenas por una dextrina parcialmente hidrolizada que también tiene funciones de fibra (Nutriose $\left.{ }^{\circledR}\right)$. Al igual que en los capítulos anteriores, se determinaron las propiedades reológicas, texturales y sensoriales de los productos. Así mismo, se estudiaron los cambios en las propiedades térmicas tanto de la masa como de la magdalena final. 


\title{
CAPÍTULO 1
}

\author{
RHEOLOGICAL, TEXTURAL AND SENSORIAL \\ PROPERTIES OF LOW-SUCROSE MUFFINS \\ REFORMULATED WITH SUCRALOSE/POLYDEXTROSE \\ Martínez-Cervera S, Sanz T, Salvador A \& Fiszman SM \\ LWT-FoOd SCIENCE AND TECHNOLOGY (2012), 45, 213-220.
}





\begin{abstract}
A study was made of the structure, texture, appearance, colour and consumer sensory analysis of low-sucrose muffins in which the sucrose had been totally or partially replaced $(25 \%, 50 \%$ and $75 \%)$ by a sucralose:polydextrose mixture (1:1012). The structural characteristics of the muffin batters and of the baked muffins were studied through rheometry, microscopy, image analysis and texture analysis. The replacement of sucrose decreased the viscosity, viscoelasticiy and specific gravity of the raw muffin batter. The evolution of the batter's viscoelastic properties during heating reveals a decrease in the thermosetting temperature with sucrose replacement. These changes in the batter were associated with a muffin with less height, hardness, springiness, cohesiveness, chewiness and resilience and fewer air cells than the control. For $50 \%$ sucrose replacement, the appearance, colour, texture, flavour and sweetness and general acceptability were similar to those of the control. Significantly less acceptable muffins were obtained with $100 \%$ sucrose replacement.
\end{abstract}

Keywords: sucralose; polydextrose; muffins; rheology. 


\section{Introduction}

The growing consumer interest in health and its relationship with diet has led to a considerable rise in the demand for low sucrose and low fat products.

Muffins are sweet, high-calorie baked products which are highly appreciated by consumers due to their good taste and soft texture. Muffin batter is a complex fat-in-water emulsion composed of an egg-sucrose-water-fat mixture as the continuous phase and bubbles as the discontinuous phase in which flour particles are dispersed. Muffins are characterized by a typical porous structure and high volume which confer a spongy texture. To obtain such a final structure, a stable batter lodging many tiny air bubbles is required.

Sucrose performs multiple functions in this kind of baked product. Besides contributing to the sweet taste, sucrose provides a considerable part of the bulk in batters or doughs, helps baked goods stay moist, and limits the swelling of starch, which helps to create a finer texture. Under nonacidic conditions, it also contributes to the browning of the crust. One important role it plays is to delay starch gelatinization and protein denaturation temperatures during cake baking so that the air bubbles can be properly expanded by the carbon dioxide and water vapour before the batter sets (Rosenthal, 1995). As a result, the cake structure is highly aerated and voluminous (Baeva, Terzieva \& Panchev, 2003). Furthermore, sucrose promotes fat-crystal aggregates, thus enhancing air entrapment and the stabilization of air bubbles during baking (Beesley, 1995).

Due to the complex structural functionality of sucrose in baked products, obtaining good quality low-sucrose products is a difficult task. Sucrose replacement in baked products needs to consider both the sweetness and the bulking effect of sucrose.

Sucralose (SC) (1,6-dichloro-1,6-dideoxy- $\beta$-D-dructofuranosyl-4-chlorodeoxy- $\alpha$-D-galactopyranoside) is a zero-calorie sweetener, which is 600 times sweeter than sucrose. SC is heat-stable, retaining its sweetness, and could 
therefore be considered a suitable sweetener for bakery products (Barndt \& Jackson, 1990) (Knight, 1994). Although SC provides the sweetness and crystallization properties of sucrose, it has the disadvantage that it cannot mimic the structural contribution of sucrose to baked products. As a result, SC has to be combined with other substances which provide this functionality. Lin \& Lee (2005) studied the effect of replacement of sucrose by a mixture of sucralose and a type of indigestible dextrin in chiffon cakes obtaining good results in physical and sensory properties in samples with less than $50 \%$ replacement.

Polydextrose (PD) is a bulking agent which mimics the structural functions of sucrose, other than sweetness and crystallization (Torres \& Thomas, 1981). PD has a very low calorie content $(1 \mathrm{kcal} / \mathrm{g})$. Since PD has been shown not to increase serum glucose values or create insulin demand in diabetics, it would appear to be a suitable component for special foods for diabetics (Torres \& Thomas, 1981) (Roberfroid \& Slavin, 2000).

PD has often been combined with high intensity sweeteners. Attia, ElSaid, Shehata \& Askar (1993) studied the effect of replacing sucrose with fructose, acesulfame-K or aspartame, with or without the addition of $P D$, on the physical properties of cakes. The results indicated that adding PD caused an improvement in textural properties. PD has also been employed alone to replace sucrose in bakery products. Hicsasmaz, Yazgan, Bozoglu \& Kaunas (2003) studied the effect of PD substitution on a high-ratio cake system; a higher sugar replacement level resulted in a decrease in crack-like cells and an increase in small sphere-like cells, causing a significant decrease in cake height. Ronda, Gómez, Blanco \& Caballero (2005) studied the effect on sponge cake volume, colour and texture properties of total replacement of sucrose by seven bulking agents, including PD. The results showed that xylitol-PD was a good option to replace sugar. There is no previous scientific research on sucrose substitution by a mixture of SC and PD in muffins. This study evaluated the suitability of a mixture of SC and PD to replace different percentages of sucrose in muffins. The properties of the muffin batters (rheology and microstructure) and of the muffins (texture, colour and sensory acceptability) 
were measured and conclusions about the structural features associated with sucrose replacement were drawn.

\section{Materials and Methods}

\subsection{Batter and muffin preparation}

Five muffin formulations were prepared by replacing part of the sucrose with polydextrose and sucralose (both from Tate \& Lyle, Mclntosh, Alabama) (1012:1). The samples were identified as control, 25\%PD-SC, 50\%PD-SC, 75\%PD-SC and 100\%PD-SC (Table 1). The muffin ingredients were wheat flour (Belenguer S.A., Spain. Information provided by the supplier: $\leq 15 \%$ moisture, $10 \%$ proteins), pasteurized liquid egg yolk and pasteurized liquid egg white (Ovocity, Spain), refined sunflower oil (Coosur S.A., Spain), whole milk (Puleva, Spain), sucrose (Azucarera Ebro, Spain), sodium bicarbonate (Martínez, Cheste, Spain), citric acid (Martínez, Cheste, Spain) and natural lemon peel.

The batter was prepared in a mixer (Kenwood Major Classic, UK), in which the egg whites were whisked for 2 minutes at top speed. The sucrose, PD and SC (depending on the formulation) were added and mixed in for 30 seconds more at top speed. The egg yolk, half the milk and the citric acid were then added and the mixer was set to speed 3 for 1 minute. The flour, sodium bicarbonate and natural lemon peel were added and the mixture was beaten for a further 1 minute at speed 3. Lastly, the mixer speed was increased to 4 , the rest of the milk was added and the oil was gradually dripped in. The mixture was beaten for 3 minutes at speed 4 until it was smooth.

The batter was poured into a dosing machine (Edhard Corp., Hackettstown, USA). With the aid of a weighing scale, the quantity of batter dispensed was adjusted to exactly $45 \mathrm{~g}$ in each $60 \mathrm{~mm}$ diameter x $36 \mathrm{~mm}$ high paper mould. 12 moulds were arranged in three rows of four on a baking tray and baked for 17 minutes at $175^{\circ} \mathrm{C}$ in an electric oven (Fagor Elegance $2 \mathrm{H}$ 114B, Guipúzcua, Spain) that had been preheated to this temperature for 10 
minutes. The oven, the tray and the tray position in the oven were identical in each case.

\begin{tabular}{|c|c|c|c|c|c|}
\hline $\begin{array}{l}\text { Ingredients } \\
\text { (g/100 g flour) }\end{array}$ & Control & $\begin{array}{l}25 \% \\
\text { PD-SC }\end{array}$ & $\begin{array}{l}50 \% \\
\text { PD-SC }\end{array}$ & $\begin{array}{l}75 \% \\
\text { PD-SC }\end{array}$ & $\begin{array}{l}100 \% \\
\text { PD-SC }\end{array}$ \\
\hline Flour & 100 & 100 & 100 & 100 & 100 \\
\hline Egg yolk & 26.92 & 26.92 & 26.92 & 26.92 & 26.92 \\
\hline Egg white & 53.85 & 53.85 & 53.85 & 53.85 & 53.85 \\
\hline Milk & 50 & 50 & 50 & 50 & 50 \\
\hline Sucrose & 100 & 75 & 50 & 25 & 0 \\
\hline Polydextrose & 0.00 & 24.97 & 49.95 & 74.93 & 99.90 \\
\hline Sucralose & 0.000 & 0.025 & 0.049 & 0.074 & 0.098 \\
\hline Oil & 46.15 & 46.15 & 46.15 & 46.15 & 46.15 \\
\hline Sodium bicarbonate & 3.96 & 3.96 & 3.96 & 3.96 & 3.96 \\
\hline Citric acid & 3.04 & 3.04 & 3.04 & 3.04 & 3.04 \\
\hline Natural lemon peel & 0.69 & 0.69 & 0.69 & 0.69 & 0.69 \\
\hline
\end{tabular}

The muffins were left to cool at room temperature for one hour on a rack in order to avoid moisture condensing on their undersurface. The twelve muffins baked on the same baking tray were packed in sets of six in two polypropylene bags $\left(\mathrm{O}_{2}\right.$ permeability at $23^{\circ} \mathrm{C}=1650 \mathrm{~cm} / \mathrm{m}^{2}$.day; water vapour permeability at $38{ }^{\circ} \mathrm{C}$ and $90 \%$ humidity $=9 \mathrm{~g} / \mathrm{m}^{2}$.day; thickness $\left.=65 \mu \mathrm{m}\right)$ and stored at $20^{\circ} \mathrm{C}$ for one day.

\subsection{Properties of the batter}

The specific gravity of the dough (SG) was measured as the ratio of the weight of a standard container filled with batter to that of the same container filled with water. Two replicates from different batches of each formula were measured. 
Dough bubbles were observed with a microscope (Nikon Eclipse 90i) using clear field mode. The micrographs were taken with a Nikon Digital Sight DS-5Mc cooled colour digital camera, using 40x magnification. Each formulation was prepared twice, on different days, and 4 replicates of each formula were photographed.

The rheological properties of the muffin batters were studied using an AR G2 controlled-stress rheometer (TA Instruments, Crawley, UK). The batters were all kept at $25^{\circ} \mathrm{C}$ for $60 \mathrm{~min}$ after batter preparation before the rheological test. The samples were allowed to rest in the measurement cell for a $25 \mathrm{~min}$ equilibration time. A $40 \mathrm{~mm}$ diameter plate-plate sensor geometry with a serrated surface and a $1 \mathrm{~mm}$ gap was employed. A continuous ramp at $25^{\circ} \mathrm{C}$ was applied and the apparent viscosity was measured as a function of shear rate over the $0.01-100 \mathrm{~s}^{-1}$ range for 5 minutes. Two replicates of each flow curve were run with samples prepared on different days. All the curves were adjusted to the Ostwald model:

$$
\eta=K \dot{\gamma}^{n-1}
$$

Where $\eta$ is the apparent viscosity, $\mathrm{K}$ is the consistency index, gamma dot is the shear rate and $\mathrm{n}$ is the flow index.

To simulate the effect of heating in the batter structure, temperature sweeps were performed from $25^{\circ} \mathrm{C}$ to $95^{\circ} \mathrm{C}$ at a heating rate of $1.0^{\circ} \mathrm{C} / \mathrm{min}$ and a strain amplitude of 0.0005 . The strain applied was selected to guarantee the existence of a linear viscoelastic response according to previous stress sweeps carried out at $25^{\circ} \mathrm{C}$ and $95^{\circ} \mathrm{C}$. Vaseline oil was applied to the exposed surfaces of all the samples. Two replicates from different batches of each formula were measured.

\subsection{Properties of the muffins}

The muffins were weighed before (W3) and after baking and cooling (W4) and the weight loss was calculated. Each formulation was prepared twice, on different days, and 7 muffins from each batch (fourteen determinations) were measured. 
The muffin height was measured with a calliper from the highest point of the muffin to the bottom of the paper mould after cooling for $1 \mathrm{~h}$ at room temperature. Seven replicates from each batch were measured.

A Konica Minolta CM-3500 spectrocolorimeter was used to measure the colour of the muffins. The results were expressed in accordance with the CIELAB system (D65 illuminant and $10^{\circ}$ viewing angle). The measurements were made with a $8 \mathrm{~mm}$ diameter diaphragm inset with optical glass. The parameters measured were $L^{*}\left(L^{*}=0\right.$ [black], $L^{*}=100$ [white] $), a^{*}\left(+a^{*}=\right.$ red $)$ and $b^{*}\left(+b^{*}=y e l l o w\right)$. The colour of the crust and crumb was measured at several points. Four muffins from each batch (eight determinations) were measured. The total colour difference $\left(\Delta \mathrm{E}^{*}\right)$ between the control sample and each of the muffins containing PD-SC was calculated as follows:

$$
\Delta \mathrm{E}^{*}=\left(\left(\Delta \mathrm{L}^{*}\right)^{2}+\left(\Delta \mathrm{a}^{*}\right)^{2}+\left(\Delta \mathrm{b}^{*}\right)^{2}\right)^{1 / 2}
$$

The instrumental texture measurements were made with a TA.XT.plus Texture Analyser (Stable Microsystems, Godalming, UK). Each formulation was prepared twice, on different days, and 4 muffins from each batch (eight determinations) were measured.

The muffins were cut horizontally at the height of the mould, the upper half was discarded and the $2.5 \mathrm{~cm}$-high lower halves were removed from the mould. A double compression test was performed to a height of $1.25 \mathrm{~cm}(50 \%$ compression) with a $75 \mathrm{~mm}$ diameter flat-ended cylindrical probe (P/75), at a speed of $1 \mathrm{~mm} / \mathrm{s}$ with a $5 \mathrm{~s}$ waiting time between the two cycles. The parameters obtained from the curves were hardness, springiness, cohesiveness, chewiness and resilience.

For bubble measurements, the muffins were cut on a horizontal plane at a distance of $2.5 \mathrm{~cm}$ from the base and images of the freshly cut surface of the crumb were captured using a flatbed scanner (HP 4300c, Hewlett Packard, USA). Image processing was performed using Image Pro-Plus 4.5 software (Media Cybernetics, USA). The images were converted to a 8 bit grey scale and segmented separately using a histogram-based segmentation that was defined 
individually for each image. The bubbles within an area of $0.04 \mathrm{~m}^{2}$ were counted. Two muffins from each batch (four determinations) were measured.

Sensory analysis was carried out using 60 consumers aged between 20 and 64 who consumed muffins on a twice- weekly basis. $14 \%$ of the consumers were male and $86 \%$ female. Each consumer tasted three muffins (control, $50 \%$ PD-SC and 100\%PD-SC), presented monadically at a single session following a balanced complete block experimental design. The muffins were coded with random three-digit numbers. The consumers rated the appearance, colour, texture, sweetness, flavour and overall acceptance of each muffin sample on a nine-point hedonic scale ranging from "dislike extremely" to "like extremely".

\subsection{Statistical analysis of the results}

One way-ANOVA was applied. Least significant differences were calculated by the Tukey test and the significance at $\mathrm{P}<0.05$ was determined. These analyses were performed using SPSS for Windows Version 12 (SPSS Inc., USA).

\section{Results and Discussion}

\subsection{Flow properties of the batters}

Batter viscosity is an important physical property as it is closely related to the final quality of an aerated baked product. Air incorporation and retention, bubble stability and the generation of convection currents in the batter during baking are dependent on the initial batter viscosity and on the evolution of bulk viscosity during heating.

The viscosity versus shear rate values revealed the shear thinning behaviour of all the muffin batters, in other words, the viscosity decreased as the shear rate increased. In the shear rate range studied, the results showed good fit to the Ostwald de Waele model. The consistency index $(\mathrm{K})$ and flow index $(n)$ values are shown in Table 2. For levels of sucrose replacement higher 
than $50 \%$, a slight but not significant decrease in $\mathrm{K}$ was found. The flow index values were significantly affected: as the level of sucrose replacement rose, an increase in $\mathrm{n}$ was found (values increasingly closer to 1), revealing a simpler structure with more nearly Newtonian behaviour (values of $n=1$ ).

Table 2. Specific gravity (SG) at $25^{\circ} \mathrm{C}$, consistency index (K) and flow behaviour index ( $n$ ) for muffin batters with increasing levels of polydextrose and sucralose mixture (PD-SC) replacing sucrose.

\begin{tabular}{|c|c|c|c|}
\hline Sample & $\mathrm{K}$ (Pa.s) & $n(1 / s)$ & SG (g/L) \\
\hline Control & $\begin{array}{l}17.87 a \\
(1.84)\end{array}$ & $\begin{array}{l}0.51 a b \\
(0.05)\end{array}$ & $\begin{array}{l}1.01 a \\
(0.00)\end{array}$ \\
\hline 25\%PD-SC & $\begin{array}{l}18.43 a \\
(1.97)\end{array}$ & $\begin{array}{l}0.49 a \\
(0.02)\end{array}$ & $\begin{array}{l}0.97 b \\
(0.01)\end{array}$ \\
\hline $50 \%$ PD-SC & $\begin{array}{l}17.94 a \\
(0.03)\end{array}$ & $\begin{array}{l}0.55 a b c \\
(0.01)\end{array}$ & $\begin{array}{l}0.92 \mathrm{c} \\
(0.01)\end{array}$ \\
\hline 75\%PD-SC & $\begin{array}{l}13.83 a \\
(1.41)\end{array}$ & $\begin{array}{l}0.62 \mathrm{bc} \\
(0.03)\end{array}$ & $\begin{array}{l}0.91 \mathrm{c} \\
(0.01)\end{array}$ \\
\hline 100\%PD-SC & $\begin{array}{l}13.29 a \\
(0.32)\end{array}$ & $\begin{array}{l}0.63 c \\
(0.01)\end{array}$ & $\begin{array}{l}0.90 \mathrm{c} \\
(0.00)\end{array}$ \\
\hline
\end{tabular}

Values in parentheses are standard deviations. Means in the same column without a common letter differ $(\mathrm{P}<0.05)$ according to the least significant difference multiple range test.

\subsection{Specific gravity and bubbles in muffin batter}

Specific gravity (SG) provides an indication of the total air holding capacity of the batter. Low SG values indicate good incorporation of air, yielding a higher final volume after baking; however, many other factors also affect this quality parameter (Frye \& Setser 1991). The SG values of the different muffin batters are shown in Table 2. A significant decrease in SG was found with sucrose replacement by the PD-SC mixture, indicating higher incorporation of air into the batter as sucrose was replaced. SG has also been found to decrease in sponge cakes on replacing sucrose with wheat starch, sorbitol and aspartame (Baeva, Terzieva \& Panchev, 2003).

As SG values do not provide information about bubble size or distribution, the batters were observed by light microscopy to obtain this information. The microphotographs obtained for the control, 50\% and 100\% sucrose replacement batters are shown in Figure 1. When sucrose was 
replaced by the PD-SC mixture, a change in bubble size was observed: the number of larger-diameter air bubbles decreased. This reduction in bubble size could be the consequence of the lower consistency of the sucrose-reduced batters, favouring bubble buoyancy. As the beating energy provided to all the batter formulations was the same, a lower viscosity may have allowed the larger air cells to coalesce and escape while retaining the small ones. Hanselmann \& Windhab (1999) also found that the air bubble size decreased in low viscosity systems compared with higher viscosity ones. In principle, a larger number of small gas nuclei in the batter is a positive factor for final quality, as it will favour the formation of tiny air cells that can enlarge during baking, which in turn favours height and volume gain.

Hicsasmaz, Yazgan, Bozoglu \& Kaunas (2003) found that the bubble population measuring $1 \times 10^{-10}$ and $1 \times 10^{-9} \mathrm{~m}^{2}$ (the most common size group in the total bubble population) increased progressively up to $95 \%$ of the bubble population for full sucrose replacement with PD; that is to say, the uniformity of the bubble size distribution in the raw batter increased.

These results indicated that PD substitution confined most of the bubbles to the normal size range yet also caused thinner batters. This even bubble size distribution effect of PD has been related to fat functionality support by PD. Similar results were found by the same research team (Kocer, Hicsasmaz, Bayindirli \& Katnas, 2007) for the batter of a high-ratio cake formulation in which sucrose was replaced by PD; polydextrose was described as having very good properties in distributing the gas phase into the batter by decreasing average bubble sizes and increasing bubble size uniformity with increased PD substitution.

The lower SG was associated with a decrease in heat exchange, especially during the initial baking steps. 
A
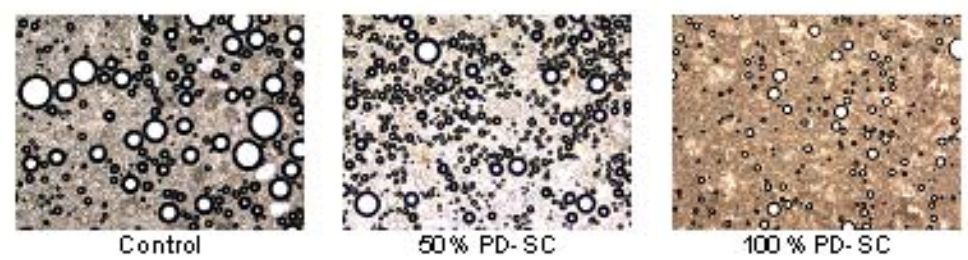

B
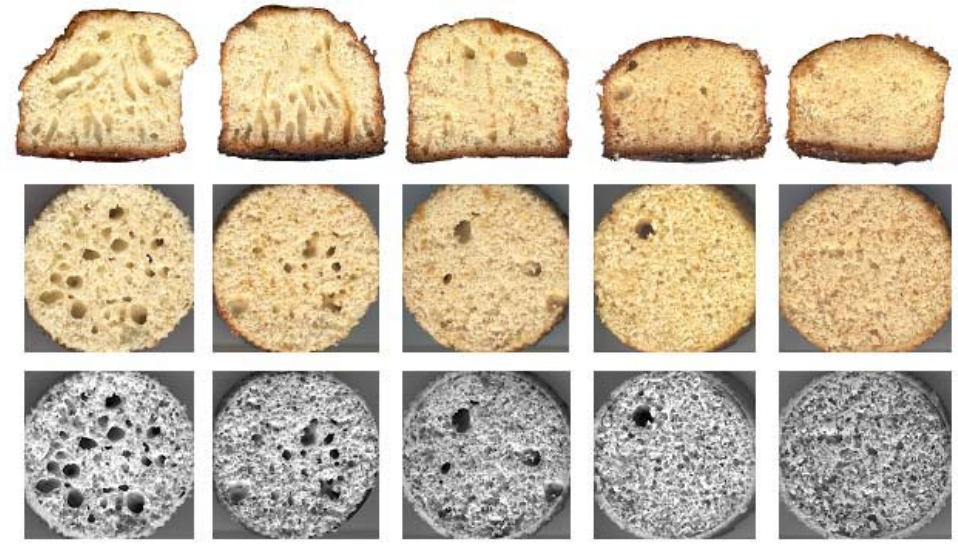

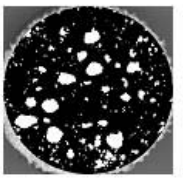

Control

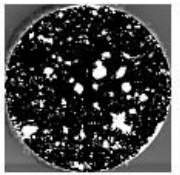

$25 \%$ PD-SC

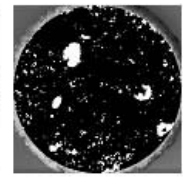

$50 \%$ PD-SC

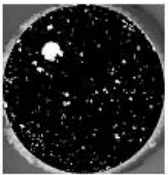

$75 \%$ PD-SC

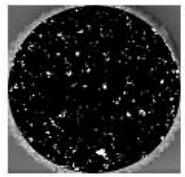

$100 \%$ PD-SC

Figure 1. Micrographs for the control batter and batters prepared with increasing quantities of polydextrose and sucralose (PD-SC) replacing sucrose (50\%PD-SC and 100\%PD-SC) obtained with light microscopy (A) and photographs of transversal and longitudinal sections of muffins prepared with increasing quantities of a polydextrose/sucralose mixture (B).

\subsection{Viscoelastic properties of the batter during heating}

In addition to the properties of the muffin batter, the structural changes that occur during baking are also determining factors in bubble formation and evolution and in the final baked product structure and texture (Shelke, Faubion \& Hoseney, 1990). In particular, the role of sucrose is crucial during heating as it increases the starch gelatinization and protein denaturation temperatures, allowing appropriate air cell expansion by $\mathrm{CO}_{2}$ and water vapour before the 
batter sets. PD, like sucrose, has also been found to increase the starch gelatinization temperature but not affect the protein denaturation temperature (Rosenthal, 1995).

To follow the structural changes that take place in the different reformulated muffin batters during heating in the oven, the linear viscoelastic properties were studied during a temperature sweep from $25^{\circ} \mathrm{C}$ to $95^{\circ} \mathrm{C}$.

The elastic modulus (G') and viscous modulus (G') values during heating are shown in Figure 2. In all the batters, the initial increase in temperature produced a decrease in the values of both moduli. This decrease was associated with $\mathrm{CO}_{2}$ formation in the batter, diffusion into occluded air cells and expansion, which reduced the density of the batter. The moduli values then stabilized until an increase associated with starch gelatinization and/or protein coagulation occurred.

The initial decrease in the viscoelastic moduli was much more noticeable as the level of sucrose replacement with SC-PD increased. Another difference between the control and the sucrose-reduced batter was the lower temperature at which the moduli began to increase in the sucrose replacement formulations, which reflected earlier thermosetting of the structure. This finding may be associated with the sucrose's ceasing to exert its delaying effects and the PD's having a neutral effect on the protein denaturation temperature despite delaying starch gelatinization.

The differences in heating pattern between the control and the SC-PD batters can be observed in Figure 2, where $\operatorname{tg} \delta$ values versus temperature is plotted. Throughout the temperature sweep, the increase in temperature reduced the values of $\operatorname{tg} \delta$. (values closer to 0 ), but while this decrease was gradual in the control batter, in the SC-PD batters, for sucrose replacement levels higher than $25 \%$, an evident change in the slope of the curve associated with the start of starch gelatinization or/and protein denaturation was observed.

Another feature that can be observed in Figure 2 is the decrease in the initial $\left(T=25^{\circ} \mathrm{C}\right)$ viscoelasticity of the batter ( $\operatorname{tg} \delta$ closer to 1) as the level of sucrose replacement increased. In a similar fashion to the flow property results, 
this lower viscoelasticity reveals a lower complexity of the system structure as the sucrose was replaced by SC-PD.

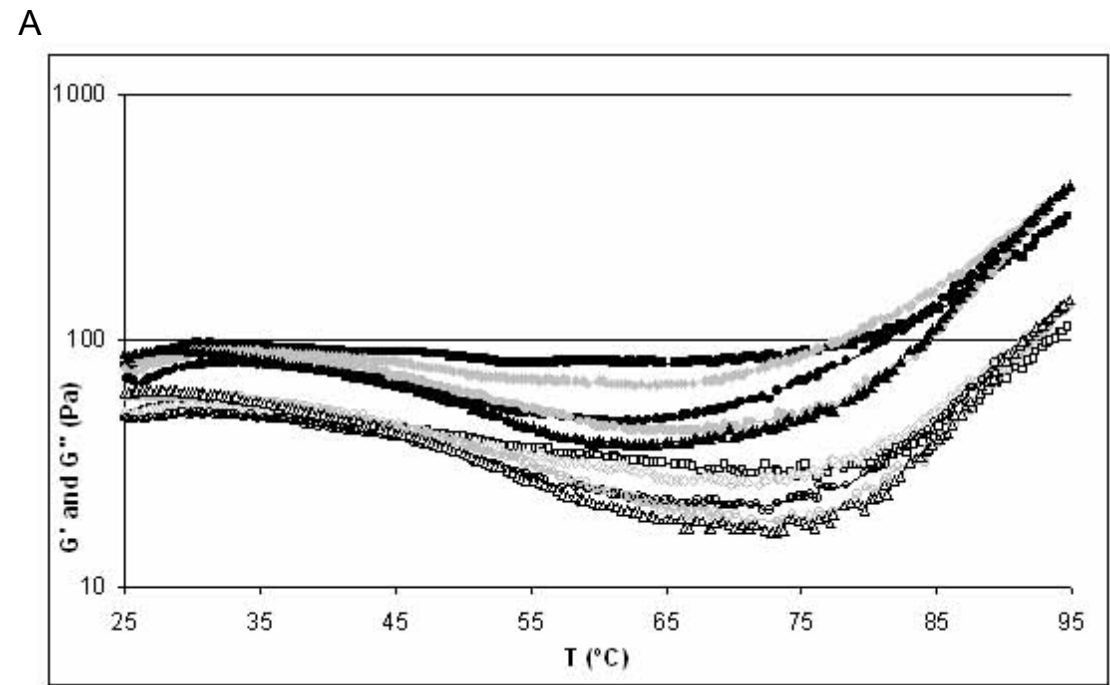

B

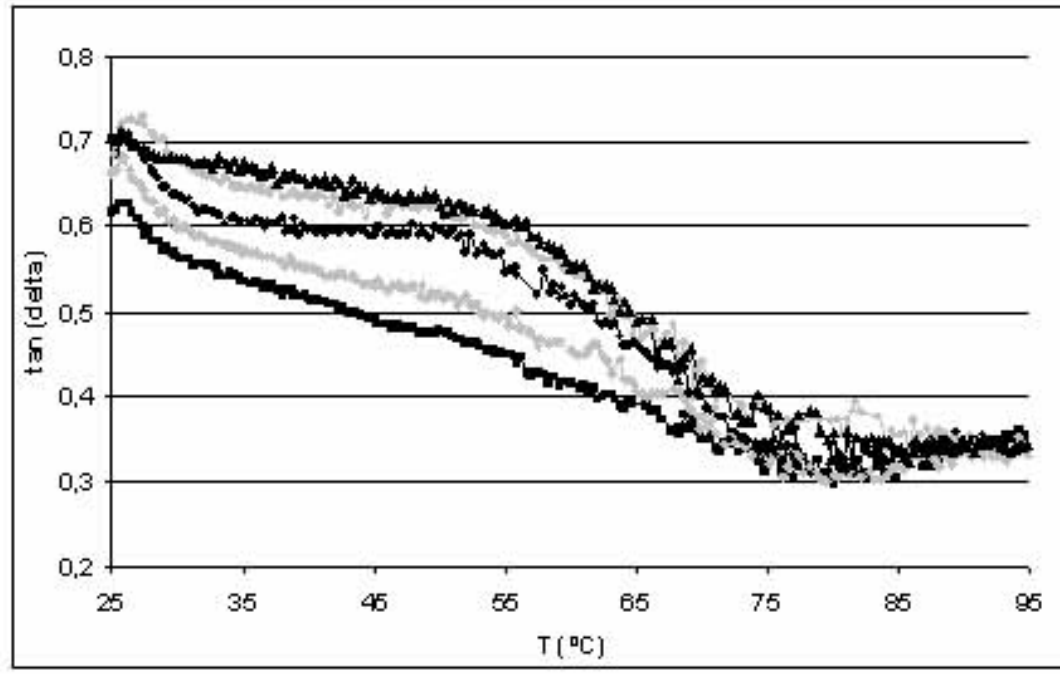

Figure 2. Elastic modulus (G') and viscous modulus (G') (A) and $\operatorname{Tg} \delta(B)$ as a function of increasing temperature in the batters prepared with increasing quantities of a polydextrose/sucralose mixture (PD-SC) as sucrose replacer. Square: Control, Diamond: 25\%PD-SC, Black circle: 50\%PD-SC, Grey circle: 75\%PD-SC and Triangle: 100\%PD-SC. In figure 2A: closed symbols: G' and opened symbols: G'. 


\subsection{Muffin air cells and muffin height}

In order to obtain an aerated structure in the final baked product, air bubbles have to be present in the batter. Two mechanisms permit air bubble entrapment: the primary mechanism involves the incorporation of such bubbles directly from the headspace due to the rotation of the mixer whisks and the secondary one involves the formation of entrapped bubbles through the breakup of larger ones (Massey, Khare \& Niranjan, 2001). Foam is formed when air is incorporated into the liquid phase upon agitation, which occurs during beating and mixing. The larger air cells incorporated into the batter matrix are then broken up further during mixing, reducing the mean bubble size and increasing the number of air cells (Mills, Wilde, Salt \& Skeggs, 2003). During baking, a second step takes place: the air cells are expanded by $\mathrm{CO}_{2}$ and the vapour pressure generated, resulting in the formation of the final gas cells, which influence the texture of the finished product.

Photographs of transversal and longitudinal sections of the different muffin formulations are shown in Figure 1. The longitudinal section reveals the presence of tunnels (or diffusion pathways), which progressively diminished upon higher sucrose replacement. The lack of diffusion pathways as the sucrose was replaced may be associated with the earlier thermosetting, not allowing enough time for bubble expansion and the formation of diffusion pathways.

The images of the transversal section also reveal that the number of air cells progressively decreased as the sucrose was replaced. This observation can be objectively shown in Table 3, which shows the total number of air cells and the number of air cells grouped by size segments. For sucrose replacement levels higher than $25 \%$, a significant decrease in the number of air cells was observed for all the cell sizes.

This result indicated that part of the tiny bubbles seen in the batters were lost later during heating or/and that not all of them could expand appropriately during heating, resulting in a more compact structure with a low number of air cells and with an absence of interconnectivity for the 100\% 
sucrose replacement level. These circumstances could be related to two factors. The first is the lower viscosity and limited structural complexity (lower viscoelasticity) of the reduced sucrose muffin batter, which may have favoured bubble buoyancy: the batter should have the necessary consistency to retain air during the baking stage. The second is the excessively early thermosetting associated with the decreased sucrose content and the lack of effect of the PD on the protein denaturation temperature. As the premature thermosetting of the protein matrix starts in the crust region, the heat transfer mechanism is gradually converted from convection to conduction starting from the surface. In turn, this lowers the heat transfer rate and consequently the vapour pressure build-up, causing inadequate expansion of individual air cells. As a result, the cell structure is characterized by relatively small air cells with less interconnectivity.

Table 3. Weight loss during baking (WLDB), height and air cell number and distribution for muffins prepared with increasing quantities of polydextrose and sucralose (PD-SC) replacing sucrose.

\begin{tabular}{|c|c|c|c|c|c|c|}
\hline \multirow[t]{2}{*}{ Samples } & \multirow{2}{*}{$\begin{array}{l}\text { WLDB } \\
\text { (g) }\end{array}$} & \multirow{2}{*}{$\begin{array}{l}\text { Height } \\
(\mathrm{mm})\end{array}$} & \multicolumn{3}{|c|}{$\begin{array}{c}\text { Air cells number } \\
\text { Area range }\left(\mathrm{m}^{2} \times 10^{-6}\right)\end{array}$} & \multirow{2}{*}{$\begin{array}{l}\text { Total } \\
\text { number }\end{array}$} \\
\hline & & & $1.00-4.9$ & $5.0-9.9$ & $10.0-50.0$ & \\
\hline Control & $\begin{array}{l}13.8 a \\
(0.5)\end{array}$ & $\begin{array}{l}\text { 46.9ab } \\
(2.2)\end{array}$ & $\begin{array}{l}33.7 a \\
(6.0)\end{array}$ & $\begin{array}{l}7.0 \mathrm{a} \\
(2.0)\end{array}$ & $\begin{array}{l}7.7 a \\
(0.6)\end{array}$ & $\begin{array}{l}48.3 a \\
(5.7)\end{array}$ \\
\hline 25\%PD-SC & $\begin{array}{l}12.5 \mathrm{~b} \\
(0.7)\end{array}$ & $\begin{array}{l}47.9 a \\
(1.9)\end{array}$ & $\begin{array}{l}46.7 a \\
(10.3)\end{array}$ & $\begin{array}{l}7.0 \mathrm{a} \\
(3.0)\end{array}$ & $\begin{array}{l}7.3 \mathrm{ab} \\
(3.0)\end{array}$ & $\begin{array}{l}61.0 \mathrm{a} \\
(8.5)\end{array}$ \\
\hline $50 \%$ PD-SC & $\begin{array}{l}12.6 \mathrm{~b} \\
(0.9) \\
\end{array}$ & $\begin{array}{l}44.9 \mathrm{c} \\
(1.3)\end{array}$ & $\begin{array}{l}10.0 \mathrm{~b} \\
(0.0)\end{array}$ & $\begin{array}{l}1.7 \mathrm{~b} \\
(0.6)\end{array}$ & $\begin{array}{l}3.7 a b c \\
(1.2)\end{array}$ & $\begin{array}{l}15.3 \mathrm{~b} \\
(0.6)\end{array}$ \\
\hline 75\%PD-SC & $\begin{array}{l}12.2 \mathrm{~b} \\
(0.6)\end{array}$ & $\begin{array}{l}44.4 \mathrm{c} \\
(1.4)\end{array}$ & $\begin{array}{l}10.7 \mathrm{~b} \\
(0.6)\end{array}$ & $\begin{array}{l}0.7 \mathrm{~b} \\
(0.6)\end{array}$ & $\begin{array}{l}2.7 \mathrm{bc} \\
(2.1)\end{array}$ & $\begin{array}{l}14.0 \mathrm{~b} \\
(2.6)\end{array}$ \\
\hline $100 \% P D-S C$ & $\begin{array}{l}12.8 \mathrm{~b} \\
(0.6)\end{array}$ & $\begin{array}{l}45.4 \mathrm{bc} \\
(1.7)\end{array}$ & $\begin{array}{l}5.0 \mathrm{~b} \\
(1.7)\end{array}$ & $\begin{array}{l}1.3 \mathrm{~b} \\
(0.6)\end{array}$ & $\begin{array}{l}0.3 c \\
(0.6)\end{array}$ & $\begin{array}{l}6.7 \mathrm{~b} \\
(1.5)\end{array}$ \\
\hline
\end{tabular}

Values in parentheses are standard deviations. Means in the same column without a common letter differ $(P<0.05)$ according to the least significant difference multiple range test.

The heights of the control and 25\%PD-SC samples were significantly greater than those of the muffins that contained more than 50\%PD-SC. The decrease in the number of diffusion pathways and air cells could be associated with a decrease in muffin height (Table 3 ) for levels of sucrose replacement 
higher than 25\%. Hicsasmaz, Yazgan, Bozoglu \& Kaunas (2003) found that the population of small cells increased, crack-like cells diminished and sphere-like cells increased with an increase in sucrose replacement by polydextrose in a cake system. This change in the shape and size of the air cells was also associated with height loss.

The values for weight loss during baking were significantly lower for the samples containing PD-SC (Table 3). The average weight loss during baking was $13 \%$ for samples with PD-SC, while the control sample lost about $14 \%$.

\subsection{Muffin colour}

An increase in PD-SC substitution produced a decrease in the lightness of the crumb and an increase in the redness and yellowness values (Table 4), that is to say, the crumb acquired a more saturated yellowish colour. It should be noted that, as expected, all the muffin crusts were darker than the muffin crumbs due to the effect of baking, during which Maillard reactions occurred.

Table 4. Mean colour for muffins prepared with increasing quantities of polydextrose and sucralose (PD-SC) replacing sucrose.

\begin{tabular}{lllllllll}
\hline \multirow{2}{*}{ Sample } & \multicolumn{4}{c}{ Crust colour } & \multicolumn{5}{c}{ Crumb colour } \\
\cline { 2 - 8 } & \multicolumn{1}{c}{$\mathrm{L}^{*}$} & \multicolumn{1}{c}{$\mathrm{a}^{*}$} & \multicolumn{1}{c}{$\mathrm{b}^{*}$} & $\Delta \mathrm{E}^{*}$ & \multicolumn{1}{c}{$\mathrm{L}^{*}$} & \multicolumn{1}{c}{$\mathrm{a}^{*}$} & \multicolumn{1}{c}{$\mathrm{b}^{*}$} & $\Delta \mathrm{E}^{*}$ \\
\hline \multirow{2}{*}{ Control } & $\begin{array}{l}51.4 \mathrm{a} \\
(6.7)\end{array}$ & $\begin{array}{l}13.1 \mathrm{a} \\
(4.7)\end{array}$ & $\begin{array}{l}34.9 \mathrm{a} \\
(3.9)\end{array}$ & 0.0 & $\begin{array}{l}66.6 \mathrm{a} \\
(2.6)\end{array}$ & $\begin{array}{l}1.3 \mathrm{a} \\
(0.2)\end{array}$ & $\begin{array}{l}18.5 \mathrm{a} \\
(1.3)\end{array}$ & \multirow{2}{*}{0.0} \\
\hline \multirow{2}{*}{$25 \%$ PD-SC } & $\begin{array}{l}46.4 \mathrm{a} \\
(3.9)\end{array}$ & $\begin{array}{l}16.0 \mathrm{a} \\
(3.1)\end{array}$ & $\begin{array}{l}35.6 \mathrm{ab} \\
(3.1)\end{array}$ & 5.9 & $\begin{array}{l}65.6 \mathrm{ab} \\
(2.4)\end{array}$ & $\begin{array}{l}1.6 \mathrm{ab} \\
(0.3)\end{array}$ & $\begin{array}{l}20.7 \mathrm{ab} \\
(1.1)\end{array}$ & \multirow{2}{*}{2.3} \\
\hline \multirow{2}{*}{$50 \%$ PD-SC } & $\begin{array}{l}49.3 \mathrm{a} \\
(7.11)\end{array}$ & $\begin{array}{l}10.5 \mathrm{a} \\
(6.1)\end{array}$ & $\begin{array}{l}35.4 \mathrm{a} \\
(5.6)\end{array}$ & \multirow{2}{*}{3.3} & $\begin{array}{l}62.4 \mathrm{bc} \\
(2.2)\end{array}$ & $\begin{array}{l}1.9 \mathrm{ab} \\
(0.5)\end{array}$ & $\begin{array}{l}20.9 \mathrm{~b} \\
(1.8)\end{array}$ & \multirow{2}{*}{4.8} \\
\hline \multirow{2}{*}{$75 \%$ PD-SC } & $\begin{array}{l}44.5 \mathrm{a} \\
(5.9)\end{array}$ & $\begin{array}{l}14.7 \mathrm{a} \\
(4.7)\end{array}$ & $\begin{array}{l}42.1 \mathrm{~b} \\
(4.5)\end{array}$ & \multirow{2}{*}{10.1} & $\begin{array}{l}60.6 \mathrm{~cd} \\
(3.8)\end{array}$ & $\begin{array}{l}2.1 \mathrm{~b} \\
(0.5)\end{array}$ & $\begin{array}{l}20.7 \mathrm{ab} \\
(2.0)\end{array}$ & \multirow{2}{*}{6.4} \\
\hline \multirow{2}{*}{$100 \%$ PD-SC } & $\begin{array}{l}44.8 \mathrm{a} \\
(6.9)\end{array}$ & $\begin{array}{l}15.4 \mathrm{a} \\
(4.9)\end{array}$ & $\begin{array}{l}38.3 \mathrm{ab} \\
(5.3)\end{array}$ & \multirow{2}{*}{8.1} & $\begin{array}{l}58.4 \mathrm{~d} \\
(2.2)\end{array}$ & $\begin{array}{l}3.4 \mathrm{c} \\
(0.7)\end{array}$ & $\begin{array}{l}24.5 \mathrm{c} \\
(1.1)\end{array}$ & \multirow{2}{*}{10.4} \\
\hline
\end{tabular}

Values in parentheses are standard deviations. Means in the same column without a common letter differ $(P<0.05)$ according to the least significant difference multiple range test.

No significant differences were observed in the $L^{*}$ and $a^{*}$ values of the muffin crusts, but the $b^{*}$ values were significantly higher in the formulations with a high degree of substitution of PD-SC for sucrose (Table 4). From the above 
results, it is concluded that the reduced-sugar muffins had a more orangey colour than the control.

The $\Delta \mathrm{E}^{*}$ values were in excess of 3 units for almost all the samples when compared with the control, therefore these differences would be appreciated by the human eye (Table 4). However, it is worth noting that no strange colours appeared.

\subsection{Instrumental texture of muffins}

The replacement of sucrose by a PD-SC mixture gave the muffins a softer texture compared with the control (Table 5). The hardness values of all the samples with a sucrose replacement higher than $25 \%$ were lower than those obtained for the control and 25\%PD-SC samples. No significant differences in hardness were found at sucrose replacement levels higher than $50 \%$. The same applies to springiness, cohesiveness, chewiness and resilience. The springiness value of the lowest sucrose replacement sample (25\%) was not significantly different from that of the control; however, the springiness, cohesiveness and resilience values fell significantly as the sucrose was increasingly replaced by PD-SC, reflecting a more compact crumb (Table 5 ). This result could be related to the retarding effect of sugar on the starch gelatinization temperature, which has been found to result in a tenderizing effect on muffin texture (Barndt \& Antenucci, 1993). Similar results were found by Akesowan (2009) in chiffon cake when sucrose was replaced by a sucraloseerythritol mixture. Ronda, Gómez, Blanco \& Caballero (2005) also found a decrease in the firmness of sugar-free sponge cakes prepared with polydextrose. The instrumental texture results for the muffins agreed with the results for muffin air cell number and size. Generally, denser masses with lower numbers of gas cells obtain lower resilience values, implying that it will take more time for the structure of the muffin to recover after compression.

Chewiness is a secondary texture parameter that is associated with difficulty in chewing the sample and forming a bolus before swallowing. The chewiness values followed the same trend as the hardness values (Table 5). 
These values fell significantly as PD-SC was increasingly substituted for sucrose, indicating that compared with the controls, low sucrose muffins were easy to chew.

Table 5. TPA values $(\mathrm{H}$ : hardness, S: springiness, C: cohesiveness, Ch: chewiness, R: resilence) for muffins prepared with increasing quantities of polydextrose and sucralose (PD-SC) replacing sucrose.

\begin{tabular}{llllll}
\hline \multirow{2}{*}{ Samples } & \multicolumn{5}{c}{ TPA parameters } \\
\cline { 2 - 6 } & $\mathrm{H}(\mathrm{N})$ & \multicolumn{1}{c}{$\mathrm{S}$} & $\mathrm{C}$ & $\mathrm{Ch}(\mathrm{N})$ & $\mathrm{R}$ \\
\hline \multirow{2}{*}{ Control } & $3.76 \mathrm{a}$ & $0.85 \mathrm{a}$ & $0.64 \mathrm{a}$ & $2.05 \mathrm{a}$ & $0.26 \mathrm{a}$ \\
& $(0.49)$ & $(0.04)$ & $(0.01)$ & $(0.27)$ & $(0.01)$ \\
\hline \multirow{2}{*}{$25 \%$ PD-SC } & $3.45 \mathrm{a}$ & $0.83 \mathrm{ab}$ & $0.60 \mathrm{~b}$ & $1.74 \mathrm{~b}$ & $0.23 \mathrm{~b}$ \\
& $(0.63)$ & $(0.05)$ & $(0.03)$ & $(0.33)$ & $(0.02)$ \\
\hline \multirow{2}{*}{$50 \%$ PD-SC } & $2.72 \mathrm{~b}$ & $0.80 \mathrm{~b}$ & $0.59 \mathrm{bc}$ & $1.29 \mathrm{c}$ & $0.21 \mathrm{c}$ \\
& $(0.53)$ & $(0.07)$ & $(0.03)$ & $(0.27)$ & $(0.02)$ \\
\hline \multirow{2}{*}{$75 \%$ PD-SC } & $3.39 \mathrm{~b}$ & $0.79 \mathrm{~b}$ & $0.56 \mathrm{c}$ & $1.08 \mathrm{c}$ & $0.19 \mathrm{~d}$ \\
& $(0.43)$ & $(0.02)$ & $(0.03)$ & $(0.20)$ & $(0.01)$ \\
\hline \multirow{2}{*}{$100 \% \mathrm{PD}-\mathrm{SC}$} & $2.27 \mathrm{~b}$ & $0.70 \mathrm{c}$ & $0.47 \mathrm{~d}$ & $0.73 \mathrm{~d}$ & $0.15 \mathrm{e}$ \\
& $(0.43)$ & $(0.04)$ & $(0.07)$ & $(0.14)$ & $(0.02)$ \\
\hline
\end{tabular}

Values in parentheses are standard deviations. Means in the same column without a common letter differ $(P<0.05)$ according to the least significant difference multiple range test.

\subsection{Muffin acceptability}

The average results of the sensory evaluation of low-sugar muffins are shown in Figure 3. The sample with $50 \%$ of the sugar replaced by the PD-SC mixture had similar appearance, colour, texture, flavour, sweetness and overall acceptability scores to those of the control (Figure 3).

The muffins with $100 \%$ sucrose replacement obtained lower acceptability scores in all the attributes. The lowest acceptability score was found for texture; taking into account the instrumental texture parameters obtained it seemed that consumers did not like the low springiness conferred by $100 \%$ sucrose replacement, which did not provide an acceptable texture; these muffins would probably be considered too compact and under-aerated, while the low hardness and cohesiveness would probably be of minor importance. Similar results in other systems have been obtained by several authors. Ronda, Gómez, Blanco \& Caballero (2005) also found significantly lower overall 
acceptability scores in sugar-free sponge cakes prepared with PD. However, they concluded that the poor sensory scores for the PD cakes were mainly related to their lack of sweetness. On the other hand, the use of SC for sucrose replacement at concentrations higher than $60 \%$ in chiffon cake produced low overall liking, associated with less tenderness and crust colour, as described by a trained panel (Lin \& Lee, 2005).

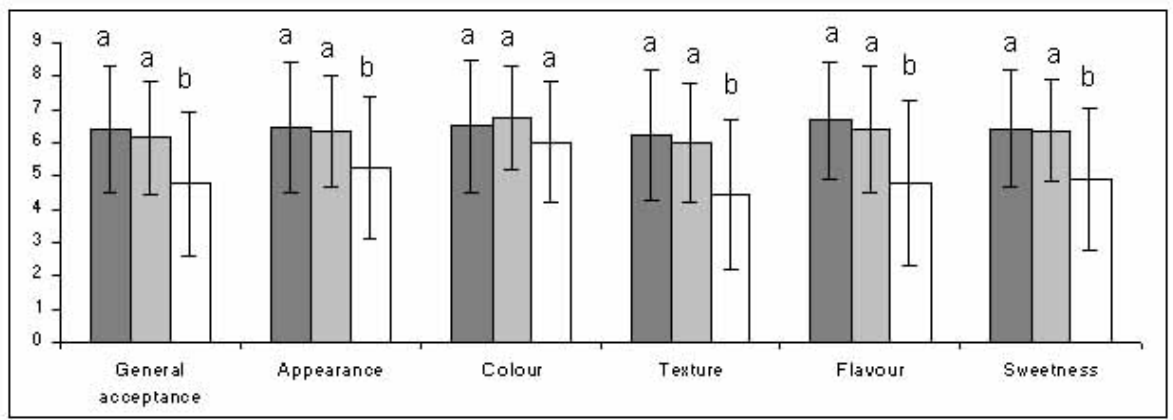

Figure 3. Sensory acceptability to consumers of muffins prepared with increasing quantities of a polydextrose/sucralose mixture (PD-SC) as sucrose replacer. Dark grey bars: Control, Grey bars: 50\%PD-SC and White bars: $100 \%$ PD-SC.

\section{Conclusions}

The sucralose/polydextrose mixture has been shown to be a suitable sucrose replacement for low-sucrose reformulated muffins. Replacement of $25 \%$ sucrose by a mixture of PD-SC altered none of the eating quality properties of the reformulated muffins. Further replacement of sucrose by PDSC progressively affected the batter structure, both before and during the baking process. As the sucrose was replaced the viscosity and viscoelasticity of the raw batter decreased, as did the structure setting temperature. These circumstances do not favour appropriate bubble expansion, even though the PD-SC batters had an appropriate initial number and distribution of air bubbles. The result was a muffin with less height and fewer final air cells as the sucrose was replaced, and with low hardness and springiness. The sensory 
acceptability results indicated that sucrose can be replaced up to a level of $50 \%$ with good sensory acceptability, but $100 \%$ sucrose replacement brings a significant decrease in acceptability, the lowest scores being associated with texture failure.

\section{References}

Attia A, El-Said, Shehata HA \& Askar A (1993) An alternative formula for the sweetening of reduced calorie cakes. Food Chemistry 48 (2), 169-172.

Baeva MR, Terzieva VV \& Panchev IN (2003) Structural development of sucrose-sweetened and sucrose-free sponge cakes during baking. Nahrung/Food 47 (3), 154-160.

Barndt RL \& Jackson G (1990) Stability of sucralose in baked goods. Food Technology 44 (1), 62-66.

Barndt RL \& Antenucci RN (1993) Fat and calorie modified bakery products. En: Low-calorie foods and food ingredients (pp: 106-137). Editado por: R. Khan. Blackie Academic and Professional (London, UK).

Beesley PM (1995) Sugar functionality reviewed. Food Technology International Europe, 87-89.

Frye AM \& Setser CS (1991) Optimising texture of reduced-calorie yellow layer cakes. Cereal Chemistry 69 (3), 338-343.

Hanselmann W \& Windhab E (1999) Flow characteristics and modelling of foam generation in a continuous rotor/stator mixer. Journal of Food Engineering 38, 393-405.

Hicsasmaz Z, Yazgan Y, Bozoglu F \& Kaunas Z (2003) Effect of polydextrosesubstitution on the cell structure of the higt-ratio cake system. Lebensmittel-Wissenschaft und Technologie 36 (4), 441-450.

Knight I (1994) The developenemt and applications of sucralose, a new highintensity sweetener. Canadian Journal of Physiology and Pharmacology 72, 435-439. 
Kocer D, Hicsasmaz Z, Bayindirli A \& Katnas S (2007) Bubble and pore formation of the high-ratio cake formulation with polydextrose as a sucrose and fat replacer. Journal of Food Engineering 78 (3), 953-964.

Lin SD \& Lee CC (2005) Qualities of chiffon cake prepared with indigestible dextrin and sucralose as replacement for sucrose. Cereal Chemistry 82 (4), 405-413.

Massey AH, Khare AS \& Niranjan K (2001) Air inclusion into a model cake batter using a pressure whisk: development of gas hold-up and bubble size distribution. Journal of Food Science 66 (8), 1152-1157.

Mills ENC, Wilde PJ, Salt LJ \& Skeggs P (2003) Bubble formation and stabilization in bread dough. Food and Bioproducts Processing 81 (C3), 189-193.

Roberfroid M \& Slavin J (2000) Nondigestible oligosaccharides. Critical Reviews in Food Science and Nutrition 40 (6), 461-480.

Ronda F, Gómez M, Blanco CA \& Caballero PA (2005) Effects of polyols and nondigestible oligosaccharides on the quality of sucrose-free sponge cakes. Food Chemistry 90 (4), 549-555.

Rosenthal AJ (1995) Application of aged egg in enabling increased substitution of sucrose by litesse (polydextrose) in high-ratio cakes. Journal of the Science of Food and Agriculture 68, 127-131.

Shelke K, Faubion JM \& Hoseney R (1990) The dynamics of cake baking as studied by a combination of viscosimetry and electrical resistance oven heating. Cereal Chemistry 67(6), 575-580.

Torres A \& Thomas RD (1981) Polydextrose and its applications in food. Food Technology 35 (7), 44-49. 


\section{CAPÍTULO 2}

EFFECT OF USING ERYTHRITOL AS A SUCROSE REPLACER IN MAKING SPANISH MUFFINS INCORPORATING XANTHAN GUM

Martínez-Cervera S, de la Hera E, Sanz T, Gómez M \& Salvador $A$

FOOD AND BIOPROCESS TECHNOLOGY (2012), 5, 3203-3216. 



\section{Abstract}

Spanish muffins are sweet, high-calorie baked products which are highly appreciated for their good taste and soft texture. The aim of this work was to evaluate the suitability of erythritol and of its combination with xanthan gum and double quantities of leavening agent for replacing sucrose in Spanish muffins, and to understand their functionality in a muffin system.

The linear viscoelastic properties of the batter during heating, its specific gravity and bubbles, muffin weight loss during baking and muffin bubbles, height, volume and instrumental texture were studied.

Both erythritol and sucrose increase in the temperature at which the viscoelastic functions increased with temperature. In comparison with the reduced sucrose muffins, the use of erythritol increased the number of air bubbles in the batter. The height of the muffins also increased in the presence of erythritol when compared to the corresponding reduced sucrose muffins, although the volume did not.

Erythritol was not effective in diminishing the increased hardness associated with sucrose reduction, but the combination of erythritol with xanthan gum and a double quantity of leavening agent significantly improved the muffin volume (from $94 \mathrm{~cm}^{3}$ for $100 \%$ erythritol formulation to $108 \mathrm{~cm}^{3}$ for $100 \%$ erythritol-xanthan-double leaving agent formulation) and significantly decreased the hardness (from $75 \mathrm{~N}$ for $100 \%$ erythritol formulation to $25 \mathrm{~N}$ for $100 \%$ erythritol-xanthan-double leaving agent formulation).

Keywords: sucrose, erythritol, muffins, sweeteners, texture, xanthan gum. 


\section{Introduction}

Spanish muffins are sweet, high-calorie baked products which are highly appreciated by consumers due to their good taste and soft texture. The principal problem is that their high fat and sucrose content makes them a high calorie product. Sucrose has a high glycemic index and for this reason diabetic people should not consume large quantities of bakery products.

Spanish muffin batter is a complex fat-in-water emulsion. The final product is characterized by a typical porous structure and high specific volume, which confers a spongy texture. To obtain such a final structure, a stable batter lodging many tiny air bubbles is required and these bubbles must be distributed evenly. Shortening and oil are used to give a softer structure and to avoid a dry mouth feel. Sucrose contributes to the sweet taste, provides a considerable part of the bulk in batters, helps baked goods stay moist, and limits the swelling of starch, which helps to create a finer texture (Beesley, 1995). Under non-acidic conditions, it contributes not only the browning of the crust but also of the crumb. One important role of sucrose is to raise starch gelatinization and protein denaturation temperatures during cake baking. Furthermore, sucrose promotes fat-crystal aggregates, thus enhancing air entrapment and the stabilization of air bubbles during baking (Beesley, 1995).

Due to the complex structural functionality of sucrose in baked products, obtaining good quality low-sucrose products is a difficult task. Sugar alcohols are typical sucrose replacers in baked goods (Olinger \& Velasco, 1996) and their properties have been studied by many authors (Kamel \& Rasper, 1988; Baeva et al.,2003; ), Ronda et al.,2005). Erythritol (Er) plays a similar role to sucrose, providing some of its properties in bakery products (Haji, 2009). Erythritol is a 4-carbon sugar alcohol with about $60 \%$ to $80 \%$ of the sweetness of sucrose (Goossens \& Roeper, 1994) which is obtained via a natural fermentation process (Haji, 2009). It is suitable for people with diabetes because blood glucose and insulin levels do not increase when erythritol is administered orally to healthy male subjects (Noda et al., 1994). Erythritol can 
replace sucrose, reducing the calorie content of the product to less than 0.5 $\mathrm{kcal} / \mathrm{g}$ (Oku \& Noda, 1990). Tetzloff et al. (1996) studied the effect of addition of erythritol at a concentration of $1 \mathrm{~g} / \mathrm{kg}$ body weight in the diet of 12 healthy male volunteers and they found no problems of intolerance at this dose. Therefore, the conclusion of this study was that $1 \mathrm{~g} / \mathrm{kg}$ body weight was well tolerated by humans. Lin and coworkers (2003) studied the sensory quality and physical characteristics of chiffon cake with replacement of sucrose by erythritol, obtaining comparable results to cake prepared with $100 \%$ sucrose. Akesowan (2009) studied the replacement of sucrose by a mixture of erythritol and sucralose in reduced fat chiffon cakes and obtained acceptable sensory quality in a $50 \%$ erythritol-sucrose chiffon cake, although a $50 \%$ erythritol-sucrose system is not suitable for diabetic products.

A strategy to improve the physicochemical properties of baked products is to add hydrocolloids to the batters. Hydrocolloids change the viscosity of batters and aid air incorporation during batter mixing, thus achieving an improvement in the height and volume of the final product. (Ronda et al., 2009; Khouryieh et al.,2005; Turabi et al., 2008). Xanthan gum is a microbial polysaccharide produced by fermentation of Xanthamonas campestris. Miller \& Hoseney (1993) studied the role of xanthan gum in white layer cakes and concluded that xanthan gum increased the height of the cakes, increased the batter viscosity and prevented gas loss during baking at $79-91^{\circ} \mathrm{C}$. Ashwini et al. (2009) studied the effect of different hydrocolloids on eggless cake and showed that when xanthan gum was added to the batters, the viscosity increased and the wheat starch granules appeared to be wrapped in the xanthan gum, as they were not visible. In yellow layer cakes, xanthan gum has been associated with an increase in volume, despite a reduction in air retention (Gómez et al., 2007). The combination of xanthan gum with a larger amount of leavening could be a possibility for counterbalancing the negative effect of xanthan gum on air retention capacity.

The aim of this work was to evaluate the suitability of erythritol to replace sucrose in Spanish muffins and to understand its functionality in the 
properties of both the batter and the baked muffin. A combination of erythritol with xanthan gum and double quantities of leavening agent was also studied.

\section{Materials and Methods}

\subsection{Batter and muffin preparation}

Fourteen muffin formulations (Table 1) were prepared by replacing part or all of the sucrose with erythritol (Er) or erythritol and xanthan gum (ErXan), or reducing or eliminating it without adding a replacement (SR). The Spanish muffin ingredients were wheat flour (10.9\% moisture; $8.98 \%$ protein) supplied by Harinera Castellana S.A. (Medina del Campo, Spain) pasteurized whole egg (Ovopack, Marchena, Spain), refined sunflower oil (Koipesol, Madrid, Spain), whole UHT milk (Carrefour, Madrid Spain), sucrose (Acor, Valladolid, Sapin), erythritol (Zerose TM 16957, Cargill, Martorell, Spain), xanthan gum (Santiaxane CX-91, Cargill, Martorell, Spain), tap water, sodium bicarbonate (Martínez, Cheste, Spain), citric acid (Martínez, Cheste, Spain) and salt (sodium chloride). The samples were identified as control, controlXan, 25\%SR, 50\%SR, 75\%SR, 100\%SR, 25\%Er, 50\%Er, 75\%Er, 100\%Er, 25\%ErXan, 50\%ErXan, 75\%ErXan and 100\%ErXan (Table 1).

The batter was prepared in a KPM5 professional mixer (Kitchen Aid, St. Joseph, Michigan, USA), in which the egg was whisked for 2 minutes at top speed (speed 10) and the sucrose, erythritol and xanthan gum (depending on the formulation) were added and mixed in for 30 seconds. Then, the mixer speed was reduced to 4 and water, citric acid and half the milk were added and mixed for 1 minute. The flour, sodium bicarbonate and sodium chloride were added and the mixture was beaten for a further 1 minute. Lastly, the mixer speed was increased to 6 , the rest of the milk and water were added and the oil was gradually dripped in. The mixture was beaten for 3 minutes until it was smooth. 


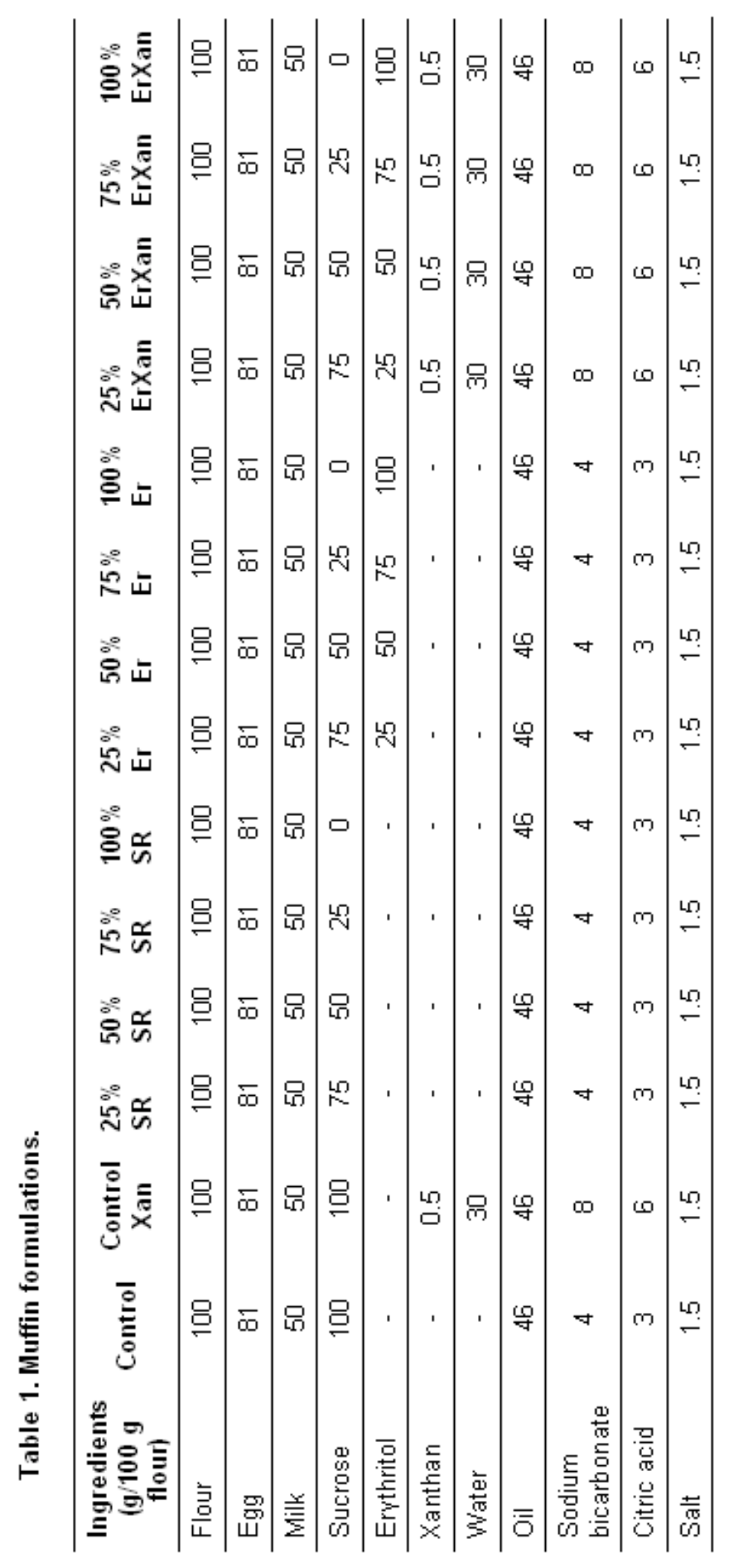




\subsection{Muffin preparation}

With the aid of a balance, $45 \mathrm{~g}$ of batter was dosed exactly into each 60 $\mathrm{mm}$ diameter $\mathrm{x} 36 \mathrm{~mm}$ high paper mold. 12 molds were arranged in three rows of four muffins on a baking tray and baked for 25 minutes at $190^{\circ} \mathrm{C}$ in an ST-02 modular electric oven (Salva, San Sebastián, Spain) that had been preheated to this temperature for 1 hour.

The muffins were left to cool at room temperature for one hour. The twelve muffins baked on the same baking tray were packed in a polyethylene bag, hermetically sealed and stored at $20{ }^{\circ} \mathrm{C}$ for one day until the determinations were conducted.

All the formulations were prepared at least in duplicate.

\subsection{Properties of the batter}

\subsubsection{Specific gravity}

The specific gravity of the batter (SG) was measured as the ratio of the weight of a standard container filled with batter (W2) to that of the same container filled with water (W1) (Eq. 1) (specific gravity $=1 \mathrm{~g} / \mathrm{ml}$ ) (Kissell \& Bean, 1978):

$$
S G=W 2 / W 1
$$

Each formulation was measured twice.

\subsubsection{Bubbles in the batter}

The batter samples were imaged using a DM750 microscope (Leica Microsystems, Wetzlar, Alemania) with a magnification of 40x. A linked EC3 video camera (Leica Microsystems, Wetzlar, Alemania) provided images using LAS EZ software (Leica Microsystems, Wetzlar, Alemania). Image processing was performed using Image Pro-Plus 4.5 software (Media Cybernetics, Bethesda MD, USA). The images were converted to an 8-bit grey scale and segmented separately using a histogram-based segmentation.

Eight replicates of each formula were photographed. 


\subsubsection{Rheology}

The linear viscoelastic properties of the muffin batters were studied using an AR G2 controlled-stress rheometer (TA Instruments, Crawley, UK). The batters were all kept at $25^{\circ} \mathrm{C}$ for $60 \mathrm{~min}$ after batter preparation before the rheological test. The samples were allowed to rest in the measurement cell for a 25 min equilibration time. A $40 \mathrm{~mm}$ diameter plate-plate sensor geometry with a serrated surface and a $1 \mathrm{~mm}$ gap was employed. To simulate the effect of heating in the batter structure, temperature sweeps were performed from $25^{\circ} \mathrm{C}$ to $95^{\circ} \mathrm{C}$ at a heating rate of $1.0^{\circ} \mathrm{C} / \mathrm{min}$ and a strain amplitude of 0.0005 . The strain applied was selected to guarantee the existence of a linear viscoelastic response according to previous stress sweeps carried out at $25^{\circ} \mathrm{C}$ and $95^{\circ} \mathrm{C}$. Vaseline oil was applied to the exposed surfaces of the samples to prevent sample drying during testing.

Each formulation was measured twice.

\subsection{Properties of the muffins}

\subsubsection{Weight loss}

The muffins were numbered by marking the underside of the mold and were weighed before (W3) and after baking and cooling (W4) (Eq. 2). The weight loss upon baking was calculated as follows:

$$
\text { Weight loss }=(\text { W3-W4 })^{*} 100 / \mathrm{W} 3
$$

Fourteen replicates were carried out for each formula.

\subsubsection{Height}

Muffin height was measured with a calliper from the highest point of the muffin to the bottom of the paper mold after cooling for $1 \mathrm{~h}$ at room temperature.

Each formulation was prepared twice, on different days, and 7 muffins from each batch (fourteen determinations) were measured. 


\subsubsection{Volume}

Cake volume was determined using a laser sensor with the BVM-L 370 volume analyzer (TexVol Instruments, Viken, Sweden). This procedure involves an instrument that spins the sample round and has a sensor laser and software to calculate the volume of the whole muffins. All the measurements were carried out the day after baking and 7 samples at least were measured from each batch of each recipe (totalling 14 determinations for each of the 14 formulations).

\subsubsection{Color}

A Minolta Spectrophotometer CN-508i (Minolta, Co. LTD, Japan) was used to measure the colour of the muffins. The results were expressed in accordance with the CIELAB system (D65 illuminant and $10^{\circ}$ viewing angle). The parameters measured were $L^{*}\left(L^{*}=0\right.$ [black], $L^{*}=100$ [white] $), a^{*}\left(+a^{*}=\right.$ red) and $b^{*}\left(+b^{*}=y e l l o w\right)$. The color of the crust was measured at several points. The muffin was then cut in half on a plane parallel to its base and the color of the crumb was measured at several points on the cut surface.

The total color difference $\left(\Delta \mathrm{E}^{*}\right)$ between the control sample and each of the muffins was calculated (Eq. 3) (Francis \& Clydesdale, 1975):

$$
\Delta \mathrm{E}^{*}=\left(\left(\Delta \mathrm{L}^{*}\right)^{2}+\left(\Delta \mathrm{a}^{*}\right)^{2}+\left(\Delta \mathrm{b}^{*}\right)^{2}\right)^{1 / 2}
$$

The values used to determine if the total color difference was visually obvious were the following (Bodart et al., 2008):

- $\Delta \mathrm{E}^{*}<1$ color differences are not obvious for the human eye.

- $1<\Delta \mathrm{E}^{*}<3$ minor color differences could be appreciated by the human eye depending on the hue.

- $\Delta \mathrm{E}^{*}>3$ color differences are obvious for the human eye.

Each formulation was prepared twice, on different days, and 4 muffins from each batch (eight determinations) were measured.

\subsubsection{Instrumental texture of the muffins}

The instrumental texture measurements of the muffins were made with a TA.XT2 Texture Analyzer (Stable Microsystems, Surrey, UK) provided with 
Texture Expert software. Each formulation was prepared twice, on different days, and 4 muffins from each batch were measured (eight determinations for each formulation).

The muffins were cut horizontally at the height of the mold, the upper half was discarded and the $2.5 \mathrm{~cm}$ high lower halves were removed from the mold. A double compression test (Texture Profile Analysis (TPA)) was performed with a $75 \mathrm{~mm}$ diameter flat-ended cylindrical probe $(\mathrm{P} / 75)$ and compression to $50 \%$ of the initial height, at a speed of $1 \mathrm{~mm} / \mathrm{s}$ with a $5 \mathrm{~s}$ waiting time between the two cycles. The parameters obtained from the curves were hardness (the peak force during the first compression cycle), springiness (the height that the food recovered between the end of the first compression and the start of the second compression), cohesiveness (the ratio of the positive force area during the second compression to the positive force area during the first compression) and chewiness (the product of hardness * cohesiveness * springiness), as well as resilience (area during the withdrawal of the first compression divided by the area of the first compression).

\subsubsection{Bubbles in the muffins}

The muffins were cut on a horizontal plane at a distance of $2.5 \mathrm{~cm}$ from the base and images of the freshly cut surface of the crumb were captured using a DSC-W300 super steady shot camera (Sony, UK). Image processing was performed using Image Pro-Plus 4.5 software (Media Cybernetics, Bethesda MD, USA). The images were converted to an 8-bit grey scale and segmented separately using a histogram-based segmentation.

Each formulation was prepared twice, on different days, and 2 muffins from each batch (four determinations) were measured.

\subsection{Statistical analysis of the results}

One way-ANOVA was applied to study the effect of sugar replacement on each of the instrumental parameters. Least significant differences were calculated using the Tukey test at a significance of $P<0.05$. These analyses 
were performed using SPSS for Windows Version 12 (SPSS Inc., Chicago, USA).

\section{Results and Discussion}

\subsection{Viscoelastic behaviour during heating}

\subsubsection{Sucrose reduction and sucrose replacement with erythritol}

The structural changes that occur in the muffin batter during baking are determining factors in bubble formation and stability and determine the final baked product structure and texture (Shelke et al., 1990). In particular, the role of sucrose is crucial during heating as it increases the starch gelatinization and protein denaturation temperatures, allowing the $\mathrm{CO}_{2}$ and water vapor, and consequently the air cells, to expand sufficiently before the batter sets. To investigate the structural changes taking place in the different muffin batters during heating, the linear viscoelastic properties were studied from $25^{\circ} \mathrm{C}$ to 95 ${ }^{\circ} \mathrm{C}$, trying to simulate the batter's behavior in the oven.

The effect of eliminating sucrose (at 50 and 100\% reduction levels) and the effect of erythritol as a sucrose replacer can be seen in Figure 1A and 1B, which shows the elastic modulus, G', and tanס values (G'/G') during heating of the different batters. The initial G' and tan $\delta$ values (values at $25^{\circ} \mathrm{C}$ ) varied among the different batters. Elimination of sucrose from the control batter progressively increased the G' values and increase viscoelasticity (values of tan $\delta$ became closer to 0 ), meaning that the presence of sucrose decreased G' and the viscoelasticity of the batter system. In the same way as sucrose, although to a lesser extent, erythritol decreased the G' values and increased the viscoelasticity. At $25^{\circ} \mathrm{C}$ the viscoelastic values of the erythritol containing batter lay between those of the sucrose batter and the sample in which it was absent: at $25{ }^{\circ} \mathrm{C}$, tan $\delta$ was 0.51 for the control sample, 0.29 for $100 \%$ SR and 0.39 for $100 \%$ Er.

In all the batters, the initial increase in temperature produced a decrease in the values of the elastic moduli (G'). Initially this decrease may only 
be associated with the effect of increasing temperature, but up to a certain temperature (approximately $45^{\circ} \mathrm{C}$ ) it may be also associated with $\mathrm{CO}_{2}$ forming in the batter, diffusing into occluded air cells and expanding, resulting in a reduction in batter density (Ngo \& Taranto, 1986). This decrease was more evident for $100 \% \mathrm{SR}, 50 \% \mathrm{SR}$ and $100 \% \mathrm{Er}$ than for the control and $50 \% \mathrm{Er}$ batters. Especially in the $100 \%$ SR batter, the G' values decreased considerably until the inflexion point in the curve associated with starch gelatinization and protein coagulation was reached.

A

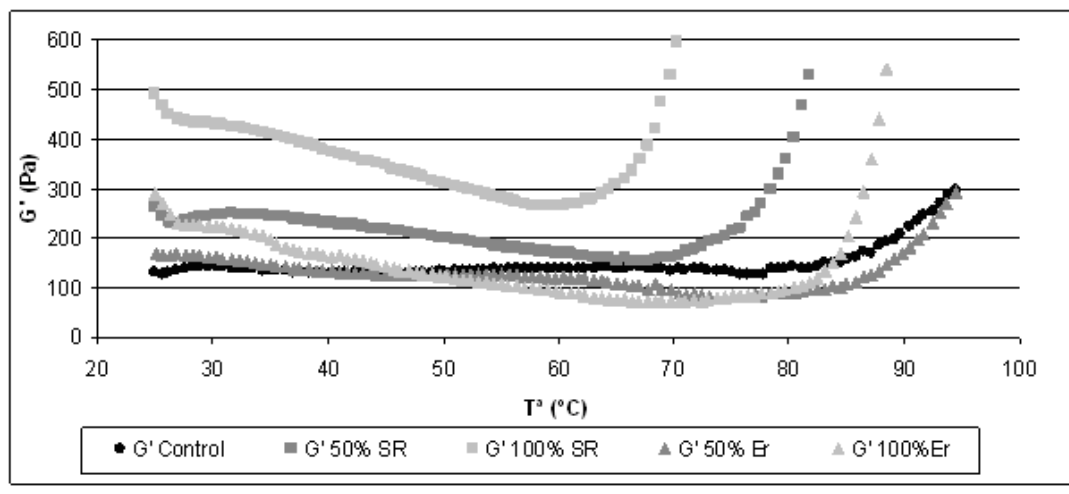

B

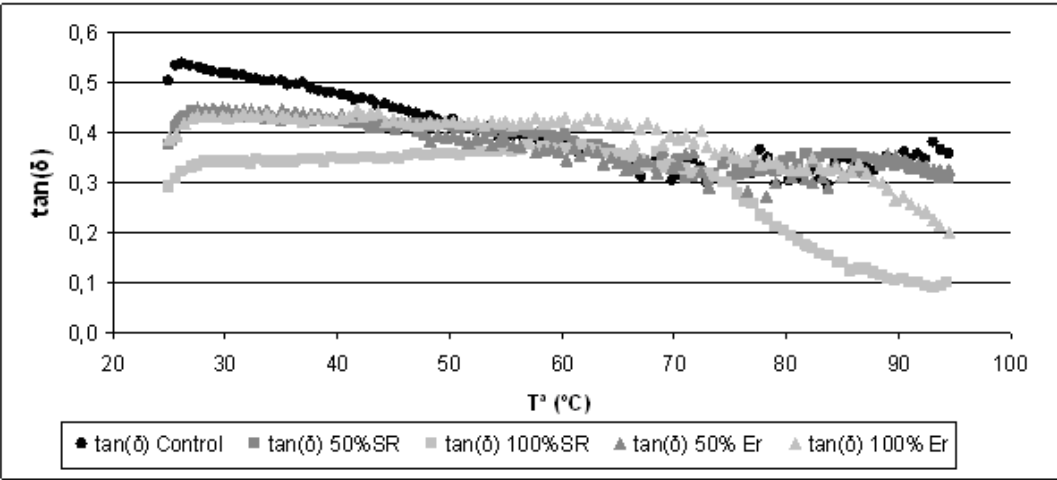

Figure 1. Elastic modulus (G') (A) and $\tan (\delta)(B)$ as a function of increasing temperature in the Spanish muffin control batter, reduced sucrose batters and batters with sucrose replaced by erythritol. 
As expected, sucrose reduction greatly affected the temperature at which the inflexion point in the curves appeared, as the presence of sucrose increases the starch gelatinization temperature and protein coagulation temperature (Wootton \& Bamunuarachchi, 1980; Eliasson, 1992; Abd Ghani et al., 1999). In the control batter the inflexion point occurred at approximately 80 ${ }^{\circ} \mathrm{C}$, while $50 \%$ sucrose reduction decreased it to approximately $67^{\circ} \mathrm{C}$ and $100 \%$ reduction to $60{ }^{\circ} \mathrm{C}$. In this regard the erythritol was very successful in mimicking the effect of sucrose, as it increased the temperature at which the inflexion point occurred. The resulting delay, mainly in starch gelatinization, is crucial to avoid earlier thermosetting and give enough time for appropriate air and vapor expansion during baking. In view of its effects on the batter's viscoelastic properties during heating, erythritol could be considered a good candidate to replace sucrose because: 1) it reduces batter elasticity at ambient temperature, simulating the effect of sucrose: in comparison to non sucrose batters, in the presence of erythritol, the values of tan $\delta$ became closer to 1 , indicating an increase in the predominance of the viscous component versus the elastic component, 2) it reduces the decrease in the elastic modulus ( $G$ ') during heating, thus stabilizing the batter structure during this process and 3 ) it increases the thermosetting temperature (value at which the inflexion point in the G' versus temperature curve appeared), thus delaying starch gelatinization and protein coagulation.

\subsubsection{Effect of xanthan gum and a double quantity of leavening agent}

The effect of adding xanthan gum and a double quantity of leavening agent on the erythritol batter's viscoelastic properties during heating can be seen in Figure 2. The temperature at which the elastic modulus ( $\left.G^{\prime}\right)$ started to increase was not altered by the addition of xanthan gum and a double quantity of leavening. The only difference compared to erythritol alone was a slight decrease in the initial $\mathrm{G}^{\prime}$ values $\left(25^{\circ} \mathrm{C}\right)$ in this sample, which achieved the values reached by the control batter. This decrease in G' may be related to the 
double amount of leavening agent, which reduced the batter density by increasing the air content of the batter, as explained below.

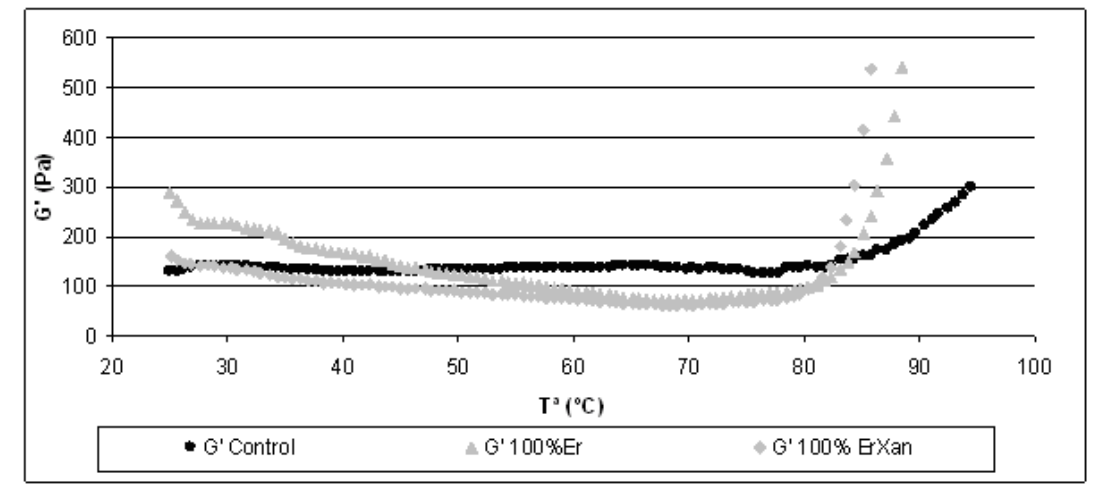

Figure 2. Elastic modulus (G)' as a function of increasing temperature in the Spanish muffin control batter and in batters with sucrose replaced by erythritol alone or erythritol with xanthan gum.

\subsection{Specific gravity (SG) and microstructure of the batter}

\subsubsection{Sucrose reduction and sucrose replacement with erythritol}

Retention of air in batters is reflected by the specific gravity values. Lower specific gravity is associated with higher aeration of the batter (Khalil, 1998), indicating a higher capacity of the batter to incorporate air bubbles during beating and retain them (Bath et al., 1992).

The effect on specific gravity of sucrose reduction and of sucrose replacement with erythritol can be seen in Tables 2 and 3 respectively. Sucrose reduction significantly $(P=0.004)$ increased the $S G$ values (Table 2 ), implying a reduction in the amount of air (less air incorporation or less capacity of the batter to retain air). This reduction in the amount of air may explain the increase in the elastic properties found with sucrose reduction, due to an increase in batter density.

In the batters where sucrose was replaced by erythritol (Table 3 ) the same trend was observed $(P=0.002)$, although less noticeably: for the lower 
replacement levels (25\% and 50\%), the SG values were not significantly different from those of the control.

Table 2. Specific gravity (SG) of batters $(N=4)$ and batter bubbles quantification $(\mathrm{N}=4)$ of the control muffin and of muffins prepared with decreasing quantities of sucrose.

\begin{tabular}{cccccc}
\hline \multirow{2}{*}{$\begin{array}{c}\text { Type of } \\
\text { formula }\end{array}$} & \multirow{2}{*}{$\begin{array}{c}\text { SG } \\
(\mathrm{g} / \mathrm{L})\end{array}$} & $\begin{array}{c}\text { Total } \\
\text { bubbles }\end{array}$ & $\begin{array}{c}\text { Area distribution } \\
\left(\mathrm{m}^{2} \times 10^{-6}\right)\end{array}$ & $\begin{array}{c}\text { Average Size } \\
\left(\mathrm{m}^{2} \times 10^{-6}\right)\end{array}$ \\
\cline { 3 - 5 } & & & $<0.02$ & $>0.02$ & \\
\hline \multirow{2}{*}{ Control } & $0.952 \mathrm{a}$ & $77.00 \mathrm{a}$ & $71.50 \mathrm{a}$ & $4.00 \mathrm{a}$ & $6.42 \times 10^{-3} \mathrm{a}$ \\
& $(0.00)$ & $(14.14)$ & $(17.68)$ & $(1.41)$ & $\left(3.41 \times 10^{-3}\right)$ \\
\hline \multirow{2}{*}{$25 \% \mathrm{SR}$} & $0.979 \mathrm{~b}$ & $34.00 \mathrm{~b}$ & $31.00 \mathrm{~b}$ & $3.00 \mathrm{a}$ & $7.27 \times 10^{-3} \mathrm{a}$ \\
& $(0.00)$ & $(4.24)$ & $(2.83)$ & $(1.41)$ & $\left(1.10 \times 10^{-3}\right)$ \\
\hline \multirow{2}{*}{$50 \% \mathrm{SR}$} & $0.990 \mathrm{~b}$ & $26.50 \mathrm{~b}$ & $25.50 \mathrm{~b}$ & $1.00 \mathrm{a}$ & $6.15 \times 10^{-3} \mathrm{a}$ \\
& $(0.01)$ & $(9.19)$ & $(9.19)$ & $(0.00)$ & $\left(7.93 \times 10^{-4}\right)$ \\
\hline \multirow{2}{*}{$75 \% \mathrm{SR}$} & $0.997 \mathrm{~b}$ & $26.50 \mathrm{~b}$ & $25.00 \mathrm{~b}$ & $1.50 \mathrm{a}$ & $5.13 \times 10^{-3} \mathrm{a}$ \\
& $(0.00)$ & $(6.36)$ & $(5.66)$ & $(0.71)$ & $\left(1.50 \times 10^{-3}\right)$ \\
\hline \multirow{2}{*}{$100 \% \mathrm{SR}$} & $0.995 \mathrm{~b}$ & $16.00 \mathrm{~b}$ & $15.00 \mathrm{~b}$ & $1.00 \mathrm{a}$ & $6.84 \times 10^{-3} \mathrm{a}$ \\
& $(0.01)$ & $(4.24)$ & $(5.66)$ & $(1.41)$ & $\left(6.16 \times 10^{-3}\right)$ \\
\hline
\end{tabular}

Values in parentheses are standard deviations. Means in the same column without a common letter differ $(P<0.05)$ according to the least significant difference multiple range test.

Table 3. Specific gravity (SG) of batters $(\mathrm{N}=4)$ and batter bubbles quantification $(\mathrm{N}=4)$ of the control and the formulas in which sucrose was replaced by erythritol.

\begin{tabular}{lccccc}
\hline & \multicolumn{5}{c}{ Batter } \\
\cline { 3 - 5 } $\begin{array}{c}\text { Type of } \\
\text { formula }\end{array}$ & \multirow{2}{*}{$\begin{array}{c}\text { SG } \\
(\mathrm{g} / \mathrm{L})\end{array}$} & $\begin{array}{c}\text { Total } \\
\text { bubbles }\end{array}$ & $\begin{array}{c}\text { Area distribution } \\
\left(\mathrm{m}^{2} \times 10^{-6}\right)\end{array}$ & $\begin{array}{c}\text { Average Size } \\
\left(\mathrm{m}^{2} \times 10^{-6}\right)\end{array}$ \\
\cline { 3 - 5 } & & & $<0.02$ & $>0.02$ & \\
\hline \multirow{2}{*}{ Control } & $0.95 \mathrm{a}$ & $77.00 \mathrm{a}$ & $71.50 \mathrm{a}$ & $4.00 \mathrm{abc}$ & $6.42 \times 10^{-3} \mathrm{a}$ \\
& $(0.00)$ & $(14.14)$ & $(17.68)$ & $(1.41)$ & $\left(3.41 \times 10^{-3}\right)$ \\
\hline \multirow{2}{*}{$25 \% \mathrm{Er}$} & $0.96 \mathrm{ab}$ & $70.00 \mathrm{a}$ & $57.50 \mathrm{a}$ & $7.50 \mathrm{c}$ & $13.61 \times 10^{-3} \mathrm{a}$ \\
& $(0.00)$ & $(39.60)$ & $(47.38)$ & $(0.71)$ & $\left(9.06 \times 10^{-3}\right)$ \\
\hline \multirow{2}{*}{$50 \% \mathrm{Er}$} & $0.97 \mathrm{ab}$ & $85.50 \mathrm{a}$ & $80.00 \mathrm{a}$ & $5.50 \mathrm{bc}$ & $7.44 \times 10^{-3} \mathrm{a}$ \\
& $(0.00)$ & $(13.44)$ & $(12.73)$ & $(0.71)$ & $\left(1.33 \times 10^{-3}\right)$ \\
\hline \multirow{2}{*}{$75 \% \mathrm{Er}$} & $0.98 \mathrm{bc}$ & $28.50 \mathrm{a}$ & $25.50 \mathrm{a}$ & $3.00 \mathrm{ab}$ & $9.58 \times 10^{-3} \mathrm{a}$ \\
& $(0.01)$ & $(4.95)$ & $(3.54)$ & $(1.41)$ & $\left(3.49 \times 10^{-3}\right)$ \\
\hline \multirow{2}{*}{$100 \% \mathrm{Er}$} & $1.02 \mathrm{c}$ & $13.00 \mathrm{a}$ & $12.00 \mathrm{a}$ & $1.00 \mathrm{a}$ & $7.68 \times 10^{-3} \mathrm{a}$ \\
& $(0.01)$ & $(2.83)$ & $(2.83)$ & $(0.00)$ & $\left(2.62 \times 10^{-3}\right)$ \\
\hline
\end{tabular}

Values in parentheses are standard deviations. Means in the same column without a common letter differ $(P<0.05)$ according to the least significant difference multiple range test. 
The SG values were in agreement with the light micrography images of the batters (Figure 3A and Table 2). A progressive reduction in the number and size of air bubbles was found with the reduction in the sucrose level, implying that sucrose helps to incorporate and retain air during batter mixing. In addition the lower elasticity of the control batter, will offer less resistance to the shearing forces applied during mixing, favoring air entrapment in the batter.

A

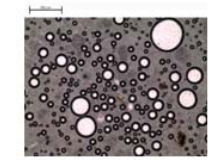

Control

B

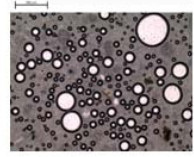

Control

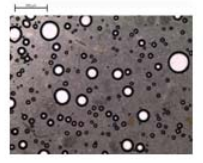

$25 \%$ SR

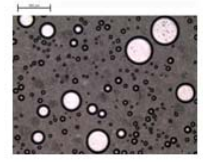

$25 \% \mathrm{Er}$

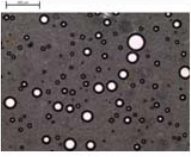

$50 \%$ SR

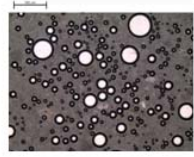

$50 \% \mathrm{Er}$

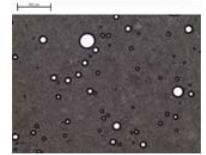

$75 \% \mathrm{SR}$

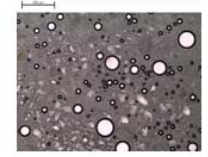

$75 \% \mathrm{Er}$

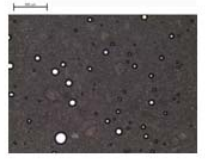

$100 \%$ SR

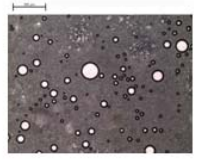

$100 \% \mathrm{Er}$

Figure 3. Light microscopy images of the different batters (x40). A: control batter and reduced sucrose batters and $B$ : control batter and sucrose replaced by erythritol batters. The scale was equivalent to $500 \mu \mathrm{m}$.

The micrographs of the batters in which sucrose was replaced by erythritol also reflected a decrease in the number and size of air bubbles as the sucrose was reduced (Figure $3 \mathrm{~B}$ and Table 3 ). However, this decrease was slightly lower than in the reduced sucrose batters, which implies that erythritol had an effect on the batter's air-holding capacity. Indeed, the number and size of bubbles in the $25 \% \mathrm{Er}$ and $50 \% \mathrm{Er}$ batters was very similar to those of the control formulation. Lin et al. (2003) did not find significant differences in specific gravity values when sucrose was replaced by erythritol in cakes. On the other hand, Kim \& Walker (1992) observed that when $50 \%$ of sucrose was replaced by lactose the specific gravity decreased, indicating that lactose appeared to exert a surfactant function. In the present case, the increase in specific gravity correlates to the light micrographs of the batter (Figure 3B), 
which show a reduction in both the number and size of bubbles in the $75 \% \mathrm{Er}$ and $100 \%$ Er formulations.

\subsubsection{Effect of xanthan gum and double quantities of leavening agent}

The effect of xanthan gum and a double quantity of leavening agent on the SG of the batters can be seen in Table 4. The addition of xanthan gum and doubling of the leaving agent resulted in an increase in the total amount of air in the batter compared to the control and erythritol muffin batters, as reflected by the significant $(P=0.000)$ decrease in the $S G$ of all the xanthan gum batters in comparison with the control (Table 4). Observation of the batter microstructure revealed that adding xanthan gum and doubling the leavening increased the size of the air bubbles compared to the control batter (Figure 4 and Table 4). In comparison with the erythritol batter (Figure 3B), it increased both the number and the size of the air bubbles.

Table 4. Specific gravity (SG) of batters $(N=4)$ and batter bubbles quantification $(\mathrm{N}=4)$ of the two controls formulations and the formulas in which sucrose was replaced by erythritol and xanthan gum.

\begin{tabular}{lccccc}
\hline & \multicolumn{5}{c}{ Batter } \\
\cline { 2 - 5 } $\begin{array}{c}\text { Type of } \\
\text { formula }\end{array}$ & $\begin{array}{c}\text { SG } \\
\text { (g/L) }\end{array}$ & $\begin{array}{c}\text { Total } \\
\text { bubbles }\end{array}$ & $\begin{array}{c}\text { Area distribution } \\
\left(\mathrm{m}^{2} \times 10^{-6}\right)\end{array}$ & $\begin{array}{c}\text { Average Size } \\
\left(\mathrm{m}^{2} \times 10^{-6}\right)\end{array}$ \\
\cline { 3 - 5 } & & & $<0.02$ & $>0.02$ & \\
\hline \multirow{2}{*}{ Control } & $0.95 \mathrm{a}$ & $77.00 \mathrm{a}$ & $71.50 \mathrm{a}$ & $4.00 \mathrm{a}$ & $6.42 \times 10^{-3} \mathrm{a}$ \\
& $(0.00)$ & $(14.14)$ & $(17.68)$ & $(1.41)$ & $\left(3.41 \times 10^{-3}\right)$ \\
\hline \multirow{2}{*}{ Control Xan } & $0.84 \mathrm{~b}$ & $66.50 \mathrm{ab}$ & $57.00 \mathrm{ab}$ & $8.50 \mathrm{a}$ & $14.37 \times 10^{-3} \mathrm{ab}$ \\
& $(0.00)$ & $(0.71)$ & $(0.00)$ & $(0.71)$ & $\left(2.60 \times 10^{-3}\right)$ \\
\hline \multirow{2}{*}{$25 \%$ ErXan } & $0.85 \mathrm{~b}$ & $69.50 \mathrm{ab}$ & $57.50 \mathrm{ab}$ & $12.00 \mathrm{a}$ & $13.25 \times 10^{-3} \mathrm{ab}$ \\
& $(0.00)$ & $(7.78)$ & $(2.12)$ & $(5.66)$ & $\left(3.97 \times 10^{-3}\right)$ \\
\hline \multirow{2}{*}{$50 \%$ ErXan } & $0.85 \mathrm{~b}$ & $50.00 \mathrm{ab}$ & $35.50 \mathrm{~b}$ & $14.50 \mathrm{a}$ & $23.41 \times 10^{-3} \mathrm{~b}$ \\
& $(0.00)$ & $(4.24)$ & $(0.71)$ & $(3.54)$ & $\left(9.36 \times 10^{-3}\right)$ \\
\hline \multirow{2}{*}{$75 \%$ ErXan } & $0.84 \mathrm{~b}$ & $66.00 \mathrm{ab}$ & $59.00 \mathrm{ab}$ & $7.00 \mathrm{a}$ & $11.48 \times 10^{-3} \mathrm{a}$ \\
& $(0.01)$ & $(4.24)$ & $(0.00)$ & $(4.24)$ & $\left(2.58 \times 10^{-3}\right)$ \\
\hline \multirow{2}{*}{$100 \%$ ErXan } & $0.87 \mathrm{~b}$ & $47.50 \mathrm{~b}$ & $4.00 \mathrm{ab}$ & $3.50 \mathrm{a}$ & $7.32 \times 10^{-3} \mathrm{a}$ \\
& $(0.02)$ & $(0.71)$ & $(1.14)$ & $(2.12)$ & $\left(3.08 \times 10^{-3}\right)$ \\
\hline
\end{tabular}

Values in parentheses are standard deviations. Means in the same column without a common letter differ $(P<0.05)$ according to the least significant difference multiple range test. 
The xanthan gum batters contained medium and large size bubbles while those without xanthan gum had smaller bubbles or, at high replacement levels, the air bubbles disappeared (Table 4). The higher number of air bubbles could be explained by the larger amount of leavening agent in the formula.

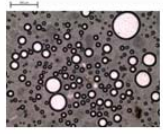

Control

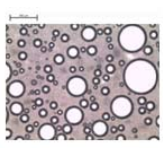

Control Xan

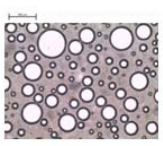

$25 \%$ ErXan

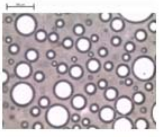

$50 \%$ ErXan

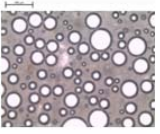

$75 \%$ ErXan

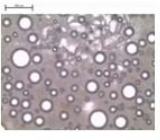

$100 \%$ ErXan

Figure 4. Light microscopy images of the control batter and of the sucrose replaced by erythritol and xanthan gum batters $(x 40)$. The scale was equivalent to $500 \mu \mathrm{m}$.

3.3. Bubbles in the crumb and muffin height, volume and weight loss

\subsubsection{Sucrose reduction and sucrose replacement with erythritol}

The images of the muffin crumb of the reduced sucrose muffins and those with sucrose replaced by erythritol are shown in Figure $5 \mathrm{~A}$ and $5 \mathrm{~B}$ respectively and total bubbles, distribution and average size are shown in Tables 5 and 6 respectively. The crumb structure was affected to an extreme extent by eliminating sucrose from the formula (Figure 5A and Tables 5). The control crumb possessed large and small air bubbles, which conferred an appearance of springiness. The elimination of sucrose caused larger bubbles to appear. The $100 \%$ SR muffin crumb had very few small bubbles and many large bubbles. These large bubbles formed tunnels from the base to the surface, so some air was lost during the formation of the crumb structure. This effect may be related to the fact that sucrose elimination reduces the viscosity of the liquid phase around the air bubbles, increasing air bubble mobility and coalescence. A further reason for this crumb structure is the early thermosetting of the batter during the heating process in the oven: since the gas generated by the 
leavening agent and the water vapor did not have time to expand, it collapsed and led to the appearance of large bubbles. The decrease in air bubble expansion was associated with a significant decrease in height $(P=0.000)$ and volume $(P=0.000)$ as the sucrose was reduced (Table 5).

A
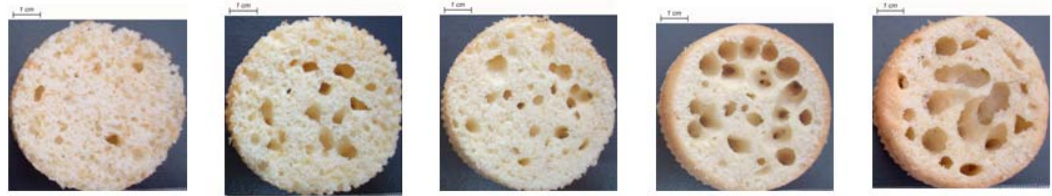

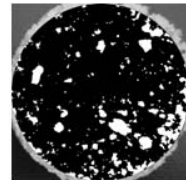

Control

B
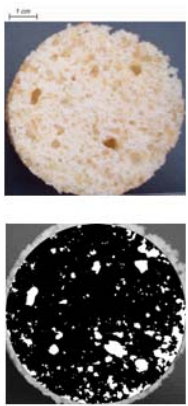

Control

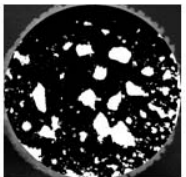

$25 \%$ SR
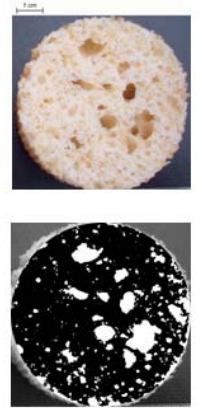

$25 \% \mathrm{Er}$

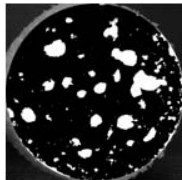

$50 \%$ SR
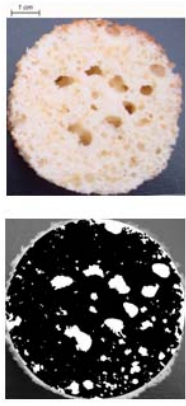

$50 \% \mathrm{Er}$

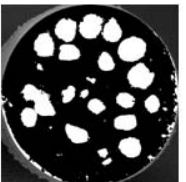

$75 \%$ SR
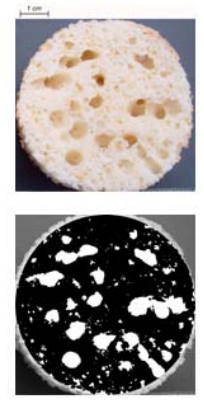

$75 \% \mathrm{Er}$

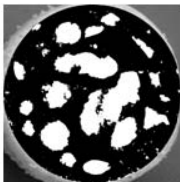

$100 \%$ SR
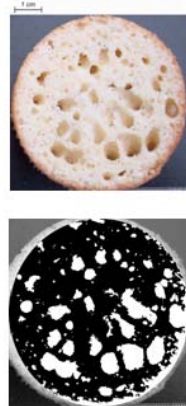

$100 \% \mathrm{Er}$

Figure 5. Photographs of transverse sections of the different muffins. A: control and sucrose reduced muffins and $B$ : control and sucrose replaced by erythritol muffins. The scale was equivalent to $1 \mathrm{~cm}$.

Sucrose plays an important role in water retention in muffins, decreasing moisture loss during baking. As the sucrose was eliminated the weight loss progressively increased; the differences compared to the control muffin were significant $(P=0.000)$ for the $75 \%$ and $100 \%$ sucrose reduction levels. 


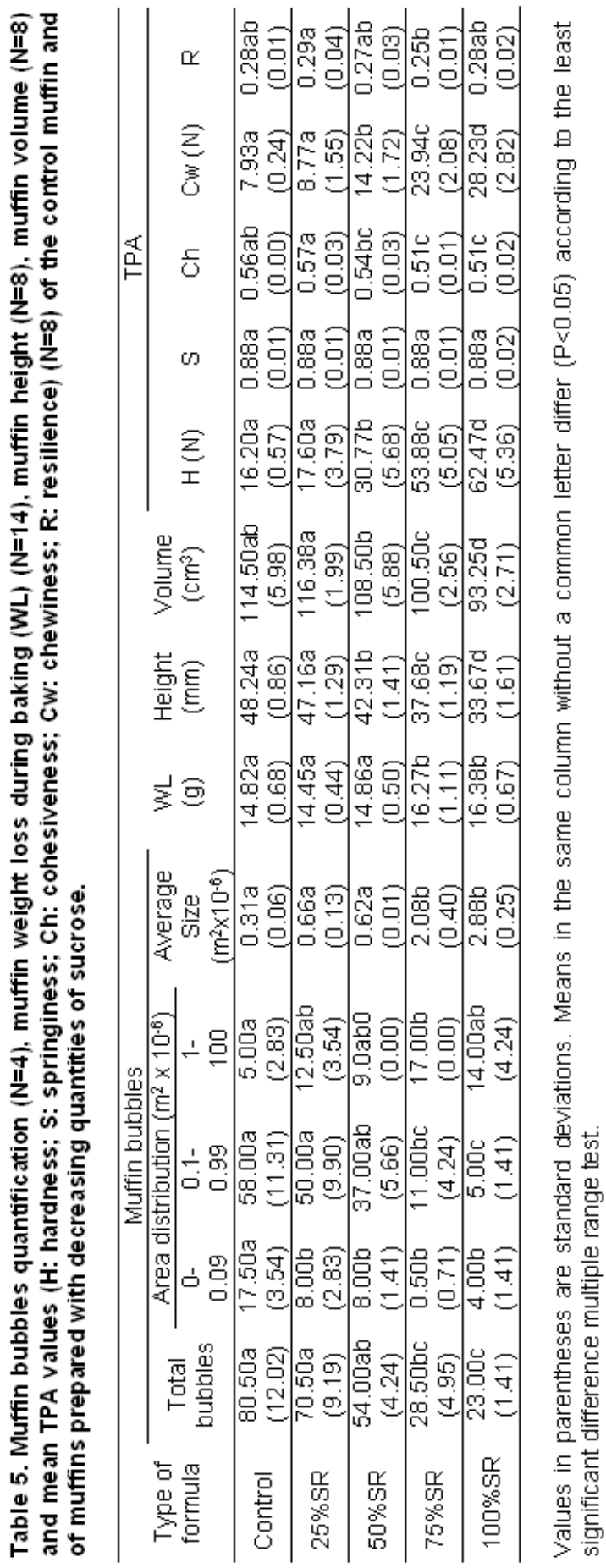




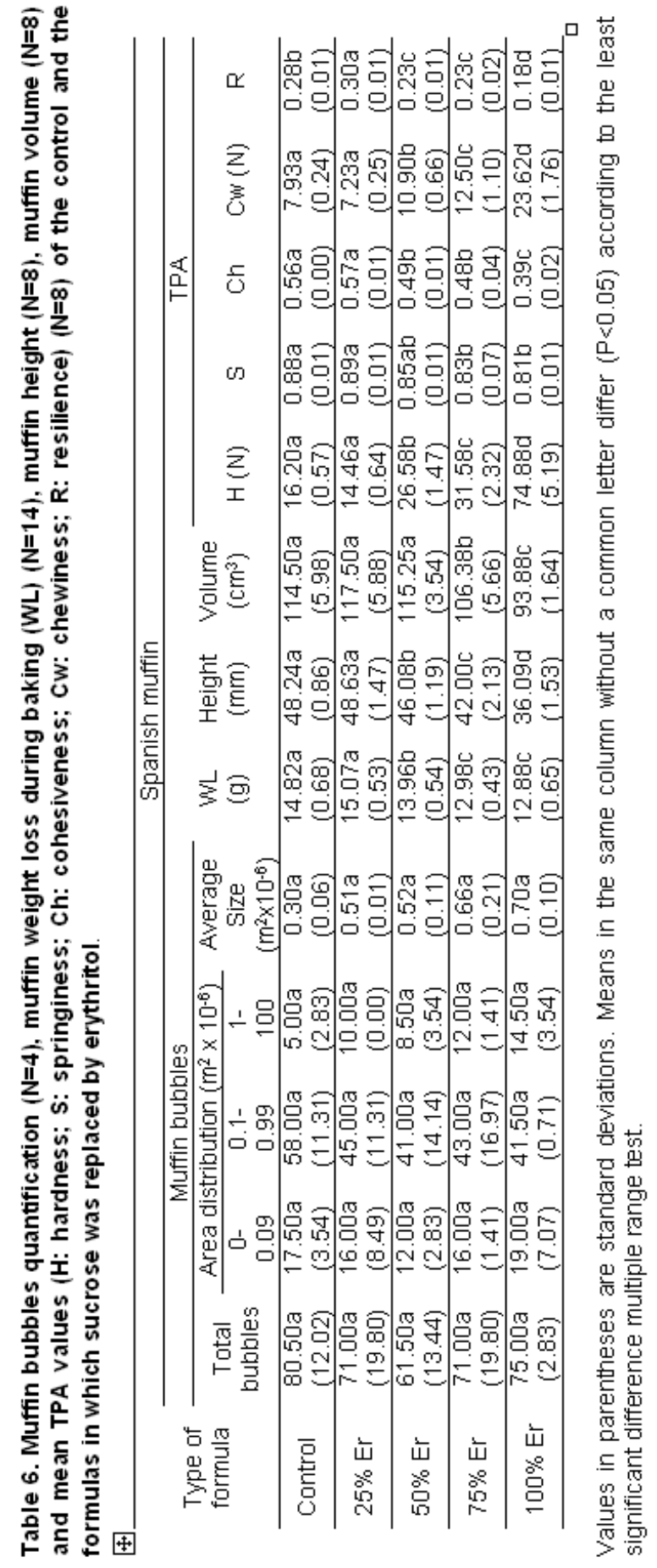


The effect of erythritol can be seen in Figure 5B (crumb bubbles) and in Table 6 (total bubbles, bubbles distribution, average size of bubbles, muffin height, volume and weight loss).

The images of the crumb showed that the erythritol samples also differed from the control sample, with the bubbles becoming larger as the amount of sucrose replacement increased; the $75 \% \mathrm{Er}$ and $100 \% \mathrm{Er}$ samples contained larger bubbles than the control sample. However, the crumb structure bore a greater resemblance to that of the control than in the sucrose reduction samples, implying that erythritol was conferring some of the structural effects provided by sucrose. The height $(P=0.000)$ and volume $(P=0.000)$ of the muffins also increased in the presence of erythritol in comparison with the equivalent sucrose reduction muffins. Erythritol also reduced weight loss during baking $(P=0.000)$ (Table 6$)$. In the erythritol muffins, weight loss during baking was lower than in the control muffins. It would appear that erythritol works as a humectant and prevents water from escaping during baking. Similarly, the polyol sorbitol is used in the food industry for its water retention properties (Multon, 1999).

This improvement in the crumb structure associated with the use of erythritol can be related to the erythritol and control batters' having similar viscoelastic properties.

As explained above, the effect of erythritol on the batter structure during heating was similar to that of sucrose.

\subsubsection{Effect of xanthan gum and double quantities of leavening agent}

The photographs of the muffin crumb with xanthan gum and a double quantity of leavening agent are shown in Figure 6 and total bubbles, distribution and average size are shown in Table 7.

When xanthan gum was added and the leavening agent doubled, the crumb structure of the erythritol muffins became more similar to that of the control. For all the replacement levels, the samples contained bubbles of different sizes, evenly distributed. In the absence of xanthan gum and double 
amounts of leavening, the crumbs where more than $50 \%$ sucrose was replaced by Er only showed medium and large size bubbles, with no small ones (Figure 5B).

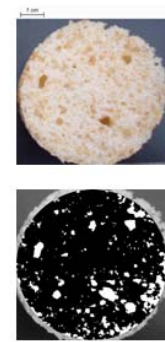

Control
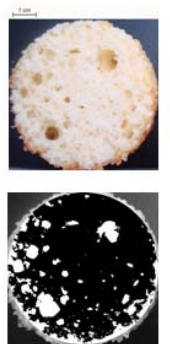

Control Xan
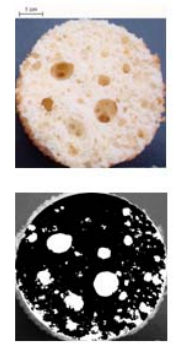

$25 \%$ Erxan
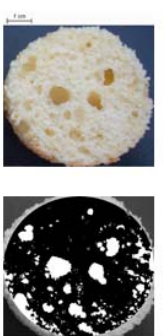

$50 \%$ Erxan
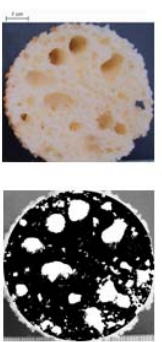

$75 \%$ ErXan
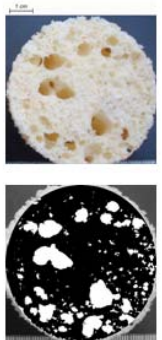

$100 \%$ ErXan

Figure 6. Photographs of transverse sections of control muffin, control muffin with xanthan gum and muffin with sucrose replaced by erythritol and xanthan gum. The scale was equivalent to $1 \mathrm{~cm}$.

The increase in bubble stability associated with the presence of xanthan gum was also associated with an increase in muffin volume (Table 7). Xanthan gum increased the batter viscosity and therefore decreased the mobility of the air bubbles, so less coalescence occurred. In the presence of xanthan gum and double quantities of leavening agent, no significant differences $(P=0.09)$ were found between any of the erythritol-xanthan gum muffins and the control muffin.

The muffin height also increased in the control muffin but no improvement in muffin height was found in the erythritol muffins. Adding xanthan gum to the control muffin and doubling the leavening agent slightly $(P=0.000)$ increased the weight loss during baking. This can be related to the increased volume of the muffins, which means that a greater surface area is available for water evaporation. In the erythritol muffins, the addition of xanthan gum and a double quantity of leaving agent conferred a similar weight loss to the control muffin, so this combination counterbalances the decrease in weight loss attributed to the erythritol. 


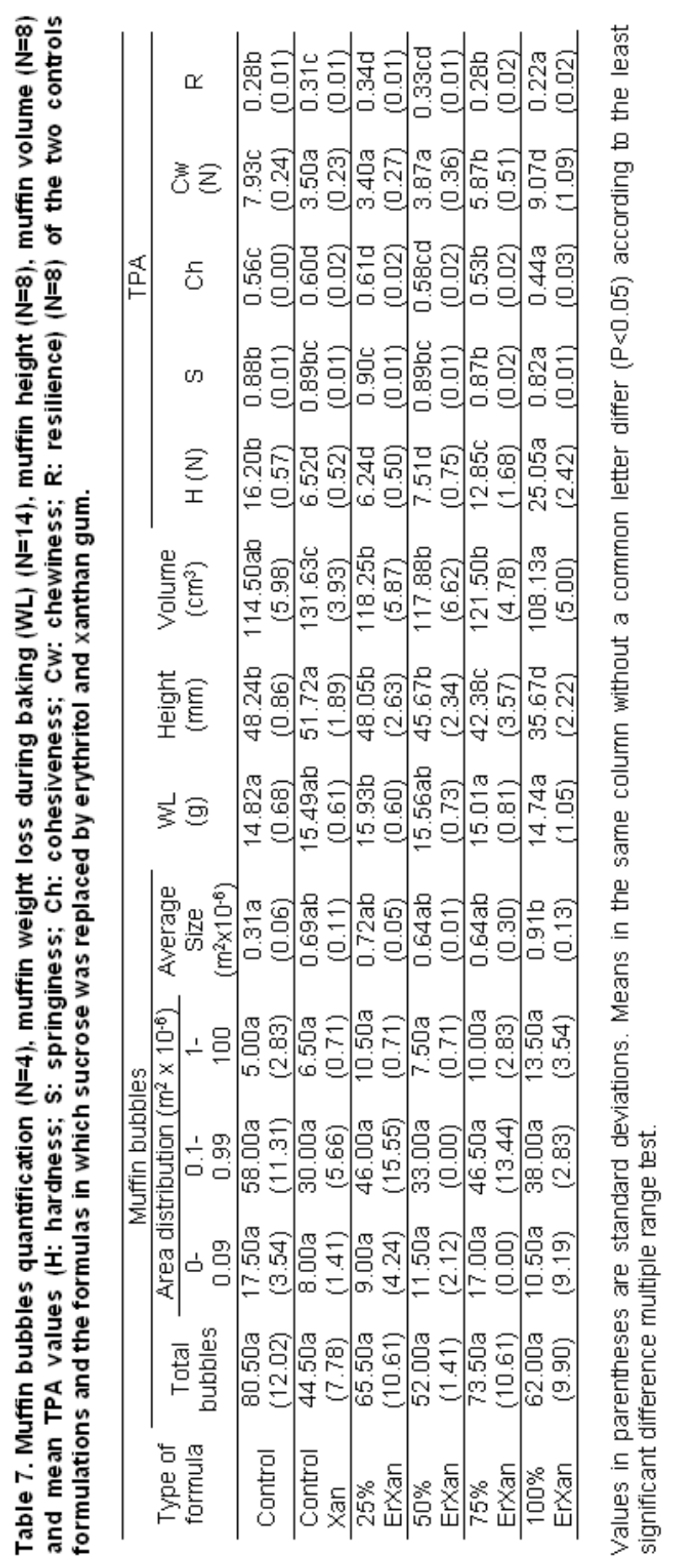




\subsection{Muffin texture}

\subsubsection{Sucrose reduction and sucrose replacement with erythritol}

The parameters obtained from the texture profile analysis are shown in Table 5 (reduced sucrose muffins) and Table 6 (muffins with sucrose replaced by erythritol). The elimination of sucrose had a considerable effect on the hardness of the muffins. $50 \%$ reduction of sucrose gave samples with a significant increase in hardness $(P=0.000)$, which can be related to a decrease in muffin volume. This inverse relationship between hardness and volume has also been observed in layer cakes (Gómez et al., 2010). The same behaviour applied to chewiness $(P=0.000)$, which is a secondary texture parameter associated with difficulty in chewing the sample and forming a bolus before swallowing and is related to hardness, springiness and cohesiveness (Table 5). Springiness $(P=0.498)$ and resilience $(P=0.000)$ were not affected by sucrose reduction but cohesiveness decreased significantly $(P=0.000)$ when more than $75 \%$ of sucrose was removed (Table 5 ).

The erythritol muffins also showed significantly different hardness $(P=0.000)$ values compared to the control. It was only for $25 \%$ sucrose replacement with erythritol that no significant differences were found. Chewiness followed the same trend as hardness, as can be seen in Table 6. On the other hand, springiness $(P=0.000)$, cohesiveness $(P=0.000)$ and resilience $(P=0.000)$ decreased when at least $50 \%$ of the sucrose was replaced by erythritol, reflecting a more compact crumb (Table 6). Similar results were found by Akesowan (2009) in chiffon cake when sucrose was replaced by a sucralose-erythritol mixture. Barndt \& Antenucci (1993) associated the tenderizing effect on muffin texture obtained when sucrose was removed to the suppressing effect of sugar on starch gelatinization. As shown in Table 2, sucrose reduction significantly increased the $S G$ values $(P=0.004)$, implying a reduction in the amount of air. Together with the earlier thermosetting during baking that resulted in denser masses, this was related to lower resilience values, meaning that it takes longer for the structure of the muffin to recover after compression. 


\subsubsection{Effect of xanthan gum and double quantities of leavening agent}

When sucrose was replaced by erythritol the hardness $(P=0.000)$ and chewiness $(P=0.000)$ values were significantly higher than for the control, but when the formulation was improved with the addition of xanthan gum and double quantities of leavening agent the hardness $(P=0.000)$ and chewiness $(P=0.000)$ values were lower than those of the control muffins (Table 7$)$. Since Gómez et al. (2007) observed an increase in hardness when xanthan gum was added to layer cakes, the decrease in hardness found with the addition of xanthan gum and a double quantity of leavening must mainly be associated with the increased amount of leavening agent rather than with the added xanthan gum.

Cohesiveness decreased in the $\mathrm{Er}$ formulations $(P=0.000)$ but the ErXan formulation showed similar values to the control muffins $(P=0.000)$. The same behaviour was observed with the springiness values of the $\operatorname{Er}(P=0.000)$ and ErXan muffins $(P=0.000)$. The resilience values were lower $(P=0.000)$ in all the formulations except $25 \% \mathrm{Er}$ and $75 \% \mathrm{ErXan}$, where the values were similar to the control muffins, and $25 \% \mathrm{ErXan}$ and $50 \% \mathrm{ErXan}$, which obtained higher values (Table 7).

To summarize, adding xanthan gum and doubling the leaving agent clearly improved the texture defects associated with the erythritol muffins. In comparison with the control, hardness $(P=0.000)$ and chewiness $(P=0.000)$ were significantly reduced and springiness $(P=0.000)$ and cohesiveness $(P=0.000)$ were slightly increased.

\subsection{Muffin color}

The crust and crumb colors were somewhat affected by the reduction or removal of sucrose. The crust of the control muffin presented lower lightness values (data not shown) due to reactions between the sugar and proteins, leading to the formation of brown compounds. When sucrose is reduced or removed, these Maillard reactions are reduced and no brown compounds are 
generated. The control muffin crusts also had the highest redness $\left(a^{*}\right)$ and smallest $b^{*}$ values. No significant differences were found in crumb color parameters $(P=0.527)$

In the muffins containing erythritol the color followed the same behaviour pattern as in the reduced sucrose muffins because erythritol is not involved in Maillard reactions. Lin et al. (2003) obtained similar results in chiffon cake when sucrose was replaced by erythritol. The crust color of the erythritol cakes was lighter and less red than that of all the other cakes $(P=0.000)$. Again, the crumb color was not affected $(P=0.573)$.

The incorporation of xanthan gum and double quantities of leavening agent did not cause significant differences in color parameters.

\section{Conclusions}

Erythritol was able to partially simulate sucrose functionality in Spanish muffins, producing an increase in the air content of the batter and in muffin height and number of bubbles in comparison with the corresponding reduced sucrose muffins. The positive effect of erythritol on muffin properties can be associated with the fact that erythritol, like sucrose, reduces the decrease in elasticity during heating and raises the thermosetting temperature. However, the effect of the erythritol was not enough to improve the volume $(P=0.000)$ and texture $(P=0.000)$ of the muffins.

The combination of erythritol with xanthan gum and double quantities of leavening agent was effective in improving the texture properties of the muffins, reducing their hardness $(P=0.000)$; this was associated with a significant increase in batter air content $(P=0.000)$ and in muffin height $(P=0.000)$, volume $(P=0.000)$ and number of bubbles $(P=0.032)$ in comparison with the employment of erythritol alone. 


\section{References}

Abd Ghani MB, Che Man YB, Ali AB \& Mat Hashim DB (1999) Differential scanning calorimetry: gelatinisation of sago starch in the presence of sucrose and sodium chloride. Journal of the Science of Food and Agriculture 79, 2001-2009.

Akesowan A (2009) Quality of reduced-fat chiffon cakes prepared with erythritol-sucralose as replacement for sugar. Pakistan Journal of Nutrition 8 (9), 1383-1386.

Ashwini A, Jyotsna R \& Indrani D (2009) Effect of hydrocolloids and emulsifiers on the rheological, microstructural and quality characteristics of eggless cake. Food Hydrocolloids 23, 700-707.

Baeva MR, Terzieva VV \& Panchev IN (2003) Structural development of sucrose-sweetened and sucrose-free sponge cakes during baking. Nahrung/Food 47 (3), 154-160.

Barndt RL \& Antenucci RN (1993) Fat and Calorie Modified Bakery Products. En: Low-Calorie Foods and Food Ingredients (pp: 106-137). Editado por: Khan R. Blackie Academic and Professional (London, UK).

Bath DE, Shelke K \& Hoseney RC (1992) Fat replacers in high-ratio layer cakes. Cereal Foods World 37 (7), 495-500.

Beesley PM (1995) Sugar functionality reviewed. Food Technology International Europe, 87-89.

Bodart M, de Peñaranda R, Deneyer A \& Flamant G (2008) Photometry and colorimetry characterisation of materials in daylighting evaluation tools. Building and Environment 43, 2046-2058.

Eliasson AC (1992) A calorimetric investigation of the influence of sucrose on the gelatinization of starch. Carbohydrate Polymers 18 (2), 131-138.

Francis FJ \& Clydesdale FM (1975) Color differences. En: Food Colorimetry: Theory and Applications (pás. 143-151). Editado por: FJ Francis \& FM Clydesdale. The Avi publishing company, Inc (Westport, Connecticut). 
Gómez M, Ronda F, Caballero PA, Blanco CA \& Rosel CM (2007). Functionality of different hydrocolloids on the quality and shelf-life of yellow layer cakes. Food Hydrocolloids 21, 167-173.

Gómez M, Ruiz-Paris E, Oliete B \& Pando V (2010) Modelling of texture evolution of cakes during storage. Journal of Texture Studies 41, 17-33.

Goossens J \& Roeper H (1994) Erythritol: a new sweetener. Food Science \& Technology Today 8 (3), 144-148.

Haji F (2009) Erythritol: a natural innovation. Agro Food Industry hi-tech 20 (3), 36-37.

Kamel BS \& Rasper VF (1988) Effects of emulsifiers, sorbitol, polydextrose and crystalline cellulose on the texture of reduced-calorie cakes. Journal of Texture Studies 19 (3), 307-320.

Khalil AH (1998) The influence of carbohydrate-based fat replacers and with and without emulsifiers on the quality characteristics of low fat cake. Plant Foods for Human Nutrition 52, 299-313.

Khouryieh HA, Aramouni FM \& Herald TJ (2005) Physical and sensory characteristics of no-sugar-added / low-fat muffin. Journal of Food Quality 28 (5-6), 439-451.

Kim CS \& Walker CE (1992) Interactions between starches, sugars, and emulsifiers in high-ratio cake model system. Cereal Chemistry 69, 206212.

Kissell LT \& Bean MM (1978) AACC Technical Committee Report: Development of a method for angel food cake. Cereal Foods World 23 (3), 136-142.

Lin SD, Hwang CF \& Yeh CH (2003) Physical and sensory characteristics of chiffon cake prepared with erythritol as replacement for sucrose. Journal of Food Science 68 (6), 2107-2110.

Miller RA \& Hoseney RC (1993) The role of xanthan gum in white layer cakes. Cereal Chemistry 70 (5), 585-588.

Multon JL (1999) En: Aditivos y auxiliares de fabricación en las Industrias Agroalimentarias. Editado por: JL Multon. Acribia (Zaragoza). 
Ngo WH \& Taranto MV (1986) Effect of sucrose level on the rheological properties of cake batters. Cereal Foods World 31 (4), 317-322.

Noda K, Nakayama K \& Oku T (1994) Serum glucose and insulin levels and erythritol balance after oral administration of erythritol in healthy subjects. European Journal of Clinical Nutrition 48, 286-292.

Oku T \& Noda K (1990) Influence of chronic ingestion of newly developed sweetener erythritol on growth and gastrointestinal function of the rats. Nutrition Research 10 (10), 987-996.

Olinger PM \& Velasco VS (1996) Opportunities and advantages of sugar replacement. Cereal Foods World 41 (3), 110-117.

Ronda F, Gómez M, Blanco CA \& Caballero PA (2005) Effects of polyols and nondigestible oligosaccharides on the quality of sugar-free sponge cakes. Food Chemistry 90 (4), 549-555.

Ronda F, Gómez M, Caballero PA, Oliete B \& Blanco CA (2009) Improvement of quality of gluten-free layer cakes. Food Science and Technology International 15 (2), 193-202.

Shelke K, Faubion JM \& Hoseney RC (1990) The dynamics of cake baking as studied by a combination of viscometry and electrical resistance oven heating. Cereal Chemistry 67(6), 575-580.

Tetzloff W, Dauchy F, Medimagh S, Carr D \& Bär A (1996) Tolerance to subchronic, high-dose ingestion of erythritol in human volunteers. Regulatory Toxicology and Pharmacology 24, S286-295.

Turabi E, Sumnu G \& Sahin S (2008) Rheological properties and quality of rice cakes formulated with different gums and an emulsifier blend. Food Hydrocolloids 22, 305-312.

Wootton M \& Bamunuarachchi A (1980) Application of differential scanning calorimetry to starch gelatinisation. III. Effect of sucrose and sodium chloride. Starch/Stärke 32, 126-129. 


\section{CAPÍtULO 3}

COMPARISON OF DIFFERENT POLYOLS AS TOTAL

SUCROSE REPLACERS IN MUFFINS: THERMAL, RHEOLOGICAL, TEXTURE AND ACCEPTABILITY

PROPERTIES

Martínez-Cervera S, Salvador A \& Sanz T

FOOD HYDROCOLLOIDS (2013) (ENVIADO). 



\section{Abstract}

The aim of this work was to compare the suitability of different polyols (sorbitol, maltitol, isomalt and erythritol) as total sucrose replacers in muffins. Thermal and rheological properties of the batters and muffin texture, height and consumer acceptability were evaluated.

As sucrose, all the polyols increased the starch gelatinization temperature, although differences were found among them, being erythritol the less effective. The batter rheological properties also revealed that erythritol showed the highest differences with sucrose, in comparison to the other polyols.

All the polyol muffins showed lower height than the sucrose muffins. The effect in muffin texture parameters was dependent on the type of polyol. In comparison to sucrose, erythritol increased the hardness and sorbitol and maltitol decreased it. Isomalt confered similar texture parameters than sucrose. No differences were found in sensory acceptance among sucrose, sorbitol and maltitol muffins.

Keywords: Sucrose; polyols; muffins; sweeteners; DSC; rheology 


\section{Introduction}

Spanish muffins are sweet, high-calorie baked products which are highly appreciated by consumers due to their good taste and soft texture. Spanish muffin batter is a complex fat-in-water emulsion. The final product is characterized by a typical porous structure and high specific volume, which confers a spongy texture. Shortening and oil are used to give a softer structure and to avoid a dry mouth feel. Sucrose contributes to the sweet taste, provides a considerable part of the bulk in batters, helps baked goods stay moist, and limits the swelling of starch, which helps to create a finer texture (Beesley, 1995). Under non-acidic conditions, it contributes to the browning not only of the crust but also of the crumb. One important role of sucrose is to raise starch gelatinization and protein denaturation temperatures during cake baking. Furthermore, sucrose promotes fat-crystal aggregates, thus enhancing air entrapment and the stabilization of air bubbles during baking (Beesley, 1995).

Sucrose has a high glycemic index and for this reason diabetic people should not consume large quantities of typical bakery products. For this reason, the products suitable for diabetics contain sucrose substitutes. Due to the complex structural functionality of sucrose in baked products, obtaining good quality low-sucrose products is a difficult task. Sugar alcohols or polyols are typical sucrose replacers in baked goods (Olinger \& Velasco, 1996) and their properties have been studied by many authors (Kamel \& Rasper, 1988; Baeva, Terzieva \& Panchev, 2003; Ronda et al., 2005). Polyols are used in food products in which the volume, the texture and the sweetness provided by sucrose are important, such as muffins. Polyols present three potential advantages over sucrose as food ingredients. First, they do not promote the development of dental caries because dental bacteria are not able to can not ferment the sugar alcohols. Second, they produce a lower glycemic response than sucrose and are therefore suitable for diabetics. And third, most polyols are lower in calories than sucrose (Kroger et al., 2006). Thus, sorbitol has only $2.6 \mathrm{Kcal} / \mathrm{g}$, maltitol $2.1 \mathrm{Kcal} / \mathrm{g}$, isomalt $2.0 \mathrm{Kcal} / \mathrm{g}$ and erythritol $0.2 \mathrm{Kcal} / \mathrm{g}$ 
compared to sucrose that provides $4 \mathrm{Kcal} / \mathrm{g}$. One disadvantage of polyols is the flatulence they produce, as a result of their fermentation by colonic bacteria. McNutt \& Sentko (1996) demonstrated large differences in polyols tolerance between individuals, some people needing to gradually adapt to higher intakes of polyols. Thus, the tolerance of these people increased by eating small amounts of polyols during a few days of adaptation and thereon they could consume large amounts of polyols without discomfort.

Sorbitol (Sor) is produced industrially by hydrogenation of glucose derived from starch and from inverted sugar (Bornet, 1994) and it presents about $60 \%$ of the sweetness of sucrose (Zumbé, Lee \& Storey, 2001). Maltitol (Mlt) does not occur in nature and it is obtained by hydrogenation of maltose (Bornet, 1994) being about $90 \%$ of the sweetness of sucrose (Zumbé, Lee \& Storey, 2001). Isomalt (Iso) is an equimolar mixture of two disaccharide alcohols, alpha-D-glucopyranosyl-alpha-(1-6)-sorbitol and alpha-Dglucopyranosyl-alpha-(1-6)-mannitol. It is obtained industrially by catalytic hydrogenation of isomaltulose (Bornet, 1994) and it presents about 50\% of the sweetness of sucrose (Zumbé, Lee \& Storey, 2001). Erythritol (Er) plays a similar role to sucrose providing some of the sucrose properties in bakery products (Haji, 2009). Erythritol is a 4-carbon sugar alcohol with about $60 \%$ to $80 \%$ of the sweetness of sucrose (Goossens \& Roeper, 1994) which is obtained via a natural fermentation process (Haji, 2009). Erythritol is a novel bulk sweetener and erythritol's metabolic profile is unique. Moreover, it has a high digestive tolerance due to the lack of a laxative effect.

Different workers have studied the polyols as sucrose replacers in bakery products. Lin, Hwang and Yeh (2003) studied the sensory quality and physical characteristics of chiffon cake with replacement of sucrose by erythritol, obtaining comparable results to cake prepared with $100 \%$ sucrose. Akesowan (2009) studied the replacement of sucrose by a mixture of erythritol and sucralose in reduced fat chiffon cakes and obtained acceptable sensory quality in a $50 \%$ erythritol-sucrose chiffon cake; although a $50 \%$ erythritolsucrose system is not suitable for diabetic products. Lee \& Oh (2010) studied 
the effect of $50 \%$ replacement of sucrose by erythritol, sorbitol or xylitol on cake quality. They observed differences in thermal properties, viscosity, moisture content, specific volume, volume index, symmetry index, color, microstructure, texture and sensory analysis. Ronda et al. (2005) studied the effect on the sensory evaluation and physical measurements of texture, color and specific volume of sucrose replacement by maltitol, mannitol, xylitol, sorbitol, isomaltose, polydextrose and oligofructose in sucrose free cakes. However, these studies have been based in sensory and texture properties but an exhaustive study about the differences among polyols and sucrose in thermal and rheological properties has not been made before.

The aim of this work was to evaluate the effect of sucrose replacement by erythritol, sorbitol, maltitol and isomalt on the batter properties (thermal properties, starch gelatinization and rheology) with the objective of explaining the texture and sensory properties of the muffins.

\section{Materials and methods}

\subsection{Batter preparation}

Five muffin formulations (Table 1) were prepared by replacing all of the sucrose with erythritol (Er) (Zerose Tm 16957 from Cargill Ibérica, S.L., Spain), isomalt (Iso) (C*IsoMaltidex 16502 from Cargill Ibérica, S.L., Spain), maltitol (MIt) (C*Maltidex CH 16385 from Cargill Ibérica, S.L., Spain) or sorbitol (Sor) (C*Sorbidex S 16603 from Cargill Ibérica, S.L., Spain). The Spanish muffin ingredients were wheat flour (Belenguer S.A., Spain. Information provided by the supplier: $\leq 15 \%$ moisture, $10 \%$ proteins), pasteurized liquid egg yolk and pasteurized liquid egg white (Ovocity, Spain), refined sunflower oil (Coosur S.A., Spain), whole milk (Puleva, Spain), sucrose (Azucarera Ebro, Spain), sodium bicarbonate (Martínez, Cheste, Spain), citric acid (Martínez, Cheste, Spain) and salt (sodium chloride).

The batter was prepared in a mixer (Kenwood Major Classic, UK), in which the egg whites were whisked for 2 minutes at top speed (580 rpm). The 
sucrose or polyols (depending on the formulation) were added and mixed in for 30 seconds more at top speed. The egg yolk, half the milk and the citric acid were then added and the mixer was set to speed $3(260 \mathrm{rpm})$ for 1 minute. The flour, sodium bicarbonate and salt were added and the mixture was beaten for a further 1 minute at speed $3(260 \mathrm{rpm})$. Lastly, the mixer speed was increased to speed $4(320 \mathrm{rpm})$, the rest of the milk was added and the oil was gradually dripped in. The mixture was beaten for 3 minutes at speed 4 (320 rpm) until it was smooth.

Table 1. Muffin formulations.

\begin{tabular}{llllll}
\hline \multicolumn{1}{c}{$\begin{array}{c}\text { Ingredients } \\
\text { (g/100 g flour) }\end{array}$} & Suc & Er & Iso & Mlt & Sor \\
\hline Flour & 100 & 100 & 100 & 100 & 100 \\
Egg yolk & 27 & 27 & 27 & 27 & 27 \\
Egg white & 54 & 54 & 54 & 54 & 54 \\
Milk & 50 & 50 & 50 & 50 & 50 \\
Sucrose & 100 & 0 & 0 & 0 & 0 \\
Polyols & 0 & 100 & 100 & 100 & 100 \\
Oil & 46 & 46 & 46 & 46 & 46 \\
Sodium bicarbonate & 4 & 4 & 4 & 4 & 4 \\
Citric acid & 3 & 3 & 3 & 3 & 3 \\
Salt & 1.5 & 1.5 & 1.5 & 1.5 & 1.5 \\
\hline
\end{tabular}

\subsection{Muffin preparation}

The batter was poured into a dosing machine (Edhard Corp., Hackettstown, USA). With the aid of a weighing scale, the quantity of batter dispensed was adjusted to exactly $45 \mathrm{~g}$ in each $60 \mathrm{~mm}$ diameter $\times 36 \mathrm{~mm}$ high paper mould. 12 molds were arranged in three rows of four muffins on a baking tray and baked for 16 minutes at $175{ }^{\circ} \mathrm{C}$ in an electric oven (Fagor Elegance $2 \mathrm{H}-114 \mathrm{~B}$, Guipúzcua, Spain) that had been preheated to this temperature for 10 
minutes. The oven, the tray and the tray position in the oven were identical in each case.

The muffins were left to cool at room temperature for one hour. The twelve muffins baked on the same baking tray were packed in sets of six in two polypropylene bags $\left(\mathrm{O}_{2}\right.$ permeability at $23{ }^{\circ} \mathrm{C}=1650 \mathrm{~cm}^{3} / \mathrm{m}^{2}$ day; water vapour permeability at $38{ }^{\circ} \mathrm{C}$ and $90 \%$ humidity $=9 \mathrm{~g} / \mathrm{m}^{2}$ day; thickness $=65 \mu \mathrm{m}$ ) and stored at $20^{\circ} \mathrm{C}$ for one day until the determinations were conducted.

All the formulations were prepared at least in duplicate.

\subsection{Thermal properties}

Differential scanning calorimetric (DSC) measurements were performed with a Q2000 calorimeter (TA-Intruments Crawley, UK), equipped with a refrigerated cooling system (RCS 90). Prior to sample measurements, the calibration for enthalpy and temperature was completed using indium ( $T_{\text {onset }}=155.74{ }^{\circ} \mathrm{C}$ and $\Delta \mathrm{H}=28.69 \mathrm{~J} / \mathrm{g}$ ). The measurements were performed in the batters as they were (water content from $30.45 \%$ to $31.21 \%$ ), in sweeteners powders as they were and in the models systems (flour-sweeteners 1:1 (w:w) using excess water (1:3 (w:w)). Distilled water was not used in the batter and sweeteners powder measurements. High volume DSC pans (100 $\mu \mathrm{L})$ (TAIntruments) were used in batter and model systems measurements and hermetic aluminium Tzero pans and lids (TA-Intruments) were used in sweeteners powders measurement. The samples were heated from 25 to 200 ${ }^{\circ} \mathrm{C}$ at $2{ }^{\circ} \mathrm{C} / \mathrm{min}$. and the cycle was repeated two times in order to provide a good resolution of the transition and phenomena. The period and the amplitude of modulation were $100 \mathrm{~s}$ and $0.5^{\circ} \mathrm{C}$ respectively at first cycle. An empty pan was used as the reference and dry nitrogen at a flow rate of $50 \mathrm{~mL} / \mathrm{min}$, was used as the purge gas. The enthalpy was expressed in $\mathrm{J} / \mathrm{g}$ of sample. Each formulation was measured twice. 


\subsection{Rheological properties}

The pasting properties were studied using a starch pasting cell (SPC) attached to a controlled stress rheometer (AR-G2, TA Instruments, Crawley, England).

\subsubsection{Starch Pasting Cell}

The effect of the sweeteners in starch gelatinization was studied in mixtures of flour-sweetener by using a starch pasting cell (SPC) attached to the reometer. The SPC consists of an impeller and a cylindrical cup $(3.6 \mathrm{~cm}$ wide and $6.4 \mathrm{~cm}$ high). The impeller is designed to fit closely into the cylindrical cup containing the sample. The top of the mixing element shaft is gradually extended to provide a non-contact, conically-shaped cover which significantly prevents solvent evaporation. Heating is accomplished through electrical elements placed concentrically to the cup and cooling through water recirculation in a helical conduit placed in close proximity to the outer walls of the cup. The cooling water flow is controlled through the cooling control unit, which is located upstream of the cup.

$25 \mathrm{~g}$ of water and $3 \mathrm{~g}$ of powdered ingredients $(3 \mathrm{~g}$ of flour in control system or 1,5 $\mathrm{g}$ of flour and 1,5 $\mathrm{g}$ of sweetener in flour-sweetener systems) were placed in the cylindrical cup of the SPC. The sample was first stirred strongly $\left(100 \mathrm{~s}^{-1}\right)$ for $10 \mathrm{~s}$ at $30^{\circ} \mathrm{C}$, then the shear rate was switched to $30 \mathrm{~s}^{-1}$ until the end of the test. The sample was heated from $30{ }^{\circ} \mathrm{C}$ to $90{ }^{\circ} \mathrm{C}$ at 15 ${ }^{\circ} \mathrm{C} / \mathrm{min}$ and the temperature was held at $90^{\circ} \mathrm{C}$ for $5 \mathrm{~min}$. The sample was then cooled to $30^{\circ} \mathrm{C}$ at $15{ }^{\circ} \mathrm{C} / \mathrm{min}$ and held at $30^{\circ} \mathrm{C}$ for $5 \mathrm{~min}$. The viscosity data were recorded over time; data were collected with the TA data analysis software provided by the instrument's manufacturer. The model systems samples were identified as flour system, flour-sucrose system (flour-Suc), flour-erythritol system (flour-Er), flour-isomalt system (flour-Iso), flour-maltitol system (flour-Mlt) and flour-sorbitol system (flour-Sor).

To objectively compare the behaviour of the different model systems the following parameters were taken from the viscogram curves: pasting 
temperature (PT), considered as the temperature at which viscosity begins to rise; peak viscosity (PV), considered as the highest viscosity achieved during heating; hot paste viscosity (HPV), considered as the viscosity value at the end of the isothermal period at $90^{\circ} \mathrm{C}$; and cold paste viscosity (CPV), considered as the viscosity value at the end of the isothermal period at $30^{\circ} \mathrm{C}$. In addition, the parameter relative breakdown was calculated as [(PV-HPV)/PV] and the parameter relative total setback was calculated as [(CPV-HPV)/CPV] (Arocas, Sanz \& Fiszman, 2009).

\subsubsection{Rheology of the muffin batters}

The batters were all kept at $25^{\circ} \mathrm{C}$ for 60 min after batter preparation before the rheological test. The samples were allowed to rest in the measurement cell for a $5 \mathrm{~min}$ equilibration time. A $40 \mathrm{~mm}$ diameter plate-plate sensor geometry with a serrated surface and a $1 \mathrm{~mm}$ gap was employed.

To simulate the effect of heating in the batter structure, temperature sweeps were performed from $25^{\circ} \mathrm{C}$ to $95^{\circ} \mathrm{C}$ at a heating rate of $1.0^{\circ} \mathrm{C} / \mathrm{min}$ and a strain amplitude of 0.0005 , which was well inside the linear viscoelastic region in all the temperature range and for all the samples, according to previous stress sweeps carried out at $25^{\circ} \mathrm{C}$ and $95^{\circ} \mathrm{C}$. Vaseline oil was applied to the exposed surfaces of the samples to prevent sample drying during testing. Additionally, mechanical spectra in the linear region from 10 to $0.01 \mathrm{~Hz}$ at $25^{\circ} \mathrm{C}$ were recorded in separate tests. The storage modulus (G') and the loss modulus (G") were recorded. Complex modulus $\left(\left|G^{*}\right|\right)$ was calculated as: $\left|G^{*}\right|=\left[\left(G^{\prime}\right)^{2}+\left(G^{\prime \prime}\right)^{2}\right]^{1 / 2}$.

Each formulation was measured twice.

\subsection{Specific gravity of batters}

The specific gravity of the batter (SG) was measured as the ratio of the weight of a standard container filled with batter (W2) to that of the same container filled with water (W1) (Eq. 1) (specific gravity =1 g/ml) as follows (Kissell \& Bean, 1978): 


$$
S G=W 2 / W 1
$$

Each formulation was measured twice.

\subsection{Physical properties of muffins}

\subsection{Height of the muffins}

Muffin height was measured with a calliper from the highest point of the muffin to the bottom of the paper mold after cooling for $1 \mathrm{~h}$ at room temperature. Each formulation was prepared twice, on different days, and 7 muffins from each batch (fourteen determinations) were measured.

\subsubsection{Instrumental texture of the muffins}

The instrumental texture measurements of the muffins were made with a TA.XT.plus Texture Analyser (Stable Microsystems, Godalming, UK) provided with Texture Exponent 32 software. Each formulation was prepared twice, on different days, and 4 muffins from each batch were measured (eight determinations for each formulation).

The muffins were cut horizontally at the height of the mold, the upper half was discarded and the $2.5 \mathrm{~cm}$ high lower halves were removed from the mold. A double compression test (Texture Profile Analysis (TPA)) was performed with a $75 \mathrm{~mm}$ diameter flat-ended cylindrical probe (P/75) and compression to $50 \%$ of the initial height, at a speed of $1 \mathrm{~mm} / \mathrm{s}$ with a $5 \mathrm{~s}$ waiting time between the two cycles. The parameters obtained from the curves were hardness (the peak force during the first compression cycle), springiness (the height that the food recovered between the end of the first compression and the start of the second compression), cohesiveness (the ratio of the positive force area during the second compression to the positive force area during the first compression) and chewiness (the product of hardness * cohesiveness * springiness), as well as resilience (area during the withdrawal of the first compression divided by the area of the first compression). 


\subsubsection{Sensory analysis}

Sensory analysis was carried out with 51 consumers aged between 18 and 62 who frequently consumed muffins. $31 \%$ of the consumers were male and $69 \%$ female. Each consumer tasted five muffins (Suc, Er, Iso , Mlt and Sor) presented monadically at a single session following a balanced complete block experimental design. The muffins were coded with random three digit numbers. The consumers scored their liking for the appearance, colour, texture, flavour, sweetness and their overall acceptance of each muffin sample on a nine-point hedonic scale ranking from 1 ("dislike extremely") to 9 ("like extremely").

\subsection{Statistical analysis of the results}

One way-ANOVA was applied to study the effect of sugar replacement on each of the instrumental parameters. Least significant differences were calculated using the Tukey test at a significance of $P<0.05$. These analyses were performed using SPSS for Windows Version 12 (SPSS Inc., Chicago, USA).

\section{Results and Discussion}

\subsection{Sweeteners thermal properties}

The thermal properties of Suc and the polyols (Sor, Er, Iso and Mlt) were studied by DSC. Melting is a first-order phase transition from the crystalline solid phase to the liquid phase, with no change in chemical composition (Lee, Thomas \&Schmidt, 2011a). The thermal parameters associated with the melting process (the onset temperature ( $\left.T_{\text {onset }}\right)$, peak temperature $\left(T_{\text {peak }}\right)$ and the enthalpy of melting $\left.(\Delta H)\right)$ were measured by heating the crystalline material at $2{ }^{\circ} \mathrm{C} / \mathrm{min}$ rate to a temperature where the melting endothermic peak was completed $\left(200{ }^{\circ} \mathrm{C}\right)$. The thermal parameters of the sweeteners powders are shown in Table 2. The melting peak temperature $\left(T_{\text {peak }}\right)$ of the different sweeteners varied from $96.90{ }^{\circ} \mathrm{C}$ for Sor powder to $184.81^{\circ} \mathrm{C}$ for Suc powder. Er powder peak temperature was $119.81^{\circ} \mathrm{C}$ and no 
differences were found between Mlt powder and Iso powder peak temperatures (148.64 ${ }^{\circ} \mathrm{C}$ and $144.31^{\circ} \mathrm{C}$, respectively). The behaviour of $\mathrm{T}_{\text {onset }}$ was similar to $T_{\text {peak. }}$. As occurred with $T_{\text {onset }}$ and $T_{\text {peak }}, \Delta H$ values were significantly different among the sweeteners. Iso powder had the lowest value of melting $\Delta \mathrm{H}$ followed by Suc powder and Er had the higher $\Delta \mathrm{H}$ values. No differences were found in $\Delta \mathrm{H}$ values among Mlt and Sor powders. Lee et al. (2011b) studied the loss of crystalline structure and thermal decomposition of sucrose and found that the number of endothermic peaks obtained by sucrose oscillate as a function of the sucrose sources (e.g., cane and beet sugar) and manufacturing methods (e.g., reagent grade versus commercial grade) (Lee et al., 2011b).

Table 2. Thermal properties (onset temperature ( $T_{\text {onset }}$ ), peak temperature $\left(T_{\text {peak }}\right)$ and enthalpy of melting $\left.(\Delta H)\right)$ of sweeteners powders.

\begin{tabular}{cccc}
\hline & \multicolumn{3}{c}{ Thermal properties } \\
\cline { 2 - 4 } & $\begin{array}{c}\text { Tonset } \\
\left({ }^{\circ} \mathrm{C}\right)\end{array}$ & $\begin{array}{c}\text { Tpeak } \\
\left({ }^{\circ} \mathrm{C}\right)\end{array}$ & $\begin{array}{c}\Delta \mathrm{H}(\mathrm{J} / \mathrm{g} \\
\text { of sweetener })\end{array}$ \\
\hline \multirow{2}{*}{ Sucrose } & $\begin{array}{c}177.78 \mathrm{e} \\
(1.15)\end{array}$ & $\begin{array}{c}184.81 \mathrm{~d} \\
(0.05)\end{array}$ & $\begin{array}{c}136.00 \mathrm{~b} \\
(5.37)\end{array}$ \\
\hline \multirow{2}{*}{ Erythritol } & $118.73 \mathrm{~b}$ & $\begin{array}{c}119.81 \mathrm{~b} \\
(0.21)\end{array}$ & $\begin{array}{c}438.40 \mathrm{~d} \\
(0.03)\end{array}$ \\
& $(4.53)$ \\
\hline \multirow{2}{*}{ Isomalt } & $136.09 \mathrm{c}$ & $144.31 \mathrm{c}$ & $\begin{array}{c}107.00 \mathrm{a} \\
\end{array}$ \\
& $(5.37)$ & $(3.48)$ & $(7.49)$ \\
\hline \multirow{2}{*}{ Maltitol } & $\begin{array}{c}146.32 \mathrm{~d} \\
\end{array}$ & $\begin{array}{c}148.64 \mathrm{c} \\
(0.85)\end{array}$ & $\begin{array}{c}167.90 \mathrm{c} \\
(0.83)\end{array}$ \\
\hline \multirow{2}{*}{ Sorbitol } & $92.32 \mathrm{a}$ & $96.90 \mathrm{a}$ & $157.10 \mathrm{c}$ \\
& $(1.24)$ & $(0.69)$ & $(1.70)$ \\
\hline
\end{tabular}

Values in parentheses are standard deviations. Means in the same column without a common letter differ $(P<0.05)$ according to the least significant difference multiple range test.

\subsection{Effect of the sweeteners in starch gelatinization. Flour-} sweetener systems

The effect was studied in binary systems composed of flour and the different sweeteners by DSC and rheology (starch pasting cell) techniques. 


\subsubsection{DCS measurements}

The results from DSC analysis showed an endothermic transition around $70^{\circ} \mathrm{C}$ in all samples, corresponding to the starch gelatinization process. The onset temperature ( $\left.T_{\text {onset }}\right)$, the peak temperature $\left(T_{\text {peak }}\right)$ and the enthalpy of the transition $(\Delta \mathrm{H})$ are shown in Table 3. All the sweeteners increased the $T_{\text {onset }}$ and $T_{\text {peak }}$ values being Mlt the one which showed the highest significant increase in both $T_{\text {onset }}$ and $T_{\text {peak }}$. Values of $T_{\text {onset }}$ and $T_{\text {peak }}$ were very similar among Suc and the polyols, being the Er system the one with the lowest value of $T_{\text {onset }}$ and $T_{\text {peak }}$, followed by Sor.

All the sweeteners decreased $\Delta \mathrm{H}$, althought no significant differences were found. Again Mlt showed the biggest effect. The enthalpy ranged from $4.05 \mathrm{~J} / \mathrm{g}$ (Flour-Mlt system) to $5.86 \mathrm{~J} / \mathrm{g}$ (flour system).

Table 3. Effect of the different sweeteners' in thermal properties associated to the starch gelatinization process. Tonset (onset temperature), $T_{\text {peak }}$ (peak temperature) and $\Delta H$ (enthalpy).

\begin{tabular}{cccc}
\hline \multirow{2}{*}{ Flour system } & $\begin{array}{c}32.04 \mathrm{a} \\
(2.33)\end{array}$ & $\begin{array}{c}68.07 \mathrm{a} \\
(0.24)\end{array}$ & $\begin{array}{c}5.86 \mathrm{a} \\
(0.06)\end{array}$ \\
\cline { 2 - 4 } & $\begin{array}{c}\mathrm{T}_{\text {onset }} \\
\left({ }^{\circ} \mathrm{C}\right)\end{array}$ & $\begin{array}{c}\mathrm{T}_{\text {peak }} \\
\left({ }^{\circ} \mathrm{C}\right)\end{array}$ & $\begin{array}{c}\Delta \mathrm{H}(\mathrm{J} / \mathrm{g} \\
\text { of flour }\end{array}$ \\
\hline \multirow{2}{*}{ Flour-Suc system } & $\begin{array}{c}6.55 \mathrm{ab} \\
(0.29)\end{array}$ & $\begin{array}{c}71.73 \mathrm{bc} \\
(0.06)\end{array}$ & $\begin{array}{c}4.94 \mathrm{a} \\
(0.49)\end{array}$ \\
\hline \multirow{2}{*}{ Flour-Er system } & $\begin{array}{c}63.68 \mathrm{ab} \\
(0.35)\end{array}$ & $\begin{array}{c}70.17 \mathrm{ab} \\
(0.66)\end{array}$ & $\begin{array}{c}5.19 \mathrm{a} \\
(0.34)\end{array}$ \\
\hline \multirow{2}{*}{ Flour-Iso system } & $\begin{array}{c}65.07 \mathrm{ab} \\
(0.81)\end{array}$ & $\begin{array}{c}72.66 \mathrm{bc} \\
(0.22)\end{array}$ & $\begin{array}{c}5.18 \mathrm{a} \\
(0.85)\end{array}$ \\
\hline \multirow{2}{*}{ Flour-Mlt system } & $\begin{array}{c}66.74 \mathrm{~b} \\
(1.02)\end{array}$ & $\begin{array}{c}73.04 \mathrm{c} \\
(1.57)\end{array}$ & $\begin{array}{c}4.05 \mathrm{a} \\
(0.47)\end{array}$ \\
\hline \multirow{2}{*}{ Flour-Sor system } & $\begin{array}{c}64.68 \mathrm{ab} \\
(0.22)\end{array}$ & $\begin{array}{c}71.46 \mathrm{bc} \\
(0.12)\end{array}$ & $\begin{array}{c}4.73 \mathrm{a} \\
(0.53)\end{array}$ \\
\hline
\end{tabular}

Values in parentheses are standard deviations. Means in the same column without a common letter differ $(\mathrm{P}<0.05)$ according to the least significant difference multiple range test

\subsubsection{Starch pasting cell (SPC)}

The viscosity values while mixing during heating and subsequent cooling were measured using a starch pasting cell attached to the rheometer 
(Figure 1). To compare the behaviour of the different systems objectively, the pasting temperature (PT), peak viscosity (PV), hot paste viscosity (HPV) and cold paste viscosity (CPV) values were taken from the viscograms, and the relative breakdown ((PV-HPV)/PV) and relative total setback ((CPV-HPV)/CPV) were calculated (Arocas, Sanz \& Fiszman, 2009).

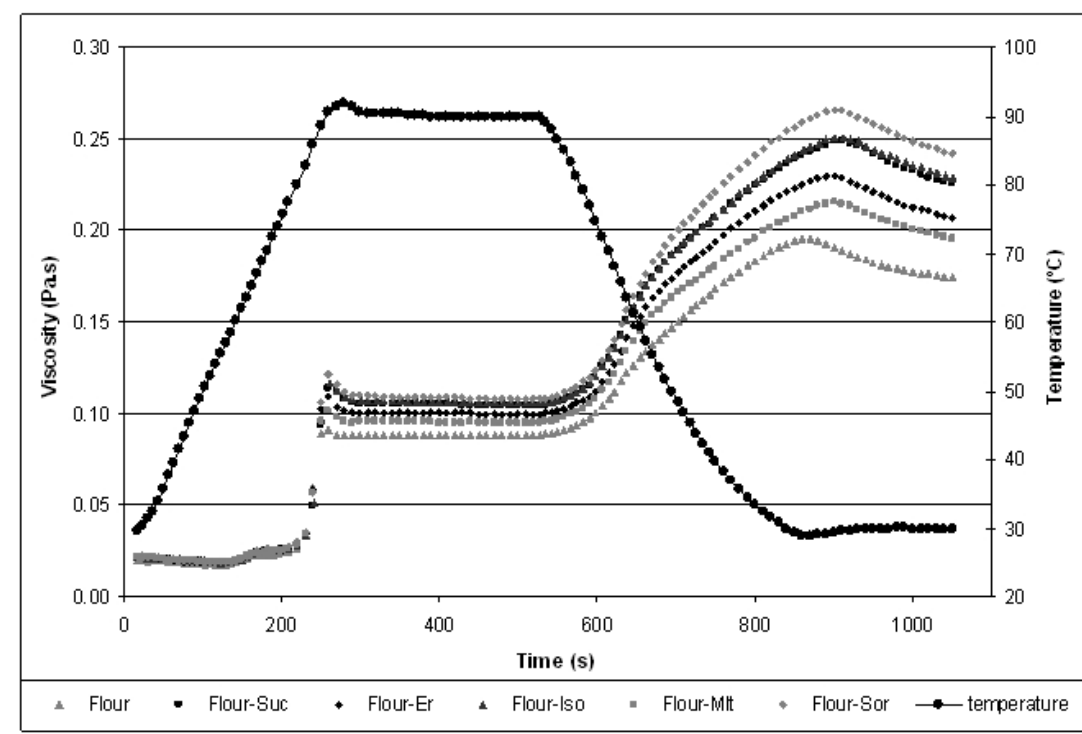

Figure 1. Viscosity-temperature profiles of model systems prepared with the different sweeteners.

The parameters are shown in Table 4. The PT indicates the temperature at which the increase in viscosity associated the starch gelatinization process takes place. Similarly to the thermal properties results, the presence of all the sweeteners increased significantly PT values. Sor, MIt and Iso showed the highest PT values (nearly to $62^{\circ} \mathrm{C}$ ). All the sweeteners also increased the PV values. The Flour system had the lowest PT and PV values, which were significantly different to the sweeteners' systems. The PV values ranged from 0.090 Pas for Flour system to 0.121 Pas for Flour-Sor system. In PV the Flour-MIt system was the closest to the Flour system, with lower values 
of PV than the other sweeteners. Relative breakdown is a parameter that provides information about the magnitude of the decrease in viscosity during heating, and in starch water systems it is very valuable to evaluate the degree of starch stability during heating and shearing. All the sweeteners increase the relative breakdown values indicating a highest decrease in the viscosity values during heating. The parameter relative total setback was also increased by all the sweeteners, especially by Sor. The parameter relative total setback provides information related to the increase in viscosity during the cooling process, which can be related to the extent of the starch retrogradation process.

The fact that sucrose increases the temperature of the starch gelatinization process is a well known phenomenon (Jang et al., 2001; Ikawa, 1998). The results obtained by DSC and the starch cell, indicate that all the polyols produced a similar effect than Suc on the starch gelatinisation. They delay the starch gelatinization temperature and decrease the enthalpy of gelatinization and produce an increase in the viscosity achieved during heating.

Table 4. Effect of the different sweeteners' in the pasting properties associated to the starch gelatinization process. PT (pasting temperature), PV (peak viscosity), HPV (hot paste viscosity) CPV (cold paste viscosity).

\begin{tabular}{ccccccc}
\hline & \multicolumn{6}{c}{ Pasting properties } \\
\cline { 2 - 7 } & $\begin{array}{c}\mathrm{PT} \\
\left({ }^{\circ} \mathrm{C}\right)\end{array}$ & $\begin{array}{c}\mathrm{PV} \\
(\mathrm{Pas})\end{array}$ & $\begin{array}{c}\text { HPV } \\
(\mathrm{Pas})\end{array}$ & $\begin{array}{c}\mathrm{CPV} \\
(\mathrm{Pas})\end{array}$ & $\begin{array}{c}\text { Relative } \\
\text { breakdown }\end{array}$ & $\begin{array}{c}\text { Relative } \\
\text { total } \\
\text { setback }\end{array}$ \\
\hline Flour system & $\begin{array}{c}58.65 \mathrm{a} \\
(0.21)\end{array}$ & $0.090 \mathrm{a}$ & $0.088 \mathrm{a}$ & $0.173 \mathrm{a}$ & $0.025 \mathrm{a}$ & $0.491 \mathrm{a}$ \\
& $(0.001)$ & $(0.001)$ & $(0.002)$ & $(0.005)$ & $(0.003)$ \\
\hline Flour-Suc & $60.25 \mathrm{~b}$ & $0.115 \mathrm{~cd}$ & $0.106 \mathrm{~cd}$ & $0.227 \mathrm{~cd}$ & $0.082 \mathrm{bc}$ & $0.534 \mathrm{c}$ \\
system & $(0.07)$ & $(0.001)$ & $(0.001)$ & $(0.001)$ & $(0.004)$ & $(0.003)$ \\
\hline Flour-Er & $60.50 \mathrm{~b}$ & $0.110 \mathrm{bc}$ & $0.101 \mathrm{bc}$ & $0.210 \mathrm{bc}$ & $0.083 \mathrm{bc}$ & $0.521 \mathrm{bc}$ \\
system & $(0.42)$ & $(0.001)$ & $(0.001)$ & $(0.004)$ & $(0.001)$ & $(0.004)$ \\
\hline Flour-Iso & $61.95 \mathrm{c}$ & $0.113 \mathrm{~cd}$ & $0.104 \mathrm{~cd}$ & $0.222 \mathrm{c}$ & $0.081 \mathrm{bc}$ & $0.534 \mathrm{c}$ \\
system & $(0.07)$ & $(0.005)$ & $(0.004)$ & $(0.010)$ & $(0.011)$ & $(0.006)$ \\
\hline Flour-MIt & $61.90 \mathrm{c}$ & $0.103 \mathrm{~b}$ & $0.096 \mathrm{~b}$ & $0.198 \mathrm{~b}$ & $0.064 \mathrm{~b}$ & $0.514 \mathrm{~b}$ \\
system & $(0.14)$ & $(0.001)$ & $(0.001)$ & $(0.003)$ & $(0.001)$ & $(0.000)$ \\
\hline Flour-Sor & $61.95 \mathrm{c}$ & $0.121 \mathrm{~d}$ & $0.108 \mathrm{~d}$ & $0.241 \mathrm{~d}$ & $0.105 \mathrm{c}$ & $0.551 \mathrm{~d}$ \\
system & $(0.07)$ & $(0.001)$ & $(0.000)$ & $(0.001)$ & $(0.010)$ & $(0.001)$ \\
\hline
\end{tabular}

Values in parentheses are standard deviations. Means in the same column without a common letter differ $(P<0.05)$ according to the least significant difference multiple range test 


\subsection{Muffin batters properties}

\subsubsection{Linear viscoelastic properties at $25^{\circ} \mathrm{C}$}

To determine the extension of the linear viscoelastic response stress sweets were carried out. Er and Iso batters had a higher linear viscoelastic region (up to $0.2 \mathrm{~Pa}$ ) than Suc, Sor and Mlt batters (up to $0.08 \mathrm{~Pa}$ ). These results indicate a higher resistance to the applied stress in Er and Iso batters than in the other batters.

The frequency dependence of the elastic modulus ( $\left.G^{\prime}\right)$ and the viscous modulus (G') in the linear region at $25^{\circ} \mathrm{C}$ is shown in Figure 2. In all the batter samples, the G' values were greater than the G" values. Both G' and G" showed a smooth frequency dependence, revealing a typical rheological behaviour of soft gels. Again, Er and Iso batters also showed a different behaviour with values of $G^{\prime}$ higher than the other batters in all the frequency range studied.

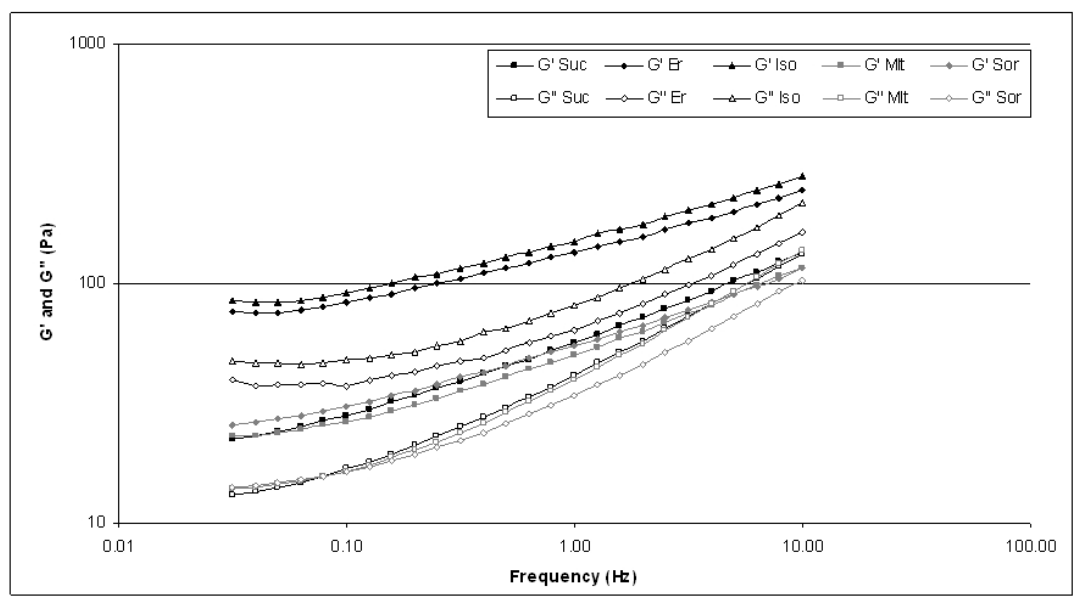

Figure 2. Effect of sweeteners on the evolution of G' and G" with frequency at $25^{\circ} \mathrm{C}$ in Spanish muffin batters. 


\subsubsection{Viscoelastic properties during heating}

To investigate the structural changes taking place in the different muffin batters during heating, viscoelastic properties were studied from $25^{\circ} \mathrm{C}$ to $95^{\circ} \mathrm{C}$, trying to simulate the batter's behaviour in the oven. The structural changes that occur in the muffin batter during baking are determining factors in bubble formation and stability and determine the final baked product structure and texture (Shelke, Faubion \& Hoseney, 1990). In particular, the role of sucrose is crucial during heating as it increases the starch gelatinization and protein denaturation temperatures. This allows the correct formation of water vapour and $\mathrm{CO}_{2}$ from the reaction of citric acid and sodium bicarbonate and allows the expansion of air cells sufficiently before the batter sets.

The effect of Suc and the polyols used as sucrose replacers in the complex modulus $\left|G^{*}\right|$ during heating of the different batters is presented in Figure 3. The initial $\left|\mathrm{G}^{*}\right|$ values (values at $25^{\circ} \mathrm{C}$ ) varied among the batters. The Suc free batter had the highest value $(513.90 \mathrm{~Pa})$. The addition of sweeteners produced a decrease of $\left|\mathrm{G}^{*}\right|$ (values ranged from $299.70 \mathrm{~Pa}$ in $\mathrm{Er}$ batter to 127.80 $\mathrm{Pa}$ in Suc batter). In all the batters, the initial increase in temperature produced a decrease in the values of the $\left|G^{*}\right|$. Initially this decrease may only be associated with the effect of increasing temperature, but up to a certain temperature (approximately $45^{\circ} \mathrm{C}$ ) it may be also associated with $\mathrm{CO}_{2}$ forming in the batter, diffusing into occluded air cells and expanding, resulting in a reduction in batter density (Ngo \& Taranto, 1986). Until the inflexion point, two different behaviours were observed in batters. In Suc free, Er and Iso batters, the $\left|\mathrm{G}^{*}\right|$ values decreased considerably from $35^{\circ} \mathrm{C}$ until the inflexion point, while in Sor, Mlt and Suc batters the $\left|G^{*}\right|$ values remained constant in this temperature range.

The increase in the values of $\left|G^{*}\right|$ after the inflexion point are related to the increase in the batter consistency associated to the starch gelatinization and protein coagulation processes. As expected, the presence of sucrose increases the starch gelatinization temperature and protein coagulation temperature. This behaviour was also described by other authors (Wootton \& Bamunuarachchi, 
1980; Eliasson, 1992; Abd Ghani et al., 1999). Similarly to sucrose, the different polyols also increased the inflexion point temperature. In the Suc free batter the inflexion point occurred at approximately $58^{\circ} \mathrm{C}$, while in the Suc batter this point increased to approximately $78^{\circ} \mathrm{C}$. In the polyols batters the inflexion points were between the Suc free batter and the Suc batter. In Er, Iso and Sor batters the increase in $\left|G^{*}\right|$ values occurred approximately at the same temperature (around $69^{\circ} \mathrm{C}$ ). The behaviour of the Mlt batter was the closest to Suc batter with an inflexion point around $75^{\circ} \mathrm{C}$. The delay in the temperature of the inflexion point in the presence of sucrose is crucial to avoid earlier thermosetting and give enough time for appropriate air and vapour expansion during baking. In this regard Mlt showed the most convenience effect.

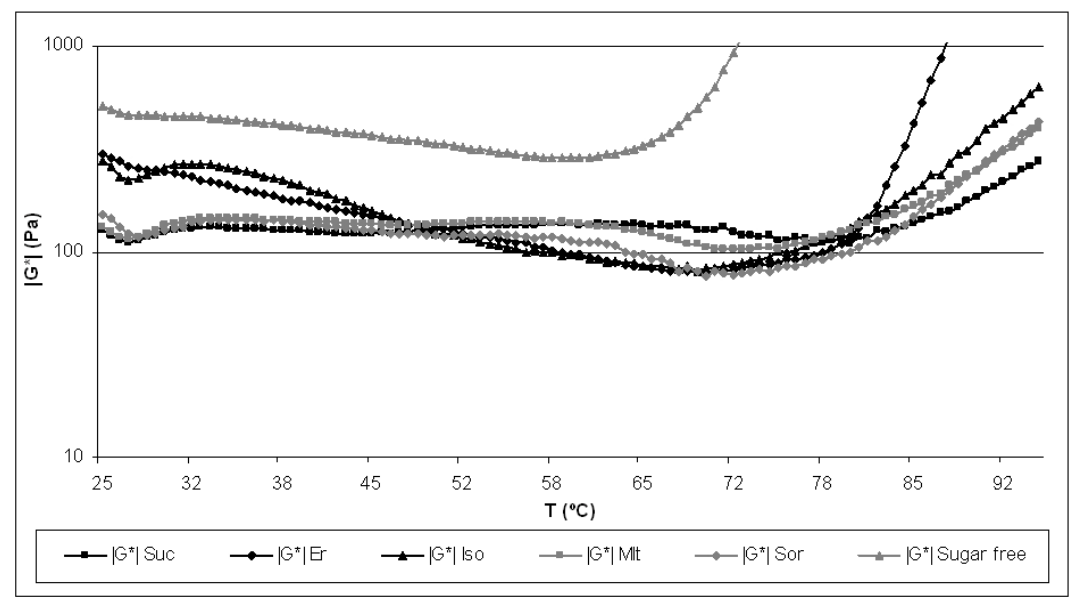

Figure 3. . Complex modulus $\left(\left|G^{*}\right|\right)$ as a function of increasing temperature in the Spanish muffin control batter and in batters with sucrose was replaced by different polyols.

\subsubsection{Thermal properties of muffin batters}

The results from DSC analysis in the batters showed the endothermic transition corresponding to the starch gelatinization at a temperature around 80$90{ }^{\circ} \mathrm{C}$. The reason for this increase in temperature in comparison with the Flour systems is related to the different water availability in both systems. In the Flour 
systems, the DSC measurements were carried out using excess water, while in the muffin batters, measurements were performed without extra water addition as the objective was to evaluate starch gelatinization in the presence of the water available in the system. The onset temperature ( $\left.T_{\text {onset }}\right)$ and peak temperature $\left(T_{\text {peak }}\right)$ and the enthalpy of the transition $(\Delta H)$ are shown in Table 5. No significant differences were found among Suc, and Mlt and Iso batters in $\mathrm{T}_{\text {onset }}$ and $\mathrm{T}_{\text {peak }}$. Similarly to the results found in the Flour systems, in Er and Sor batters the $T_{\text {onset }}$ and $T_{\text {peak }}$ values were significantly lower $(P=0.001)$ than all the other sweeteners. The effect of sweeteners on the enthalpy of starch gelatinization was not significant $(P=0.137)$ (Table 5$)$. This implies that no significant differences in the energy necessary for gelatinization of starch were found among the formulations. A similar effect of Sor and Mlt in the starch gelatinization properties studied by DSC was found by Psimouli and Oreopoulou (2012) in cake batters.

Table 5. Thermal properties (onset temperature ( $T_{\text {onset }}$ ), peak temperature $\left(T_{\text {peak }}\right)$ and enthalpy $\left.(\Delta H)\right)$ of starch gelatinization process in batters and specific gravity of batters with different sweeteners.

\begin{tabular}{ccccc}
\hline & \multicolumn{3}{c}{ Thermal properties } & \multirow{2}{*}{$\mathrm{SG}$} \\
\cline { 2 - 4 } & $\begin{array}{c}\mathrm{T}_{\text {onset }} \\
\left({ }^{\circ} \mathrm{C}\right)\end{array}$ & $\begin{array}{c}\mathrm{T}_{\text {peak }} \\
\left({ }^{\circ} \mathrm{C}\right)\end{array}$ & $\begin{array}{c}\Delta \mathrm{H} \\
(\mathrm{J} / \mathrm{g})\end{array}$ & $(\mathrm{g} / \mathrm{L})$ \\
\hline \multirow{2}{*}{ Suc } & $85.81 \mathrm{~cd}$ & $91.62 \mathrm{c}$ & $1.64 \mathrm{a}$ & $1.00 \mathrm{ab}$ \\
& $(0.36)$ & $(0.27)$ & $(0.19)$ & $(0.00)$ \\
\hline \multirow{2}{*}{ Er } & $73.37 \mathrm{a}$ & $79.73 \mathrm{a}$ & $1.52 \mathrm{a}$ & $1.04 \mathrm{~b}$ \\
& $(0.43)$ & $(0.48)$ & $(0.15)$ & $(0.01)$ \\
\hline \multirow{2}{*}{ Iso } & $86.87 \mathrm{~d}$ & $92.59 \mathrm{c}$ & $1.79 \mathrm{a}$ & $1.02 \mathrm{ab}$ \\
& $(0.30)$ & $(0.02)$ & $(0.11)$ & $(0.01)$ \\
\hline \multirow{2}{*}{ Mlt } & $85.12 \mathrm{c}$ & $91.45 \mathrm{c}$ & $2.09 \mathrm{a}$ & $0.99 \mathrm{ab}$ \\
& $(0.39)$ & $(0.42)$ & $(0.14)$ & $(0.01)$ \\
\hline \multirow{2}{*}{ Sor } & $79.45 \mathrm{~b}$ & $85.26 \mathrm{~b}$ & $1.82 \mathrm{a}$ & $0.96 \mathrm{a}$ \\
& $(0.16)$ & $(0.09)$ & $(0.26)$ & $(0.02)$ \\
\hline
\end{tabular}

Values in parentheses are standard deviations. Means in the same column without a common letter differ $(\mathrm{P}<0.05)$ according to the least significant difference multiple range test.

In summary, all the sweeteners (Suc and all the polyols) increase the starch gelatinization temperature, which is adequate for a correct thermosetting 
of muffin batters. However, differences among the different polyols were observed. The biggest difference was found for Er, which produced the lowest increase in the temperature of starch gelatinization in comparison to Suc and the other polyols. The rheological behaviour of the Er batter also showed the highest difference with the Suc batter. On the contrary the polyol Mit was the most similar to Suc, as stated by the calorimetric and rheological techniques.

\subsubsection{Muffin batter specific gravity}

Retention of air in batters is reflected by the specific gravity (SG) values. Lower specific gravity is associated with higher aeration of the batter (Khalil, 1998), indicating a higher capacity of the batter to incorporate air bubbles during beating and retain them (Bath, Shelke \& Hoseney1992). Martínez-Cervera et al. (2012) observed that sucrose reduction in muffins batters significantly increased the SG values, implying a reduction in the amount of air (less air incorporation or less capacity of the batter to retain air). Therefore, sucrose plays an important role in air incorporation during batter whipping. The effect on specific gravity of sucrose replacement by the different polyols is shown in Table 5. No significant differences were found among Suc and the different polyols $(P=0.021)$ in $S G$ values. Only a significant difference in air incorporation among Sor batter and Er batter was found, indicating that Sor batter produced higher air incorporation than the Er batter. In consequence, the different polyols have a similar functionality than sucrose in terms of air incorporation or air retention capacity.

\subsection{Spanish muffin properties}

The height of the muffins prepared with the different sweeteners is shown in Table 6. The Suc muffins showed the highest values of height. The lowest significant height was found in the Er muffin and no significant differences in height were found between Iso, Mlt and Sor muffins.

The elimination of sucrose causes an increase in hardness (MartínezCervera et al., 2012). The parameters obtained from the texture profile analysis 
are shown in Table 6. Er muffin showed hardness values significantly higher than Suc muffins and Sor and Mlt showed significantly lower hardness values than Suc muffins. No significant differences were found between Iso and Suc muffins. Similar behaviour was observed in chewiness values. Er had higher values in chewiness than Suc muffins and Iso, Mlt and Sor were lower in chewiness than Suc muffins. No differences were found among Suc and Mlt muffins formulations in springiness, but Er, Iso and Sor had significantly lower values than Suc muffins. All polyols had significantly lower values than Suc muffins in cohesiveness and resilience parameters. Psimouli and Oreopoulou (2012) studied the effect of sucrose replacement by different sweeteners in cakes. They found that no differences in texture parameters were found when sucrose was replaced by sorbitol and maltitol.

Table 5. Mean height and TPA values ( $\mathrm{H}$ : hardness; $\mathrm{S}$ : springiness; $\mathrm{Ch}$ : cohesiveness; Cw: chewiness; R: resilience) $(\mathrm{N}=8)$ of the muffins with different sweeteners.

\begin{tabular}{ccccccc}
\hline & Height & \multicolumn{5}{c}{ TPA } \\
\cline { 3 - 7 } & $(\mathrm{mm})$ & $\mathrm{H}(\mathrm{N})$ & $\mathrm{S}$ & $\mathrm{Ch}$ & $\mathrm{Cw}(\mathrm{N})$ & $\mathrm{R}$ \\
\hline \multirow{2}{*}{ Suc } & $48.15 \mathrm{a}$ & $29.02 \mathrm{~b}$ & $0.85 \mathrm{a}$ & $0.60 \mathrm{a}$ & $14.69 \mathrm{~b}$ & $0.24 \mathrm{a}$ \\
& $(2.14)$ & $(0.88)$ & $(0.01)$ & $(0.00)$ & $(0.52)$ & $(0.00)$ \\
\hline \multirow{2}{*}{$\mathrm{Er}$} & $38.88 \mathrm{c}$ & $104.65 \mathrm{a}$ & $0.78 \mathrm{~d}$ & $0.36 \mathrm{~d}$ & $28.87 \mathrm{a}$ & $0.13 \mathrm{e}$ \\
& $(3.12)$ & $(5.64)$ & $(0.01)$ & $(0.02)$ & $(1.85)$ & $(0.01)$ \\
\hline \multirow{2}{*}{ Iso } & $44.24 \mathrm{~b}$ & $26.83 \mathrm{bc}$ & $0.82 \mathrm{c}$ & $0.47 \mathrm{c}$ & $10.43 \mathrm{c}$ & $0.18 \mathrm{~d}$ \\
& $(1.27)$ & $(1.79)$ & $(0.01)$ & $(0.01)$ & $(0.78)$ & $(0.00)$ \\
\hline \multirow{2}{*}{ Mlt } & $44.93 \mathrm{~b}$ & $23.99 \mathrm{~cd}$ & $0.84 \mathrm{ab}$ & $0.53 \mathrm{~b}$ & $10.70 \mathrm{c}$ & $0.20 \mathrm{~b}$ \\
& $(1.53)$ & $(1.95)$ & $(0.01)$ & $(0.01)$ & $(0.99)$ & $(0.00)$ \\
\hline \multirow{2}{*}{ Sor } & $44.69 \mathrm{~b}$ & $20.37 \mathrm{~d}$ & $0.83 \mathrm{bc}$ & $0.47 \mathrm{c}$ & $7.92 \mathrm{~d}$ & $0.18 \mathrm{c}$ \\
& $(1.84)$ & $(2.90)$ & $(0.01)$ & $(0.01)$ & $(1.30)$ & $(0.01)$ \\
\hline
\end{tabular}

Values in parentheses are standard deviations. Means in the same column without a common letter differ $(\mathrm{P}<0.05)$ according to the least significant difference multiple range test.

In order to know the acceptability of the muffins formulations, a sensory analysis was carried out. The average results of the sensory evaluation of the muffins with different sweeteners are shown in Figure 4. Significant differences were found for all sensory attributes $(P=0.001)$. It was remarkable that muffins formulations with Suc, Sor and Mlt were evaluated in all sensory attributes up to 
5 points and in some attributes were evaluated up to 7 points. On other hand, Er was always evaluated below 5 points. For general acceptance, Suc, Sor and Mlt muffins scored values of 7.06 points, 6.25 points and 6.43 points, respectively, and no significant differences were found among them. Iso muffin was scored up to 4 points and Er was scored in 3 points. Also, for sweetness and flavour attributes, Suc, Sor and Mlt were significantly better scored than $\mathrm{Er}$ and Iso. In texture, colour and appearance all muffins formulations were scored over 5, except Er muffins which were scored below 3 in texture and below 2 in colour and appearance.

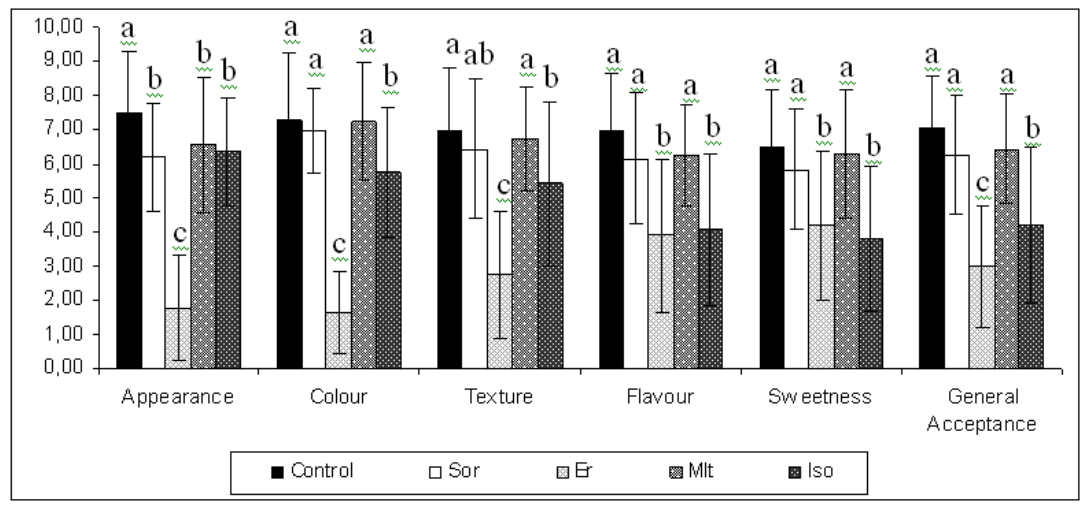

Figure 4. Sensory acceptability of control and the sucrose replaced by different polyols Spanish muffins.

\section{Conclusions}

The results from texture and consumer acceptability indicate that erythritol was the less suitable polyol to replace sucrose in muffins. These results can be related with the fact that erythritol also showed the highest differences with sucrose in terms of the effect in starch gelatinization and in the batter rheological properties before and during heating. On the other hand, maltitol, isomalt and sorbitol were found to be suitable as sucrose replacers in muffins. They have similar batter thermosetting properties than sucrose and the 
obtained muffins show good instrumental texture properties and sensory acceptability scores.

\section{References}

Abd Ghani MB, Che Man YB, Ali AB \& Mat Hashim DB (1999) Differential scanning calorimetry: gelatinisation of sago starch in the presence of sucrose and sodium chloride. Journal of the Science of Food and Agriculture 79, 2001-2009.

Akesowan A (2009) Quality of reduced-fat chiffon cakes prepared with erythritol-sucralose as replacement for sugar. Pakistan Journal of Nutrition 8 (9), 1383-1386.

Arocas A, Sanz T \& Fiszman SM (2009) Clean label starches as thickeners in white sauces. Shearing, heating and freeze/thaw stability. Food Hydrocolloids 23, 2031-2037.

Baeva MR, Terzieva VV \& Panchev IN (2003) Structural development of sucrose-sweetened and sucrose-free sponge cakes during baking. Nahrung/Food 47 (3), 154-160.

Bath DE, Shelke K \& Hoseney RC (1992) Fat replacers in high-ratio layer cakes. Cereal Foods World 37 (7), 495-496, 498-500.

Beesley PM (1995) Sugar functionality reviewed. Food Technology International Europe, 87-89.

Bornet FRJ (1994) Undigestible sugars in food products. The American Journal of Clinical Nutrition 59 (suppl), 763S-9S.

Eliasson AC (1992) A calorimetric investigation of the influence of sucrose on the gelatinization of starch. Carbohydrate Polymers 18 (2), 131-138.

Goossens J \& Roeper H (1994) Erythritol: a new sweetener. Food Science \& Technology Today 8 (3), 144-148.

Haji F (2009) Erythritol: a natural innovation. Agro Food Industry hi-tech 20 (3), 36-37. 
Ikawa Y (1998) Effects of sucrose replacement on baking process of sponge cakes. Journal of the Japanese Society for Food Science and Technology 45 (6), 357-363.

Jang JK, Lee SH, Cho SC \& Pyun YR (2001) Effect of Sucrose on Glass Transition, Gelatinization, and Retrogradation of Wheat Starch. Cereal Chemistry 78, 186-192.

Kamel BS \& Rasper VF (1988) Effects of emulsifiers, sorbitol, polydextrose and crystalline cellulose on the texture of reduced-calorie cakes. Journal of Texture Studies 19 (3), 307-320.

Kroger M, Meister K \& Kava R (2006) Low-calorie sweeteners and other sugar substitutes: A review of the safety issues. Comprehensive Reviews in Food Science and Food Safety 5 (2), 35-47.

Khalil AH (1998) The influence of carbohydrate-based fat replacers and with and without emulsifiers on the quality characteristics of low fat cake. Plant Foods for Human Nutrition 52, 299-313.

Kissell LT \& Bean MM (1978) AACC Technical Committee Report: Development of a method for angel food cake. Cereal Foods World 23 (3), 136-142.

Lee JK \& Oh MS (2010) Quality characteristics of sponge cakes with various sugar alcohols. Journal of the Korean Society of Food Culture 25 (5), 615-624.

Lee JW, Thomas LC \& Schmidt SJ (2011a) Investigation of the heating rate dependency associated with the loss of crystalline structure in sucrose, glucose and fructose using a thermal analysis approach (Part I). Journal of Agricultural and Food Chemistry 59, 684-701.

Lee JW, Thomas LC, Jerrell J, Feng H, Cadwallader KR \& Schmidt SJ (2011b) Investigation of Thermal Decomposition as the Kinetic Process That Causes the Loss of Crystalline Structure in Sucrose Using a Chemical Analysis Approach (Part II). Journal of Agricultural and Food Chemistry $59,702-712$. 
Lin SD, Hwang CF \& Yeh CH (2003) Physical and sensory characteristics of chiffon cake prepared with erythritol as replacement for sucrose. Journal of Food Science 68 (6), 2107-2110.

Martínez-Cervera S, de la Hera E, Sanz T, Gómez M \& Salvador A (2012) Effect of using erythritol as a sucrose replacer in making Spanish muffins incorporating xanthan gum. Food Bioprocess and Technology 5 (8), 3203-3216.

McNutt K \& Sentko A (1996) Sugar replacers. A growing group of sweeteners in the United States. Nutrition Today 31, 255-261.

Ngo WH \& Taranto MV (1986) Effect of sucrose level on the rheological properties of cake batters. Cereal Foods World 31 (4), 317-322.

Olinger PM \& Velasco VS (1996) Opportunities and advantages of sugar replacement. Cereal Foods World 41 (3), 110-113, 116-117.

Psimouli V \& Oreopoulou V (2012) The effect of alternative sweeteners on batter rheology and cake properties. Journal of the Science of Food and Agriculture 92 (1), 99-105.

Ronda F, Gómez M, Blanco CA \& Caballero PA (2005) Effects of polyols and nondigestible oligosaccharides on the quality of sugar-free sponge cakes. Food chemistry 90 (4), 549-555.

Shelke K, Faubion JM \& Hoseney RC (1990) The dynamics of cake baking as studied by a combination of viscometry and electrical resistance oven heating. Cereal Chemistry 67(6), 575-580.

Wootton M \& Bamunuarachchi A (1980) Application of differential scanning calorimetry to starch gelatinisation. III. Effect of sucrose and sodium chloride. Starch/Stärke 32, 126-129.

Zumbé A, Lee A \& Storey D (2001) Polyols in confectionery: the route to sugarfree, reduced sugar and reduced calorie confectionery. British Journal of Nutrition 85, Suppl. 1, S31-S45. 


\section{CAPÍtULO 4}

COCOA FIBRE AND ITS APPLICATION AS A FAT REPLACER IN CHOCOLATE MUFFINS

Martínez-Cervera S, Salvador A, Muguerza B, Moulay L \&

Fiszman SM

LWT - FoOd SCIENCE AND TECHNOLOGY (2011) 44, 729-736. 



\begin{abstract}
A study was made of the texture, composition, appearance, colour and descriptive sensory analysis of low-fat chocolate muffins in which part of the oil ingredient $(25 \%, 50 \%$ and $75 \%)$ had been replaced by soluble cocoa fibre and full-fat (no fat replacement) control sample to which cocoa powder had been added for comparison purposes.

The rheology of the batter was studied with a rheometer. The height of the baked product fell as the fat replacement percentage rose, but no weight loss differences were observed after $1 \mathrm{~h}$ cooling. The texture of the fatreplacement muffins showed lower values for hardness, chewiness and resilience than those of the control sample and retained greater moisture.

A panel of 10 trained assessors described the samples containing soluble cocoa fibre as being more cohesive and more difficult to chew and swallow as fat replacement rose and noted the appearance of a certain degree of stickiness and bitter notes of a slightly different nature to those of cocoa.
\end{abstract}

Keywords: muffins, soluble cocoa fibre, rheology, texture, descriptive sensory analysis. 


\section{Introduction}

In recent decades, the supply and consumption of sweet bakery products with a reduced energy content has been increasing in response to the demand for products with a lower calorie count (Sandrou \& Arvanitoyannis, 2000). The rise in cardiovascular disease and obesity and in other diet-related illnesses has led to consumers' taking a greater interest in the ingredients of food products and valuing those with a reduced caloric value more positively (Cheng et all. 2009). Moreover, because of the lifestyle and habits of the population, fibre consumption continues to be below the recommended rates. An effect of the lower consumption of fruit and vegetables, pulses and other plant products in recent decades is insufficient fibre intake (Miller-Jones, 2004). Dietary Reference Intakes recommend the consumption of $14 \mathrm{~g}$ of dietary fibre per $1000 \mathrm{kcal}$, or $25 \mathrm{~g}$ for adult women and $38 \mathrm{~g}$ for adult men, based on epidemiologic studies showing protection against cardiovascular disease (Slavin, 2008).

In the field of sweet bakery products, studies have been carried out to replace part of the fat with fibres, for example: peach fibre (Grigelmo-Miguel et all., 2001), inulin (Devereux et all., 2003), corn bran fibre (Jung et all., 2005), corn dextrins (Kim et all., 2001), guar gum or carboxymethyl cellulose (Kaur et all., 2000), potato pulp and pea flour (Kaack \& Pedersen, 2005) or $\beta$-glucan concentrates prepared from barley and oats (Kalinga \& Mishra, 2009), or soluble fibre from corn and oats (Warner \& Inglett, 1997).

In other studies, part of the flour has been replaced with different types of fibre, such as potato skin (Arora \& Camire, 1994), resistant starch (Baixauli et all., 2008a), oat bran, rice bran or barley fibre fractions (Hudson et all., 1992; Willis et all., 2009) or peach fibre (Grigelmo-Miguel et all., 1999), among others.

Dietary fibres produced and launched as innovative, healthy and multifunctional, are widely available; many of them are stated to have a white colour and a bland flavour. However, in a sustainable world, the interest in recovering by-products which may be used as an alternative source of fibre 
should not be ignored (Moulay et all., 2006a). Cocoa husks, a waste product from the chocolate industry, are an underutilized source of dietary fibre (McKee \& Latner, 2000). Cocoa husks are rich in insoluble dietary fibre as well as containing attractive quantities of antioxidant compounds (Lecumberri et all., 2007). When submitted to an enzymatic treatment, they yield a product that contains over $40 \%$ of soluble cocoa fibre. In particular, this fibre could add a cocoa colour and flavour to bakery products, making them more attractive than the conventional product while at the same time helping to reduce the fibre intake deficit. The fibre contains high quantities of branched pectic polysaccharides, which can be used to avoid the hypercholesterolemia associated with a high atherogenic index. As part of the diet, this fibre has led to a reduction in food intake and body weight, ascribed to a satiating effect (Moulay et all., 2006b). For this reason, it is considered of interest both for fat replacement (reducing the calorie content) and fibre enrichment in sweet bakery products and for the cocoa taste and colour it adds.

The aim of the present study is to assess the effects of a soluble cocoa fibre used as a fat replacer in chocolate muffins on a) the properties of the batter and $b$ ) the physical and sensory properties of the muffins.

\section{Materials and Methods}

\subsection{Cocoa muffin ingredients}

The chocolate muffin ingredients were wheat flour with a $10.47 \%$ moisture content measured by Method 44-40 (AACC International, 2000) (10.0\% protein content according to the supplier, Belenguer S.A., Valencia, Spain), sucrose (Azucarera Ebro, Madrid, Spain), pasteurized liquid egg white (Ovocity, Valencia, Spain), whole milk (Puleva, Granada, Spain), refined sunflower oil (Coosur S.A., Jaén, Spain), pasteurized liquid egg yolk (Ovocity, Valencia, Spain), sodium bicarbonate, citric acid (Martínez, Valencia, Spain), salt and soluble cocoa fibre (Naturex S.L, Valencia, Spain). The chemical composition of the cocoa fibre (in $\mathrm{g} / 100 \mathrm{~g}$ on an 'as is' basis) is $41.2 \%$ of 
soluble dietary fibre, a negligible fraction of insoluble dietary fibre $(<0.01)$ determined by the AOAC method 991.43 (AOAC, 1995), 17.92\% of proteins and $5.26 \%$ of fat (data provided by the supplier). The water retention capacity (WRC) and swelling power values were $5.15 \mathrm{~g} / \mathrm{g}$ and $5 \mathrm{~mL} / \mathrm{g}$ respectively).

The cocoa fibre gives the batter a cocoa colour, so powdered cocoa (cacao Toledo, Natra, Valencia, Spain, moisture $4.5 \mathrm{~g} / 100 \mathrm{~g}$ ) was added to the control sample alone for comparison purposes.

\subsection{Muffin preparation}

Four muffin formulations were prepared. One was used as the control (the only one with cocoa powder added) and the other three were prepared by replacing part of the oil with soluble cocoa fibre. The quantities of the ingredients that were present in all the formulations are shown in Table 1. The samples were identified as control, LFR (low fat replacement) (11.5 soluble cocoa fibre and 34.5 oil, g/ $100 \mathrm{~g}$ flour), MFR (medium fat replacement) (23.0 soluble cocoa fibre and 23.0 oil, g/ $100 \mathrm{~g}$ flour) and HFR (high fat replacement) (34.5 soluble cocoa fibre and $11.5 \mathrm{oil}, \mathrm{g} / 100 \mathrm{~g}$ flour). The batter was prepared in a mixer (Kenwood Major Classic, UK), in which the egg whites were whisked for 2 minutes at top speed. The sugar was added and mixed in for 30 seconds more at top speed. The egg yolk, half the milk and the citric acid were then added and the mixer was set to speed 3 for 1 minute. The flour, sodium bicarbonate and cocoa fibre (or cocoa powder, depending on the formulation) was added and the batter was beaten for an additional minute at speed 3 . Lastly, the mixer speed was increased to setting 4 , the rest of the milk was added and the oil was gradually dripped in. The batter was beaten for 3 minutes at speed 4 until smooth.

The batter was poured into a dosing machine (Edhard Corp., Hackettstown, USA). With the aid of a weighing scale, the quantity of batter dispensed was adjusted to exactly $45 \mathrm{~g}$ in each $60 \mathrm{~mm}$ diameter and $36 \mathrm{~mm}$ high paper mould. 12 moulds were arranged in three rows of four on a baking tray and baked for 17 minutes at $175^{\circ} \mathrm{C}$ in a conventional electric oven (Fagor 
Elegance 2H-114B, Guipúzcua, Spain) that had been preheated to this temperature for 10 minutes. The oven, the tray and the tray position in the oven were identical in each case.

Table 1. Formulation for control and low-fat replacement (LFR), mediumfat replacement (MFR), and high-fat replacement (HFR) muffins.

\begin{tabular}{lllll}
\hline Ingredients & Control & LFR & MFR & HFR \\
\hline Flour & 100 & 100 & 100 & 100 \\
Egg yolk & 27 & 27 & 27 & 27 \\
Egg white & 54 & 54 & 54 & 54 \\
Milk & 50 & 50 & 50 & 50 \\
Sugar & 100 & 100 & 100 & 100 \\
Cocoa & 10 & 10 & 10 & 10 \\
Oil & 46 & 34.5 & 23 & 11.5 \\
Cocoa fibre & 0 & 11.5 & 23 & 34.5 \\
Bicarbonate of soda & 4 & 4 & 4 & 4 \\
Citric acid & 3 & 3 & 3 & 3 \\
Salt & 1.5 & 1.5 & 1.5 & 1.5 \\
\hline
\end{tabular}

The muffins were left to cool at room temperature for one hour on a rack in order to avoid moisture condensing on their undersurface. The twelve muffins baked on the same baking tray were packed in sets of six in two polypropylene bags $\left(\mathrm{O}_{2}\right.$ permeability at $23^{\circ} \mathrm{C}=1650 \mathrm{~cm}^{3} / \mathrm{m}^{2}$.day; water vapour permeability at $38{ }^{\circ} \mathrm{C}$ and $90 \%$ humidity $=9 \mathrm{~g} / \mathrm{m}^{2}$.day; thickness $=65 \mu \mathrm{m}$ ) and stored at $20^{\circ} \mathrm{C}$ for 28 days. The measurements to study the effect of storage time were made at $0,7,14,21$ and 28 days from the baking date.

\subsection{Properties of the batter}

The specific gravity (SG) of the batter was measured as the ratio of the weight of a standard container filled with batter (W2) to that of the same container filled with water (W1) (specific gravity $=1 \mathrm{~g} / \mathrm{ml}$ ) as follows:

$$
S G=W 2 / W 1
$$


For the rheological determinations, special attention was paid to maintaining samples with the same thermomechanical history before testing. Accordingly, the batters were all kept at $25^{\circ} \mathrm{C}$ for 60 min after batter preparation before the rheological test. The flow properties of the muffin batters were studied using an AR G2 controlled-stress rheometer (TA Instruments, Crawley, UK) equipped with a Julaba F30-C thermostatic bath. The samples were allowed to rest in the measurement cell for a 25 min equilibration time. A 40-mm diameter plate-plate sensor geometry with a serrated surface and a 1-mm gap between the plates was employed, which was considered large enough with regard to the starch granule size (maximum size around $35 \mathrm{~mm}$ ). A continuous ramp was applied and apparent viscosity was measured as a function of shear rate over the $0.01-100 \mathrm{~s}^{-1}$ range for 5 minutes; 100 points with a logarithmic distribution at $25^{\circ} \mathrm{C}$ were recorded. Two replicates of each flow curve were run with samples prepared on different days, with good reproducibility since the differences between duplicates were less than $10 \%$. To protect against dehydration during long measurement times, vaseline oil (Panreac, Spain) was applied to the exposed surfaces of the all samples.

All curves were adjusted to the Ostwald model following the power-law equation (Ferguson \& Kembloski, 1991):

$$
\eta=K \dot{\gamma}^{n-1}
$$

where $\eta$ is the apparent viscosity, $K$ is the consistency index, $\dot{V}$ is the shear rate and $\mathrm{n}$ is the flow index.

\subsection{Muffin composition and appearance}

Each formulation was prepared twice (two replicates) on different days, and 4 muffins from each batch were used for each measurement (eight determinations).

The muffins were numbered by marking the underside of the mould and were weighed before (W3) and after baking and $1 \mathrm{~h}$ cooling (W4). The weight loss upon baking was calculated as follows: 


$$
\text { Weight loss }=(\text { W3-W4 })^{* 100 / W 3}
$$

Muffin height was measured with a caliper from the highest point of the muffin to the paper muffin cup bottom after $1 \mathrm{~h}$ cooling at room temperature.

The moisture content of the muffins was determined according to AACC Method 44-40 (AACC International, 2000).

The total dietary fibre of the muffins was analyzed according to AOAC Official Method 991.43 (AOAC, 1995).

A Konica Minolta CM-3500 spectrocolorimeter was used to measure the colour of the muffins. The results were expressed in accordance with the CIELAB system (D65 illuminant and $10^{\circ}$ viewing angle). The measurements were made with a $8 \mathrm{~mm}$ diameter diaphragm inset with optical glass. The parameters measured were $L^{*}\left(L^{*}=0\right.$ [black], $L^{*}=100$ [white]), $a^{*}\left(+a^{*}=\right.$ red $)$ and $b^{*}\left(+b^{*}=y e l l o w\right)$. The colour of the crust was measured at several points. The muffin was then cut in half on a plane parallel to its base and the colour of the crumb was measured at several points on the cut surface.

The total colour difference $\left(\Delta \mathrm{E}^{\star}\right)$ between the control sample and each of the muffins containing soluble cocoa fibre as a fat replacer was calculated as follows (Francis \& Clydesdale, 1975):

$$
\Delta \mathrm{E}^{*}=\left[\left(\Delta \mathrm{L}^{*}\right)^{2}+\left(\Delta \mathrm{L}^{*}\right)^{2}+\left(\Delta \mathrm{L}^{*}\right)^{2}\right]^{1 / 2}
$$

The values used to determine whether the total colour difference was visually obvious were the following (Bodart et all., 2008):

- $\Delta \mathrm{E}^{*}<1$ colour differences are not obvious for the human eye.

- $1<\Delta \mathrm{E}^{*}<3$ minor colour differences could be appreciated by the human eye depending of the hue.

- $\Delta \mathrm{E}^{*}>3$ colour differences are obvious for the human eye.

\subsection{Muffin texture}

The instrumental texture measurements were made with a TA.XT.plus Texture Analyser (Stable Microsystems, Godalming, UK). Each formulation was 
prepared twice, on different days, and 4 muffins from each batch (eight determinations) were measured for each of the storage times.

The muffins were cut horizontally at the height of the mould, the upper half was discarded and the $2.5 \mathrm{~cm}$ high lower halves were removed from the mould. A double compression test (Texture Profile Analysis) was performed to a height of $1.25 \mathrm{~cm}$ ( $50 \%$ compression) with a $75 \mathrm{~mm}$ diameter flat-ended cylindrical probe $(P / 75)$, at a speed of $1 \mathrm{~mm} / \mathrm{s}$ with a $5 \mathrm{~s}$ waiting time between the two cycles. The parameters obtained from the curves were hardness, springiness, cohesiveness, chewiness and resilience.

\subsection{Sensory Analysis}

\subsubsection{Panel training}

A panel of trained assessors $(\mathrm{N}=10)$ (6 women and 4 men, 25-55 years old) with experience in assessing bakery products was used for the descriptive sensory analysis. During the training sessions, the assessors suggested a list of meaningful sensory attributes for the product, especially those that distinguish the effect of the addition of soluble cocoa fibre, and discussed the definitions and how to evaluate each attribute. The panel reached a consensus and the following descriptors were chosen: height, chocolate colour, sponginess, springiness, stickiness, cohesiveness, difficulty in chewing and swallowing, bitter taste, chocolate taste and sweetness (Table 2).

Consistent results (as measured by a 2-way ANOVA with assessor and product as independent treatments) were obtained after seven 30 minute sessions. At the initial sessions, the control muffin and the muffin with the highest fat replacement were used to fix the ends of the rating scales. At the following training sessions, the subjects tasted 3 unlabelled samples (including the low- or medium-fat replacement muffin). A $10 \mathrm{~cm}$ unstructured scale was used throughout the training period. 
Table 2. List of descriptive terms and evaluation methods used in the descriptive sensory analysis of muffins by the trained panel.

\begin{tabular}{ll}
\hline Descriptors & Definition and assessment method \\
\hline $\begin{array}{l}\text { Appearance } \\
\text { Height } \\
\text { Chocolate colour } \\
\text { Sponginess }\end{array}$ & $\begin{array}{l}\text { Height of the whole muffin. } \\
\text { Strength of typical chocolate colour in the crumb. } \\
\text { Amount and size of gas cells, open structure. }\end{array}$ \\
$\begin{array}{l}\text { Manual texture } \\
\text { Springiness }\end{array}$ & $\begin{array}{l}\text { Speed of crumb shape recovery when pressure } \\
\text { from a finger is removed. }\end{array}$ \\
$\begin{array}{l}\text { Stickiness } \\
\text { Cohesiveness }\end{array}$ & $\begin{array}{l}\text { Stickiness of the crust when touched with a finger. } \\
\text { into a ball. }\end{array}$ \\
$\begin{array}{l}\text { Oral texture } \\
\text { Difficulty in chewing a piece of crumb can be rolled } \\
\text { swallowing }\end{array}$ & $\begin{array}{l}\text { Resistance to chewing and difficulty in forming the } \\
\text { bolus to swallow. }\end{array}$ \\
Flavour & \\
Bitter taste & Strength of bitterness different to that of cocoa. \\
Chocolate taste & Strength of typical chocolate taste. \\
Sweetness & Strength of sweet taste.
\end{tabular}

\subsubsection{Sample assessment}

The samples were assessed in a standardized tasting room equipped with individual booths (ISO, 1988). Data acquisition was performed using Compusense five releases 4.6 software (Compusense Inc., Guelph, Ont., Canada). An experimental design of balanced complete blocks was employed and the samples were rated in duplicate, at 2 separate sessions, on a $10 \mathrm{~cm}$ unstructured scale. The muffins were presented in a randomized order in their moulds on plastic trays, with randomly-assigned 3 digit codes, and each subject assessed 4 samples per session. Water was provided for rinsing the mouth between each sample.

\subsection{Statistical analysis of the results}

A one-way Anova of the instrumental parameters was performed to assess the effect of soluble cocoa fibre on the physical or sensory characteristics of the muffins. A two-factor (sample, time, and their interaction) analysis of variance of the sensory parameters was performed to determine 
differences among the samples due to different quantities of soluble cocoa fibre and storage times. Least significant differences were calculated by the Tukey test $(P<0.05)$. A principal components analysis of the descriptive sensory data was also conducted using the correlation matrix and linear regression was used to correlate instrumental and sensory data. SPSS 1.2 software was employed for the statistical analysis.

\section{Results and Discussion}

\subsection{Flow properties and specific gravity of the raw batter}

Batter viscosity is one of the important physical properties in cake baking; during baking, the velocity gradient in the batter as a whole will induce convection current at a given moment that depends on its viscosity, with low batter viscosity resulting in more convection flow (Frye \& Setser, 1991). Retention of air and leavening gases by batters is clearly reflected in the specific gravity values of the batters and is also a function of batter viscosity (Bath et all., 1992). The viscosity values, as a function of the shear rate for the control batter and the batters enriched with soluble cocoa fibre, showed that within the shear rate range studied the flow curves occur in the pseudoplastic zone; in other words, viscosity decreases with increased shear rate (data not shown). With the aim of characterizing the behaviour of the batters objectively, the experimental values were adjusted to the Ostwald-De Waale rheological model. This model is suitable for characterizing rheological behaviour in the pseudoplastic zone, i.e. for shear rate intervals which are neither very high nor very low, and presented good determination coefficients $\left(R^{2}>0.99\right)$.

The addition of fibre significantly increased the consistency value $(K)$ $(P=0.000)$ (Table 3). This increase in the $K$ value was also found by Masoodi et all. (2002) when apple pomace as a source of fibre was added in a batter cake, or by Kim et al. (2001) when corn dextrins were used as fat replacers in yellow layer cakes. Soluble cocoa fibre brought about a significant progressive lowering of the flow index $(n)(P=0.002)$, that is to say, the values were further 
removed from Newtonian behaviour $(n=1)$, indicating greater resistance to the flow and hence the existence of a more entangled structure. It should be noted that the amount of water in the formulation comes from the milk and eggs alone, as the formulation was not adapted because of the use of soluble cocoa fibre. This is an advantage, as other fibres, both soluble and insoluble, are high water absorbers and require changes in the formulation. The increasing viscosity of the raw batter as soluble cocoa fibre levels rose could be an unfavourable factor for the quality of the final baked product. Moreover, an excessive increase in viscosity could lead to problems in handling the batter, in mould filling (metering) and in cleaning the machinery, or to greater energy expenditure on pumping.

Table 3. Mean values $(\mathrm{N}=8)$ of flow and physical properties of muffin batter and muffins (LFR: low-fat replacement; MFR: medium-fat replacement; HFR: high-fat replacement).

\begin{tabular}{|c|c|c|c|c|c|}
\hline \multirow{3}{*}{ Sample } & \multirow{2}{*}{\multicolumn{2}{|c|}{$\begin{array}{l}\text { Batter } \\
\text { Flow parameters }\end{array}$}} & \multicolumn{3}{|l|}{ Muffins } \\
\hline & & & \multirow{2}{*}{$\begin{array}{l}\text { Specific } \\
\text { gravity } \\
\text { (g/L) }\end{array}$} & \multirow{2}{*}{$\begin{array}{l}\text { Height } \\
(\mathrm{mm})\end{array}$} & \multirow{2}{*}{$\begin{array}{l}\text { Moisture } \\
\text { content } \\
(\mathrm{g} / 100 \mathrm{~g})\end{array}$} \\
\hline & $\begin{array}{l}\text { K } \\
\text { (Pa.s) }\end{array}$ & $\mathbf{n}$ & & & \\
\hline Control & $\begin{array}{l}18.98 a \\
(0.33)\end{array}$ & $\begin{array}{l}0.55 a \\
(0.01)\end{array}$ & $\begin{array}{l}1.03 a \\
(0.01)\end{array}$ & $\begin{array}{l}46.4 a \\
(1.6)\end{array}$ & $\begin{array}{l}14.6 a \\
(0.7)\end{array}$ \\
\hline LFR & $\begin{array}{l}35.48 b \\
(0.08)\end{array}$ & $\begin{array}{l}0.45 b \\
(0.04)\end{array}$ & $\begin{array}{l}1.01 \mathrm{ab} \\
(0.02)\end{array}$ & $\begin{array}{l}46.6 a \\
(1.5)\end{array}$ & $\begin{array}{l}20.6 \mathrm{~b} \\
(0.4)\end{array}$ \\
\hline MFR & $\begin{array}{l}53.05 c \\
(0.91)\end{array}$ & $\begin{array}{l}0.41 b \\
(0.03)\end{array}$ & $\begin{array}{l}1.00 \mathrm{~b} \\
(0.01)\end{array}$ & $\begin{array}{l}45.2 a \\
(1.4)\end{array}$ & $\begin{array}{l}18.7 \mathrm{~b} \\
(0.4)\end{array}$ \\
\hline HFR & $\begin{array}{l}94.22 d \\
(0.83)\end{array}$ & $\begin{array}{l}0.30 c \\
(0.001)\end{array}$ & $\begin{array}{l}0.99 b \\
(0.15)\end{array}$ & $\begin{array}{l}42.0 \mathrm{~b} \\
(1.7)\end{array}$ & $\begin{array}{l}19.8 b \\
(0.6)\end{array}$ \\
\hline
\end{tabular}

Height and moisture were measured in freshly baked muffins (1 $\mathrm{h}$ after baking). The numbers in brackets are the standard deviations from the mean. Numbers with different letters within the same column are statistically different $(P<0.05)$ according to Tukey's test.

The specific gravity values of the samples with fat replaced by soluble cocoa fibre were slightly but significantly lower than those of the control $(P=0.010)$ (Table 3). Lower specific gravity is associated with better aeration of the batter (Kahlil, 1998), indicating a higher capacity of the batter to retain air bubbles during beating and, consequently, greater final volume and height in 
the baked product. In principle, a low specific gravity value could indicate a higher number of gas nuclei in the raw batter, which could encourage the formation of larger bubbles during baking and therefore result in greater height and volume. However, retention of air and leavening gases by batters during baking is also a function of batter viscosity (Bath et all., 1992). In fact, in the present study greater height and volume were not obtained in the samples with soluble cocoa fibre, as their high consistency values impeded volume development. Grigelmo-Miguel et al. (2001) found a similar result when peach dietary fibre was used as a fat replacer in muffins. A number of interrelated factors account for final volume in baking: the batter's rheological properties (affected by the ingredients), the level of air incorporation and the mixing and homogenization time and speed (Baik et all., 2000).

\subsection{Muffin composition and appearance}

Only with the $75 \%$ fat replacement $(34.5 \%$ cocoa fibre) were the muffins significantly smaller than the control samples $(P=0.000)$ (Table 3$)$. This loss in height reflects the imbalance that changing the formulation entails; some form of compensation should be studied, such as increasing the quantity of leavening agent or using a different leavening agent. Similar results were found when part of the oil in a muffin formulation was replaced by peach dietary fiber (GrigelmoMiguel et al., 2001); the height of the muffins remained the same as the control (without fibre) when the content in peach fibre was lower than $4 \mathrm{~g} / 100 \mathrm{~g}$ batter, while higher concentrations of peach fibre produced smaller muffins. Kim et al. (2001) found that the low specific gravity and relatively high viscosity of a cake batter prepared with maltodextrins as a fat replacer could have allowed more air to be incorporated, but that the low cake volume indicated that the membranes around the air cells were readily collapsed by gas expansion during baking.

In another study where part of flour was replaced by fibre, Baixauli et all. (2008b) also found a decrease in muffin height when increasing proportions of the flour were replaced by resistant starch; Grigelmo-Miguel et al. (1999) found similar results when peach fibre was used for flour replacement. 
Recently, Gómez et all. (2010) encountered less volume in layered cakes to which various fibres of different granulometries had been added for flour replacement. In general, the addition of any type of fibre to the ingredients of a bakery product causes a reduction in both the volume and the height of the final product (Peressini \& Sensidoni, 2009).

No significant differences $(P=0.513)$ in the values for weight loss upon baking (after $1 \mathrm{~h}$ cooling) were observed: the weight loss was close to $12 \%$ for all the formulations.

Twenty-four hours after baking, the moisture content values of the control sample were significantly lower than those for the formulations with soluble cocoa fibre $(P=0.000)$ (Table 3$)$. The greater moisture content can probably be linked to the water retention capacity of the soluble cocoa fibre; this could be a positive factor in sensory analysis if the soluble cocoa fibre caused the product to be perceived as moister, unlike other fibres which impart a dry mouthfeel. Increased moisture has also been reported by Grigelmo-Miguel et al. (2001) for muffins in which part of the fat had been replaced by peach fibre.

The dietary fibre content of the samples was 2.48, 2.48, 3.64 and 4.57 $\mathrm{g} / 100 \mathrm{~g}$ of fresh muffin for control, LFR, MFR and HFR respectively. As expected, the fibre content rose as the fat was increasingly replaced by soluble cocoa fibre. The control sample presented a similar value to that of the low fat replacement sample, which may be explained by the presence of powdered cocoa in the control. Indeed, an analysis of the quantity of soluble and insoluble fraction in the dietary fibre showed that all the fibre in the control sample was insoluble, whereas in all the other samples all of it was soluble. In accordance with European legislation, samples MFR and HFR can be considered "sources of fibre" because these products contains more than $3 \mathrm{~g}$ of fibre per $100 \mathrm{~g}$ of product.

\subsection{Colour of the muffins}

Adding soluble cocoa fibre $\left(L^{*}=45.75, a^{*}=11.98, b^{*}=26.36\right.$ for the pure ingredient) gave both the crust and the crumb a brown colour, demonstrating 
the absence of any bleaching effect. Since the muffins containing this fibre resembled chocolate muffins, some cocoa powder $\left(L^{*}=37.74, a^{*}=14.64\right.$, $\left.b^{*}=19.59\right)$ was added to the control samples for the purpose of comparison.

\subsubsection{Crust colour}

The lightest samples (highest $L^{*}$ values) were those in which $25 \%$ of the oil had been replaced by soluble cocoa fibre; the lightness values fell significantly $(P=0.032)$ as the soluble cocoa fibre concentration increased. The samples with the lowest fat replacement also had the highest values of $a^{*}$ (red component) $(P=0.001)$ and $b^{*}$ (yellow component) $(P=0.000)$, indicating a significantly brighter and more saturated brown-orange colour than in the muffins where greater proportions of fat had been replaced by soluble cocoa fibre (Table 4). In the control (the only sample containing powdered cocoa), the lightness, $a^{*}$ and $b^{*}$ values were not significantly different from those of the medium and high fat replacement sample, so soluble cocoa fibre was considered to give a good approximation to the colour that cocoa powder communicates to muffins. According to these results, the only sample where the $\Delta E^{*}$ was appreciable by the human eye $\left(\Delta E^{*}>3\right)$ was the low fat replacement formulation (Table 4).

\subsubsection{Crumb colour}

The variations in the crumb colour of the samples with soluble cocoa fibre as fat replacer were similar to the variations in crust colour. The lowest fat replacement muffin was the lightest (highest $L^{*}$ values) $(P=0.000)$ and the $b^{*}$ values showed that this sample had a brighter colour $(P=0.000)$ (Table 4). The crumb colour that the cocoa gave to the control sample was similar to that of the highest fat replacement samples; this would be in agreement with the $\Delta \mathrm{E}^{*}$ values, where only the high fat replacement formulation showed a colour difference that was not appreciable by the human eye $\left(\Delta \mathrm{E}^{*}<3\right)$ (Table 4$)$. Consequently, to match the chocolate muffin colour (in both crumb and crust), a minimum of $23 \mathrm{~g}$ of soluble cocoa fibre per $100 \mathrm{~g}$ of flour is advisable. 
Table 4. Mean colour values $(\mathrm{N}=8)$ for the crust and crumb of muffins prepared with increasing quantities of soluble cocoa fibre as a fat replacer (LFR: low-fat replacement; MFR: medium-fat replacement; HFR: high-fat replacement).

\begin{tabular}{|c|c|c|c|c|c|c|c|c|}
\hline \multirow{2}{*}{ Sample } & \multicolumn{4}{|l|}{ Crust } & \multicolumn{4}{|c|}{ Crumb } \\
\hline & $L^{*}$ & $a^{*}$ & $\mathbf{b}^{*}$ & $\Delta \mathrm{E}^{*}$ & $\mathbf{L}^{*}$ & $a^{*}$ & $\mathbf{b}^{*}$ & $\Delta \mathrm{E}^{*}$ \\
\hline Control & $\begin{array}{l}\text { 38.3ab } \\
(1.6)\end{array}$ & $\begin{array}{l}6.5 a \\
(0.4) \\
\end{array}$ & $\begin{array}{l}5.6 a \\
(0.6) \\
\end{array}$ & 0 & $\begin{array}{l}39.6 a \\
(0.5) \\
\end{array}$ & $\begin{array}{l}5.9 a \\
(0.3)\end{array}$ & $\begin{array}{l}6.0 a \\
(0.4) \\
\end{array}$ & 0 \\
\hline LFR & $\begin{array}{l}40.7 a \\
(2.2)\end{array}$ & $\begin{array}{l}8.5 b \\
(0.8)\end{array}$ & $\begin{array}{l}12.6 \mathrm{~b} \\
(1.7)\end{array}$ & 7.7 & $\begin{array}{l}47.6 \mathrm{~b} \\
(1.4)\end{array}$ & $\begin{array}{l}6.0 a \\
(0.1)\end{array}$ & $\begin{array}{l}12.2 \mathrm{~b} \\
(1.1)\end{array}$ & 10.1 \\
\hline MFR & $\begin{array}{l}36.0 \mathrm{~b} \\
(1.4)\end{array}$ & $\begin{array}{l}6.5 a \\
(0.7)\end{array}$ & $\begin{array}{l}7.53 a \\
(1.3)\end{array}$ & 3.0 & $\begin{array}{l}42.9 a \\
(2.8)\end{array}$ & $\begin{array}{l}6.2 a \\
(1.1)\end{array}$ & $\begin{array}{l}9.8 \mathrm{bc} \\
(2.6)\end{array}$ & 5.0 \\
\hline HFR & $\begin{array}{l}36.5 \mathrm{~b} \\
(2.8)\end{array}$ & $\begin{array}{l}6.1 \mathrm{a} \\
(0.7)\end{array}$ & $\begin{array}{l}6.7 a \\
(1.1)\end{array}$ & 2.1 & $\begin{array}{l}40.7 a \\
(0.5)\end{array}$ & $\begin{array}{l}5.7 a \\
(0.4)\end{array}$ & $\begin{array}{l}7.3 \mathrm{ac} \\
(0.4)\end{array}$ & 1.7 \\
\hline
\end{tabular}

Control formulation contains $10 \mathrm{~g} / 100 \mathrm{~g}$ flour of cocoa powder. The numbers in brackets are the standard deviations from the mean. Numbers with different letters within the same column are statistically different $(P<0.05)$ according to Tukey's test.

\subsection{Muffin texture}

The parameters obtained from the texture profile analysis (TPA) are shown in Table 5. The addition of soluble cocoa fibre as a fat replacer in muffins gave more tender and crumbly muffins with a more compact, less aerated crumb. All the soluble cocoa fibre samples had significantly lower hardness values than the control $(P=0.000)$ (Table 5). On comparing fat replacement levels, the hardness values increased as the fibre content rose but even the highest fat replacement sample was significantly less hard than the control. The greater softness of the soluble cocoa fibre samples would be positive if the samples were perceived as more tender. Similar results were found by Swanson et all. (2002), who obtained brownies with a lower hardness than in the control sample when shortening was replaced by polydextrose and lecithin.

The springiness value of the lowest fat replacement sample was not significantly different from that of the control; however, the springiness values 
fell significantly as soluble cocoa fibre was increasingly substituted for fat $(P=0.000)$, reflecting a more compact crumb.

Table 5. Mean texture parameter values $(\mathrm{N}=8)$ of fresh muffins prepared with increasing quantities of soluble cocoa fibre as a fat replacer (LFR: low-fat replacement; MFR: medium-fat replacement; HFR: high-fat replacement).

\begin{tabular}{llllll}
\hline Sample & Hard (N) & Spring & Cohes & Chew (N) & Resil \\
\hline \multirow{2}{*}{ Control } & $24.67 a$ & $0.86 a$ & $0.55 a$ & $11.37 a$ & $0.21 a$ \\
& $(1.53)$ & $(0.01)$ & $(0.01)$ & $(0.82)$ & $(0.01)$ \\
\hline \multirow{2}{*}{ LFR } & $17.59 \mathrm{c}$ & $0.87 \mathrm{a}$ & $0.49 \mathrm{~b}$ & $7.46 \mathrm{c}$ & $0.19 \mathrm{~b}$ \\
& $(0.96)$ & $(0.01)$ & $(0.01)$ & $(0.40)$ & $(0.01)$ \\
\hline \multirow{2}{*}{ MFR } & $17.67 \mathrm{c}$ & $0.83 \mathrm{a}$ & $0.46 \mathrm{c}$ & $6.75 \mathrm{c}$ & $0.16 \mathrm{c}$ \\
& $(1.07)$ & $(0.03)$ & $(0.01)$ & $(0.44)$ & $(0.01)$ \\
\hline \multirow{2}{*}{ HFR } & $21.91 \mathrm{~b}$ & $0.75 \mathrm{~b}$ & $0.49 \mathrm{~b}$ & $8.06 \mathrm{~b}$ & $0.16 \mathrm{c}$ \\
& $(1.36)$ & $(0.05)$ & $(0.01)$ & $(0.68)$ & $(0.00)$ \\
\hline
\end{tabular}

Hard: Hardness; Spring: Springiness; Cohes: Cohesiveness; Chew: Chewiness; Resil: Resilience. The numbers in brackets are the standard deviations from the mean. Numbers with different letters within the same column are statistically different $(P<0.05)$ according to Tukey's test.

The cohesiveness values were also significantly lower than in the control $(P=0.000)$, a factor that can be associated with the decreased hardness and would result in a greater crumbliness of the samples with lower fat levels. The contrary effect was observed when flour was replaced by fibre; in a study that replaced part of the flour with peach fibre, the resulting muffins were harder and chewier but the springiness and cohesiveness were similar when $31.7 \%$ of the flour was replaced with fibre (Grigelmo-Miguel et al., 1999); this change in muffin texture was related to greater batter density, lower formation of bubble nuclei and the inability to rise during baking. Baixauli et al., (2008a) obtained lower springiness and cohesiveness values than those of the control when resistant starch was substituted for flour.

Chewiness is a secondary texture parameter that is associated with difficulty in chewing the sample and forming a bolus before swallowing. The sequence was similar to that of hardness values: all the soluble cocoa fibre samples presented significantly lower chewiness values than the control 
$(P=0.000)$ (Table 5 ) but no significant differences were observed as a result of higher soluble cocoa fibre levels. These results could be related to the greater moisture retained by the soluble cocoa fibre samples, making them denser to chew.

Resilience reflects the greater or lesser symmetry of the first compression curve and is related to the degree to which the sample recovers when compression ceases; a resilience figure of 1 means that the sample behaves like a spring, returning immediately to its initial height. A dense structure containing little air will take longer to recover. In the present study, all the samples had low resilience values, which is typical of formulations containing sugar and fat, but the soluble cocoa fibre samples presented significantly lower resilience than the control $(P=0.000)$.

\subsection{Effect of storage time on texture}

To determine the effect of storage time on texture a texture profile analysis (TPA) was carried out. The hardness of all the samples increased significantly over the storage time (sample: $P=0.000$; time: $P=0.000$; sample $x$ time: $P=0.000$ ) (Figure 1). However, the hardness of the control tripled over the 28 days, indicating a higher staling rate, while lower values were attained by the soluble cocoa fibre samples over the same storage time. An analysis of the hardness values of the samples containing soluble cocoa fibre showed that the low fat replaced samples remained significantly softer than the control throughout the storage period; the hardness of the samples rose in line with the soluble cocoa fibre content and the high fat replacement samples were similar to the controls in this respect. However, while the hardness values of the control rose greatly towards the end of the storage period, those of the high fat replacement samples remained significantly lower. In general, the springiness of all the samples decreased significantly over the storage time (sample: $P=0.000$; time: $P=0.000$; sample $x$ time: $P=0.000$ ). Nonetheless, the variations were small and all the values fell within a fairly narrow range, with few significant differences between them (data not shown). 


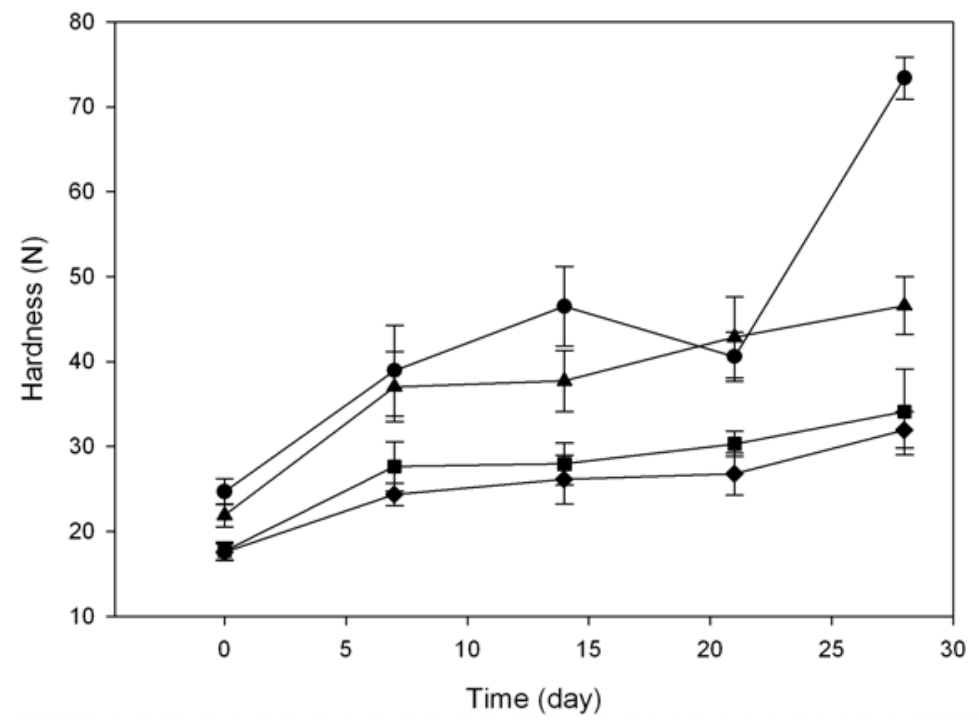

Figure 1. Evolution of hardness over storage time (• Control; replacement; $\mathbf{\square}$ Medium-fat replacement; $\Delta$ High-fat replacement).

The cohesiveness and resilience values of all the samples fell slightly but significantly over the storage time (sample: $P=0.000$; time: $P=0.000$; sample $x$ time: $P=0.000$ ) (data not shown). Lastly, the chewiness values of the soluble cocoa fibre samples presented no significant differences with storage time, whereas a significant rise, directly related to the increase in hardness, was observed in the controls (sample: $\mathrm{P}=0.000$; time: $\mathrm{P}=0.000$; sample $\mathrm{x}$ time: $\mathrm{P}=0.000$ ) (data not shown).

\subsection{Descriptive sensory analysis}

The trained panel suggested and assessed the following descriptors, some of which were distinctive of the effect of the soluble cocoa fibre: height, chocolate colour, sponginess, springiness, stickiness, cohesiveness, difficulty in chewing and swallowing, bitter taste, chocolate taste and sweetness.

All the attributes varied significantly with the addition of soluble cocoa fibre with the exception of sweetness, which was perceived as unchanged (data 
not shown); since all the samples were prepared with the same quantity of sugar, this result shows that the soluble cocoa fibre did not affect the perception of sweetness. The trained panel's scores for the different descriptors chosen for these samples are shown in Figure 2.

The control muffin was perceived as having a stronger chocolate colour than the muffins with soluble cocoa fibre. This was attributed to the soluble cocoa fibre giving a colour which is not identical to that of powdered cocoa. Among the soluble cocoa fibre samples, the colour was rated as being stronger as the soluble cocoa fibre content rose, but without reaching the same score as the control, a result that can be attributed to their tone being somewhat more orange than that of the control with cocoa, as ascertained by the instrumental colour measurement (Table 4).

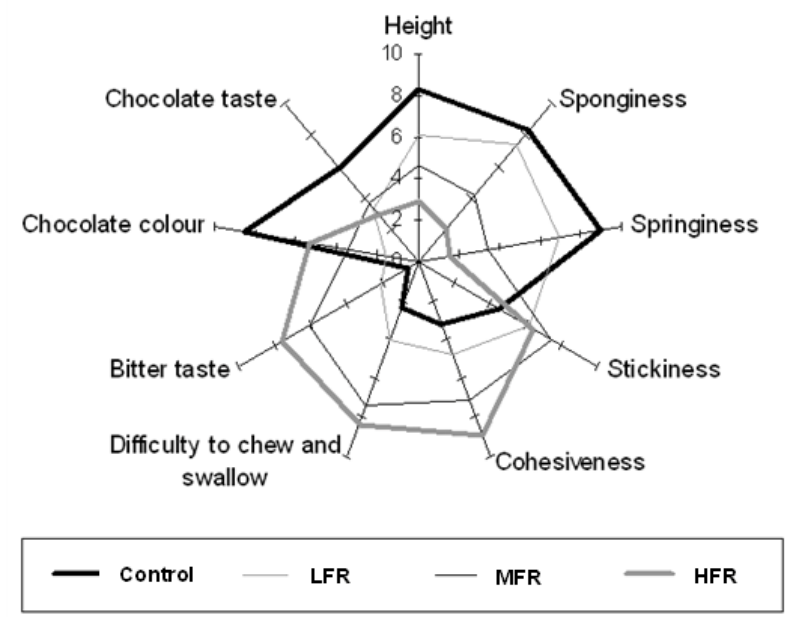

Figure 2. Mean scores for the descriptive sensory analysis by a trained panel $(\mathrm{N}=10)$.

The score for muffin height fell as the proportion of soluble cocoa fibre rose, which correlated lineally with the instrumental height measurements $\left(r^{2}=0.7395\right)$. The strength of the bitter taste increased with the soluble cocoa fibre content, as soluble cocoa fibre gives a different bitter taste to that of cocoa; the flavour imparted by the soluble cocoa fibre was distinguished from the 
chocolate taste, which was perceived more strongly in the control sample (which contained powdered cocoa). The incorporation of soluble cocoa fibre resulted in a chocolate-like taste with bitter notes different from those of cocoa. The surface stickiness of the crust ranged from imperceptible in the control sample to considerable in the samples with the highest soluble cocoa fibre content. This could be a negative quality factor. Both the sponginess of the crumb, perceived visually, and its springiness, perceived manually, fell as the soluble cocoa fibre content rose. A probable explanation is that the higher moisture content of the soluble cocoa fibre samples caused the crumb to stick together when compressed and fail to recover its initial shape with any speed, giving an impression of a denser, less airy crumb with a more closed type of structure. This structure also caused the perception of cohesiveness and difficulty in chewing and swallowing the samples to increase with higher percentages of fat replacement by soluble cocoa fibre, making them more difficult to chew and more cohesive and difficult to crumble. The cohesiveness and density (compactness) of brownies were also perceived as higher than those of the full fat control when Z-trim was added at levels of $50 \%, 75 \%$ and $100 \%$ fat replacement (Warner \& Inglett, 1997). These results contrast with those for instrumental chewiness (Table 5), which could reflect differences in the types of property that are detected by instrumental and sensory means (more related to hardness, crumbliness and tenderness in the former and to density and sticking while chewing and forming the bolus to swallow in the latter).

A Principal Component Analysis (PCA) was run on the sensory data (Figure 3). This extracted 2 components that explain $97.2 \%$ of the variation. The first component explains $82.5 \%$ and shows positive correlation with the attributes of height, springiness, sponginess and chocolate taste and negative correlation with cohesiveness, bitter taste, difficulty to chew and swallow and stickiness. The second component, which explains $14.7 \%$ of the variation, correlates positively with chocolate colour and chocolate taste and negatively with stickiness. Consequently, the sensory characteristics of all the samples are 
mainly explained by the positive side of PC1. The control sample possessed the greatest height, chocolate taste, springiness and sponginess; the low fat replacement sample showed a slight loss of these attributes but was mainly distanced from the control by its lack of chocolate colour. In the medium and high fat replacement samples, the predominant descriptors were bitter taste, cohesiveness, difficulty in chewing and swallowing and stickiness; the high fat replacement sample recovered a cocoa colour.

The addition of a small quantity of cocoa to the soluble cocoa fibre samples could probably even up the colour with the control.

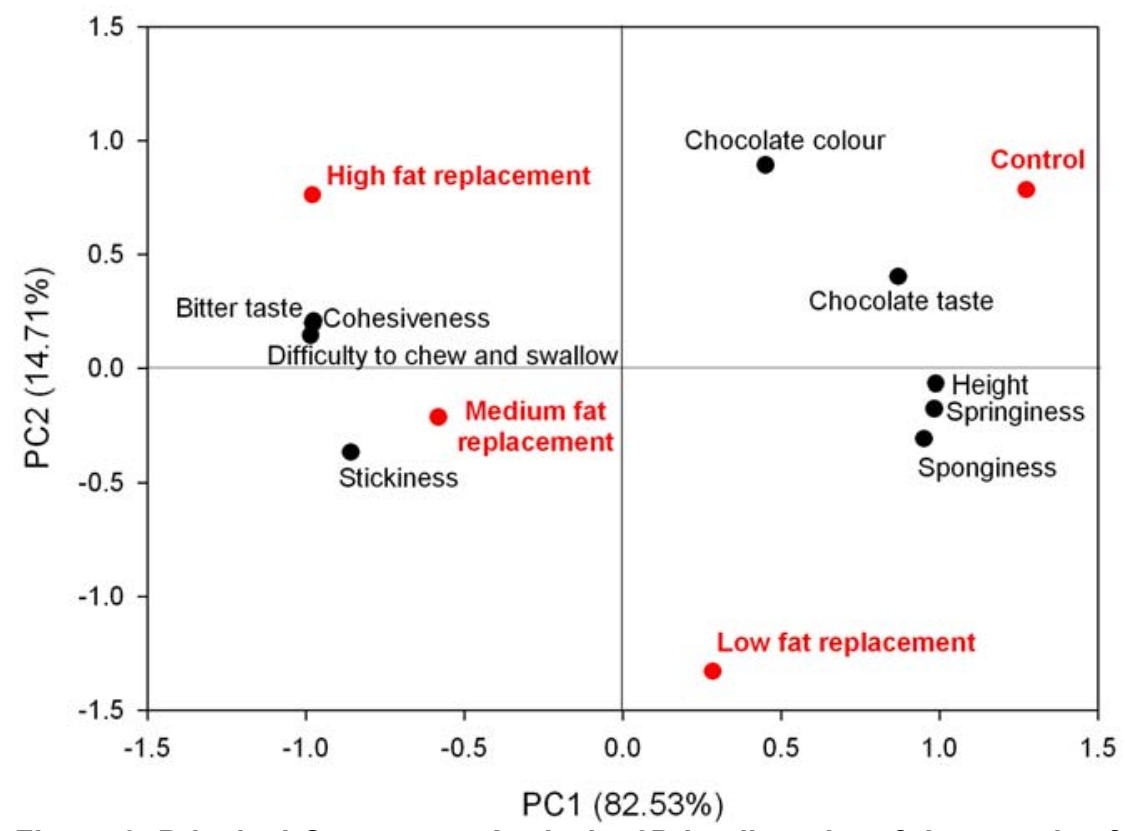

Figure 3. Principal Component Analysis. 2D-loading plot of the samples for the two principal components explaining $97.2 \%$ of the variance in the results. 


\section{Conclusions}

The results indicate that soluble cocoa fibre is an encouraging option for replacing oil in a chocolate muffin formulation. The main advantages were that adding soluble cocoa fibre gave muffins higher moisture and a more tender and crumbly texture, as they were more fragile than the control, and reduced the signs of hardening during storage. Also, adding soluble cocoa fibre gave a fair amount of colour. However, there are points that require improvement, such as the loss of height, perception of bitter taste and a certain surface stickiness. A study to attempt to correct the height by reformulating the leavening agent or beating the egg whites more before adding them to the batter and to correct the lack of a typical chocolate flavour and colour by adding a small quantity of cocoa to all the formulations would make it possible to conduct a wide-ranging consumer acceptance study with information on the very considerable fat reduction and high fibre content of the new products.

\section{References}

AACC International (2000) Method 44-40: Moisture (Modified Vacuum-Oven Method). En: Approved Methods of Analysis ( $10^{\text {th }}$ ed.). Editado por: AACC International, St. Paul, MN, U.S.A.

AOAC International (1995) Total, soluble and insoluble dietary fiber in foods. AOAC official method 991.43. En: Official Methods of Analysis (16 ${ }^{\text {th }}$ ed.). Editado por: AOAC International, Arlington, VA.

Arora A \& Camire ME (1994) Performance of potato peels in muffins and cookies. Food Research International 27, 15-22.

Baik OD, Marcotte M \& Castaigne F (2000) Cake baking in tunnel type multizone industrial ovens. Part II. Evaluation of quality parameters. Food Research Internacional 33, 599-607. 
Baixauli R, Salvador A \& Fiszman SM (2008a) Textural and colour changes during storage and sensory shelf life of muffins containing resistant starch. European Food Research and Technology 226, 523-530.

Baixauli R, Sanz T, Salvador A \& Fiszman SM (2008b) Muffins with resistant starch: Baking performance in relation to the rheological properties of the batter. Journal of Cereal Science 47, 502-509.

Bath DE, Shelke K \& Hoseney RC (1992) Fat replacers in high-ratio layer cakes. Cereal Food World 37, 495-500.

Bodart M, de Peñaranda R, Deneyer A \& Flamant G (2008) Photometry and colorimetry characterisation of materials in daylighting evaluation tools. Building and Environment 43, 2046-2058.

Cheng G, Karaolis-Danckert N, Libuda L, Bolzenius K, Remer T \& Buyken AE (2009) Relation of dietary glycemic index, glycemic load, and fiber and whole-grain intakes during puberty to the concurrent development of percent body fat and body mass index. American. Journal of Epidemiology 169, 667-677.

Devereux HM, Jones GP, McCormack L \& Hunter WC (2003) Consumer acceptability of low fat foods containing inulin and oligofructose. Journal of Food Science 68 (5), 1850-1854.

Ferguson J \& Kembloski Z (1991) Applied Fluid Rheology. Elsevier Science Publishers LTD. University Press, Cambridge.

Francis FJ \& Clydesdale FM (1975) Color differences. En: Food Colorimetry: Theory and Applications (pás. 143-151). Editado por: FJ Francis \& FM Clydesdale. The Avi publishing company, Inc (Westport, Connecticut).

Frye AM \& Setser CS (1991) Optimising texture of reduced-calorie yellow layer cakes. Cereal Chemistry 69 (3), 338-343.

Gómez M, Moraleja A, Oliete B, Ruiz E \& Caballero PA (2010) Effect of fibre size on the quality of fibre-enriched layer cakes. LWT - Food Science and Technology 43, 33-38. 
Grigelmo-Miguel N, Carreras-Boladeras E \& Martín-Belloso O (1999) Development of high-fruit-dietary-fibre muffins. European Food Research and Technology 210, 123-128.

Grigelmo-Miguel N, Carreras-Boladeras E \& Martin-Belloso O (2001) Influence of the addition of peach dietary fiber in composition, physical properties and acceptability of reduced-fat muffins. Food Science and Technology International 7 (5), 425-431.

Hudson CA, Chiu MM \& Knuckles BE (1992) Development and characteristics of high-fiber muffins with oat bran, rice bran, or barley fiber fractions. Cereal Foods World 37(5), 373-378.

ISO (1988) Sensory analysis: General guidance for design of test rooms. Standard $n^{\circ}$ 8589. Geneve, Switzerland.

Jung JY, Kim SA \& Chung HJ (2005) Quality characteristics of low-fat muffin containing corn bran fiber. Journal of the Korean Society of Food Science and Nutrition 34 (5), 694-699.

Kaack A \& Pedersen L (2005) Low energy chocolate cake with potato pulp and yellow pea hulls. European Food Research and Technology 221, 367-375.

Kahlil AH (1998) The influence of carbohdrate-based fat replacers and with and without emulsifiers on the quality characteristics of lowfat cake. Plant Foods for Human Nutritio 52, 299-311.

Kalinga D \& Mishra VK (2009) Rheological and physical properties of low fat cakes produced by addition of cereal $\beta$-glucan concentrates. Journal of Food Processing and Preservation 33, 384-400.

Kaur A, Singh G \& Kaur H (2000) Studies on development of low calorie baked using polydextrose as fat replacers. Advances in Food Sciences 28 (1), 713.

Kim HYL, Yeom HW, Lim HS \& Lim ST (2001) Replacement of shortening in yellow layer cakes by corn dextrins. Cereal Chemistry 78(3), 267-271.

Lecumberri E, Mateos R, Izquierdo-Piulido M, Rupérez P, Goya L \& Bravo L (2007) Dietary fibre composition, antioxidant capacity and physico-chemical 
properties of a fibre-rich product from cocoa (Theobroma cocoa L.). Food Chemistry 104, 948-954.

Masoodi FA, Bhawana S \& Chauhan GS (2002) Use of apple pomace as a source of dietary fiber in cakes. Plant Foods for Human Nutrition 57, 121 128.

McKee LH \& Latner TA (2000) Underutilized sources of dietary fiber: A review. Plant Foods for Human Nutrition 55, 285-304.

Miller-Jones J (2004) Dietary fibre intake, disease prevention, and health promotion: an overview with emphasis on evidence from epidemiology. En: Dietary fibre: Bio-active carbohydrates for food and feed. Editado por: JW van der Kamp, NG Asp, J Miller Jones \& G. Schaafsma. The Netherlands: Wageningen Academic Publishers.

Moulay L, Vilanova O, Ibarra A \& Muguerza B (2006a) An enzymatic process to obtain a soluble fiber product from cocoa shell. En: Proceedings Dietary Fiber Conference, 12-14 June, Helsinki, Finland, p. 28.

Moulay L, Ramos S, Granado-Serrano AB, Muguerza B, Bravo L \& Goya L (2006b) Colesterol lowering effect of a soluble cocoa fiber in hypercholesterolemic rats. En: Proceedings Dietary Fiber Conference, 1214 June, Helsinki, Finland, p. 39.

Peressini D \& Sensidoni A (2009) Effect of soluble dietary fibre addition on rheological and breadmaking properties of wheat doughs. Journal of Cereal Science 49 (2), 190-201.

Sandrou DK \& Arvanitoyannis IS (2000) Low-fat/calorie foods: current state and perspectives. Critical Reviews in Food Science and Nutrition 40 (5), 427447.

Slavin JL (2008) Position of the American Dietetic Association: health implications of dietary fiber. Journal of American Diet Association 108 (10), 1716-1731.

Swanson RB, Perry JM \& Carden LA (2002) Acceptability of reduced-fat brownies by school-aged children. Journal of the American Dietetic Association 102 (6), 856-859. 
Warner K \& Inglett GE (1997) Flavor and texture characteristics of foods containing Z-Trim corn and oat fibers as fat and flour replacers. Cereal Foods World 42 (10), 821-825.

Willis HJ, Eldridge AL, Beiseigel J, Thomas W \& Slavin JL (2009) Greater satiety response with resistant starch and corn bran in human subjects. Nutrition Research 29 (2), 100-105. 


\section{CAPÍtULO 5}

EFFECT OF NUTRIOSE ON RHEOLOGICAL, TEXTURAL AND SENSORIAL CHARACTERISTICS OF SPANISH MUFFINS

Martínez-Cervera S, de la Hera E, Sanz T, Gómez M \& Salvador $A$

FOOD AND BIOPROCESS TECHNOLOGY DOI 10.1007/s11947-012-0939-X 



\begin{abstract}
The effect of fat replacement by Nutriose on the physical properties of Spanish muffin batter and the baked muffins and on consumer acceptability was studied. In the muffin batter, replacement of fat by Nutriose increased the number of larger air bubbles, although the bubbles were not retained during baking. DSC analysis of the muffin batters revealed that the starch gelatinization temperature rose with increased fat replacement by Nutriose $\left(100 \%\right.$ fat replacement by Nutriose increase $\mathrm{T}_{0}$ values in $6{ }^{\circ} \mathrm{C}$, in comparison to the control) $(\mathrm{P} \leq 0.05)$. The presence of Nutriose decreased the height and volume of the muffins and significantly reduced their hardness and springiness $(P \leq 0.05)$. No significant differences between the control and the $50 \%$ fat replacement muffin were found in the consumer acceptability test $(P>0.05)$, indicating that Nutriose can be a suitable fat replacer up to the $50 \%$ level.
\end{abstract}

Keywords: fat replacer; nutriose; muffins; fibre; texture; rheology. 


\section{Introduction}

Magdalenas (Spanish muffins) are a special type of layer cake obtained by baking the batter in a paper mould. They are highly appreciated by consumers due to their good taste and spongy texture, but have a high calorie content due to the fat or oil in their composition. The increase in consumers' concern about the need to reduce calorie intake in the diet has prompted research on ways to reduce the calorie content of sweet bakery products, such as muffins. One of the strategies used for this purpose is to remove all or part of the fats (the component that provides the greatest number of calories) and replace them with other lower-calorie products (fat replacers).

Fat replacers are ingredients combining some of the functional properties of fats with less caloric content. Fat replacers can be based on carbohydrates, proteins, fats, or a combination of these. They are similar to fats in the properties they influence: viscosity, body, creaminess, and mouthfeel (Gómez, 2008).

The main problem with replacing the fat in cake-type products is the difficulty that other products have in providing the full functionality of fats (Shukla, 1995), which play a key role in the development of layer-cake-type products. On the one hand, fats help to incorporate air into the batter, which is essential for achieving an appropriate final volume and a spongy texture. Fats also help to create a more tender mouthfeel and moistness and increase the shelf-life of the final product by reducing the retrogradation phenomena (Gómez, 2008). Among the fat substitutes most often used in cakes and muffins, those based on carbohydrates stand out as having the best organoleptic properties (Bath et al., 1992). These substitutes include maltodextrins. The substitution of fat by maltodextrins affects the viscosity of the batter and the retention of air in the final cake, so total replacement is not recommended, and the final volume of the cakes can be improved with certain emulsifiers (Khalil, 1998; Lakshminarayan et al., 2006) or amilodextrins (Kim et al., 2001). Substituting fibre by-products for the fat in cakes has also been 
investigated and good results have been obtained with inulin and oligofructose (Devereux et al., 2003., Zahn et al., 2010), polydextrose (Frye and Setser , 1992), hydrocolloids (Kaur et al., 2000) and fibres derived from cereals (Warner \& Inglett, 1997, Lee et al. 2005; Kalinga and Mishra, 2009), from cocoa (Martínez-Cervera et al., 2011) and from peaches (Grigelmo-Miguel et al., 2001) although, in general, fat replacement by these products leads to lower organoleptic ratings.

Another carbohydrate based fat replacer is Nutriose, which is a resistant dextrin derived from wheat or maize starch. As other carbohydratebased fat substitutes, Nutriose absorbs water to form a gel-like matrix which confers some of the functional properties of fats.

Unlike standard dextrins, Nutriose is partially hydrolysed in the upper part of the digestive tract. Only $15 \%$ is enzymatically digested in the small intestine, while the rest passes to the colon, where $75 \%$ of the initial amount is slowly and progressively fermented in the large intestine and $10 \%$ is excreted (Van den Heuvel et al, 2004). Nutriose would reduce intestinal transit disorders and energy intake, and improve magnesium and calcium absorption and retention (Vermorel et al, 2004). Its intake has been proved to prevent colonic inflammation and reduce intestinal transit disorders (Rozan et al., 2009; Pouillart et al., 2010), and its effects on total cecal weight, cecal content, cecal wall weight, $\mathrm{pH}$, and short-chain fatty acid production could induce health benefits, since these effects are reported to be prebiotic (Guerin-Deremaux et al., 2010). In studies of overweight people it has also been shown that supplementing the diet with Nutriose reduces body weight, energy intake and hunger (Guerin-Deremaux et al., 2011) and lowers insulin resistance, as well as improving the determinants of metabolic syndrome (Li et al., 2010).

The aim of this work was to evaluate the ability of Nutriose to replace oil in Spanish muffins, in order to elaborate lower fat and calorie content products, more similar to the original and with the lowest loss of organoleptic acceptance. 


\section{Materials and methods}

\subsection{Batter preparation}

Five muffin formulations (Table 1) were prepared by replacing part or all of the fat with Nutriose (Nts). The Spanish muffin ingredients were wheat flour (10.9\% moisture; $8.98 \%$ protein, supplied by Harinera Castellana S.A. Medina del Campo, Spain), pasteurized whole egg (Ovopack, Marchena, Spain), refined sunflower oil (Koipesol, Madrid, Spain), whole UHT milk (Carrefour, Madrid, Spain), sucrose (Acor, Valladolid, Spain), Nutriose FM06 (dextrin) (monosaccharides $0.1 \%$, disaccharides $0.1 \%$, fibre index AOAC $88 \% /$ dry basis)) (Roquette, Lestrem, France), sodium bicarbonate (Martínez, Cheste, Spain), citric acid (Martínez, Cheste, Spain) and salt. The samples were identified as control, 25\%FR, 50\%FR, 75\%FR and 100\%FR (Table 1).

The batter was prepared in a professional mixer (KPM5, Kitchen Aid, St. Joseph, Michigan, USA), in which the egg was whisked for 2 minutes at speed of $580 \mathrm{rpm}$. The sucrose was added and mixed in for 30 seconds at the same speed. Half the milk and the citric acid were then added and the mixer was set to speed of $260 \mathrm{rpm}$ for 1 minute. The flour, sodium bicarbonate, Nutriose and natural salt were added and the mixture was beaten for a further 1 minute at the same speed. Lastly, the mixer speed was increased to $320 \mathrm{rpm}$, the rest of the milk was added and the oil was gradually dripped in. The mixture was beaten for 3 minutes at speed of 320 rpm until it was smooth.

Table 1. Spanish muffin formulations.

\begin{tabular}{lccccc}
\hline $\begin{array}{c}\text { Ingredients } \\
\text { (g/100 g flour) }\end{array}$ & Control & $\mathbf{2 5 \% F R}$ & $\mathbf{5 0 \% F R}$ & $\mathbf{7 5 \% F R}$ & $\mathbf{1 0 0 \% F R}$ \\
\hline Flour & 100 & 100 & 100 & 100 & 100 \\
Egg & 81 & 81 & 81 & 81 & 81 \\
Milk & 50 & 50 & 50 & 50 & 50 \\
Sucrose & 100 & 100 & 100 & 100 & 100 \\
Oil & 46 & 34.5 & 23 & 11.5 & 0 \\
Nutriose FM06 & 0 & 11.5 & 23 & 34.5 & 46 \\
Sodium bicarbonate & 4 & 4 & 4 & 4 & 4 \\
Citric acid & 3 & 3 & 3 & 3 & 3 \\
Salt & 1.5 & 1.5 & 1.5 & 1.5 & 1.5 \\
\hline
\end{tabular}




\subsection{Muffin preparation}

With the aid of a weighing scale, exactly $45 \mathrm{~g}$ of batter was dosed into each paper mould ( $60 \mathrm{~mm}$ diameter $\times 36 \mathrm{~mm}$ high). 12 moulds were arranged in three rows of four muffins on a baking tray and baked for 25 minutes at $190^{\circ} \mathrm{C}$ in an ST-02 modular electric oven (Salva, San Sebastián, Spain) that had been preheated to this temperature for 1 hour.

The muffins were left to cool at room temperature for one hour. The twelve muffins baked on the same baking tray were packed in a polyethylene bag, hermetically sealed and stored at $20{ }^{\circ} \mathrm{C}$ for one day until the determinations were conducted. All the formulations were prepared in duplicate.

\subsection{Properties of the batter}

\subsubsection{Specific gravity}

The specific gravity of the batter (SG) was measured as the ratio of the weight of a standard container filled with batter (W2) to that of the same container filled with water (W1) (Eq. 1) (specific gravity =1 $\mathrm{g} / \mathrm{ml}$ ) as follows (Kissell \& Bean, 1978):

$$
S G=W 2 / W 1
$$

Each formulation was measured twice.

\subsubsection{Bubbles in the batter}

The batter samples were imaged using a DM750 light microscope (Leica Microsystems, Wetzlar, Germany) with a magnification of 40x. A linked EC3 video camera (Leica Microsystems, Wetzlar, Germany) provided images using LAS EZ software (Leica Microsystems, Wetzlar, Germany).

Eight replicates of each formula were photographed.

\subsubsection{Rheology}

The linear viscoelastic properties of the muffin batters were studied using an AR G2 controlled-stress rheometer (TA Instruments, Crawley, UK). The batters were all kept at $25^{\circ} \mathrm{C}$ for 60 min after batter preparation before the 
rheological test. The samples were allowed to rest in the measurement cell for a $25 \mathrm{~min}$ equilibration time. A $40 \mathrm{~mm}$ diameter plate-plate sensor geometry with a serrated surface and a $1 \mathrm{~mm}$ gap was employed. To simulate the effect of heating on the batter structure, temperature sweeps were performed from $25^{\circ} \mathrm{C}$ to $95{ }^{\circ} \mathrm{C}$ at a heating rate of $1.0^{\circ} \mathrm{C} / \mathrm{min}$, a strain amplitude of 0.0005 and a oscillation frequency of $1 \mathrm{~Hz}$. The strain applied was selected to guarantee the existence of a linear viscoelastic response according to previous stress sweeps carried out at $25^{\circ} \mathrm{C}$ and $95^{\circ} \mathrm{C}$. Vaseline oil was applied to the exposed surfaces of the samples to prevent their drying during testing. Additionally, mechanical spectra in the linear region (stress of $0.04 \mathrm{~Pa}$ for control and 50\% FR formulations and stress of $0.08 \mathrm{~Pa}$ for $100 \% \mathrm{FR}$ formulation) from 10 to $0.01 \mathrm{~Hz}$ at $25{ }^{\circ} \mathrm{C}$ were recorded in separate tests. The storage modulus ( $\left.G^{\prime}\right)$ and the loss modulus (G") were recorded.

Each formulation was measured twice.

\subsubsection{DSC}

Differential scanning calorimetric (DSC) measurements were performed with a Q2000 calorimeter (TA-Intruments Crawley, UK). High volume DSC pans $(100 \mu \mathrm{L})$ were employed. The measurements were performed in the batters as they were (water content from $30.45 \%$ to $31.21 \%$ ) and in the baked muffins using excess water. The baked muffins were ground with a grinder and the DSC pans were filled with the powdered baked muffin and distilled water at a ratio of $1: 3(w / w)$. No distilled water was used in the batter measurements. The samples were heated from 25 to $130{ }^{\circ} \mathrm{C}$ at $10^{\circ} \mathrm{C} / \mathrm{min}$. The enthalpy was expressed in $\mathrm{J} / \mathrm{g}$ of sample.

Each formulation was measured twice. 


\subsection{Properties of the muffins}

\subsubsection{Height}

The muffin height was measured with a calliper, from the highest point of the muffin to the bottom of the paper mould, after cooling for $1 \mathrm{~h}$ at room temperature.

Each formulation was prepared twice, on different days, and seven muffins from each batch were measured (fourteen determinations).

\subsubsection{Volume}

The muffin volume was determined using a laser sensor with the BVM-L 370 volume analyzer (TexVol Instruments, Viken, Sweden). This procedure involves an instrument that spins the sample round and has a sensor laser and software to calculate the volume of the whole muffins.

All the measurements were carried out on the day after baking and seven samples were measured from each batch of each recipe (totalling 14 determinations for each recipe).

\subsubsection{Instrumental texture}

The instrumental texture measurements of the muffins were made with a TA.XT2 Texture Analyzer (Stable Microsystems, Surrey, UK) provided with Texture Expert software.

Each formulation was prepared twice, on different days, and four muffins from each batch were measured (eight determinations for each formulation).

The muffins were cut horizontally at the height of the mould, the upper half was discarded and the 2,5 cm-high lower halves were removed from the mould. A double compression test (Texture Profile Analysis (TPA)) was performed with a $75 \mathrm{~mm}$ diameter flat-ended cylindrical probe (P/75), applying compression to $50 \%$ of the initial height at a speed of $1 \mathrm{~mm} / \mathrm{s}$ with a $5 \mathrm{~s}$ waiting time between the two cycles. Pre and post test speed of texture analyzer were $10 \mathrm{~mm} / \mathrm{s}$ and a calibration weight of $5 \mathrm{Kg}$ was used. The parameters obtained 
from the curves were hardness (the peak force during the first compression cycle), springiness (the height that the food recovered between the end of the first compression and the start of the second compression), cohesiveness (the ratio of the positive force area during the second compression to the positive force area during the first compression) and chewiness (hardness * cohesiveness * springiness), as well as resilience (area during the withdrawal of the first compression divided by the area of the first compression).

\subsubsection{Bubbles in the muffins}

The muffins were cut on a horizontal plane at a distance of $2,5 \mathrm{~cm}$ from the base and images of the freshly cut surface of the crumb were captured using a DSC-W300 super steady shot camera (Sony, UK).

\subsection{Sensory analysis}

Sensory analysis was carried out with 52 consumers aged between 21 and 67 who frequently consumed muffins. $23 \%$ of the consumers were male and $77 \%$ female. Each consumer tasted three muffins (control, $50 \% \mathrm{FR}$ and $75 \% \mathrm{FR}$ ), presented monadically at a single session following a balanced complete block experimental design. The muffins were coded with random three-digit numbers. The consumers scored their liking for the appearance, colour, texture, sweetness and flavour and their overall acceptance of each muffin sample on a nine-point hedonic scale ranking from 1 ("dislike extremely") to 9 ("like extremely").

\subsection{Statistical analysis of the results}

One way-ANOVA was applied to study the effect of oil replacement on each of the instrumental and sensory parameters. Least significant differences were calculated using the Tukey test at a significance of $P<0.05$. These analyses were performed using SPSS for Windows Version 12 (SPSS Inc., Chicago, USA). 


\section{Results and Discussion}

\subsection{Specific gravity (SG) and microstructure of the batter}

Retention of air in batters is reflected by the specific gravity values. The effect on specific gravity (SG) of fat replacement with Nutriose can be seen in Table 2. As the percentage of fat substitution increased, a significant decrease in specific gravity was observed, implying an increase in the amount of air in the batter. Lower specific gravity is associated with better aeration of the batter (Kahlil, 1998), indicating a higher capacity of the batter to retain air bubbles during beating.

Table 2. Specific gravity (SG) of Spanish muffin batters, and starch gelatinization enthalpy $(\Delta H)$, temperature onset (To) and peak temperature (Tp) of the control batter and of the formulas in which fat was replaced by Nutriose.

\begin{tabular}{|c|c|c|c|c|}
\hline & \multirow[b]{2}{*}{$\begin{array}{l}\text { SG } \\
(g / L)\end{array}$} & \multicolumn{3}{|c|}{ Starch gelatinization } \\
\hline & & $\begin{array}{c}\Delta \mathrm{H} \\
(\mathrm{J} / \mathrm{g})\end{array}$ & $\begin{array}{c}\mathrm{T}_{\mathrm{o}} \\
\left({ }^{\circ} \mathrm{C}\right)\end{array}$ & $\begin{array}{c}\mathrm{Tp} \\
\left({ }^{\circ} \mathrm{C}\right)\end{array}$ \\
\hline Control & $\begin{array}{l}0.95 a \\
(0.00) \\
\end{array}$ & $\begin{array}{l}1.23 a \\
(0.10)\end{array}$ & $\begin{array}{c}94.97 a \\
(0.45) \\
\end{array}$ & $\begin{array}{c}101.96 a \\
(0.37)\end{array}$ \\
\hline $25 \% \mathrm{FR}$ & $\begin{array}{l}0.93 b \\
(0.00)\end{array}$ & , & - & . \\
\hline $50 \%$ FR & $\begin{array}{l}0.90 c \\
(0.01)\end{array}$ & $\begin{array}{l}1.42 a \\
(0.06) \\
\end{array}$ & $\begin{array}{c}96.39 a \\
(0.36)\end{array}$ & $\begin{array}{c}103.79 a \\
(0.09)\end{array}$ \\
\hline $75 \% F R$ & $\begin{array}{l}0.86 d \\
(0.00)\end{array}$ & - & - & - \\
\hline $100 \% \mathrm{FR}$ & $\begin{array}{l}0.75 \mathrm{e} \\
(0.00)\end{array}$ & $\begin{array}{l}1.49 a \\
(0.02) \\
\end{array}$ & $\begin{array}{c}101.00 \mathrm{~b} \\
(0.28)\end{array}$ & $\begin{array}{c}109.67 b \\
(0.74)\end{array}$ \\
\hline
\end{tabular}

Values in parentheses are standard deviations. Means in the same column without a common letter differ $(\mathrm{P}<0.05)$ according to the least significant difference multiple range test.

In other studies, which used other fibres as fat replacers the contrary effect was found. Pong et al. (1991), Khalil (1998) and Lee et al. (2005) observed higher specific gravity when fat was replaced by carbohydrate-based ingredients or Oatrim. In another study, Martinez-Cervera et al. (2011) did not find much variation in specific gravity values when fat was replaced by cocoa fibre in chocolate Spanish muffins. It is well known that stabilization of bubbles 
is one of the roles of fat in cake systems (Bath et al., 1992; Brooker, 1993a; Brooker, 1993b).

The obtained SG values were in agreement with the light micrography images of the batters (Figure 1). A progressive increase in the number and size of air bubbles was found as the Nutriose level rose. The higher number of larger bubbles in the $100 \%$ Nutriose batter is worth noting, as it implies that Nutriose promotes the formation of higher bubble size in the batter. For a better understanding of this behaviour, DSC and rheology studies were carried out.

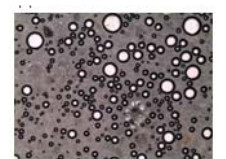

Control

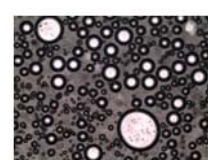

$25 \% \mathrm{FR}$

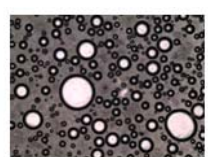

$50 \%$ FR

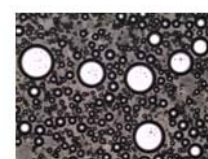

$75 \% \mathrm{FR}$

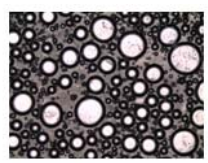

$100 \% \mathrm{FR}$

Figure 1. Light microscopy images of control and Nutriose fat replacement Spanish muffin batters.

\subsection{DSC results in the batter}

The results from DSC analysis showed an endothermic transition around $100{ }^{\circ} \mathrm{C}$ corresponding to the starch gelatinization process (Figure 2). The peak onset (To) and peak temperatures (Tp) and the enthalpy of the transition $(\Delta \mathrm{H})$ are shown in Table 2 . The To and Tp increased significantly with oil replacement by Nutriose $(\mathrm{P}=0.001)$. To increased $1.4^{\circ} \mathrm{C}$ and $6{ }^{\circ} \mathrm{C}$ and $\mathrm{Tp}$ increased $2{ }^{\circ} \mathrm{C}$ and $8{ }^{\circ} \mathrm{C}$ with $50 \%$ and $100 \%$ oil replacement by Nutriose, respectively, in comparison to the control. Since previous authors have reported that shortening does not affect the starch gelatinization temperature (Ghiasi et al. 1982; Shelke et all. 1990; Lin et al. 1994), the increase in the gelatinization temperature can be attributed solely to the presence of Nutriose due to a higher competition for water when nutriose concentration increase. A similar effect to that of Nutriose was encountered using other fibres as fat replacers. The employment of Oatrim (a carbohydrate-based fat substitute made from oats and composed primarily of $\beta$-glucan and amylodextrin) also increased the starch gelatinization temperature. Authors attributed this result to the effect of low 
molecular weight dextrins in reducing water activity, which would have a stabilizing effect on the amorphous regions of the starch granules (Lee et al.,2005).

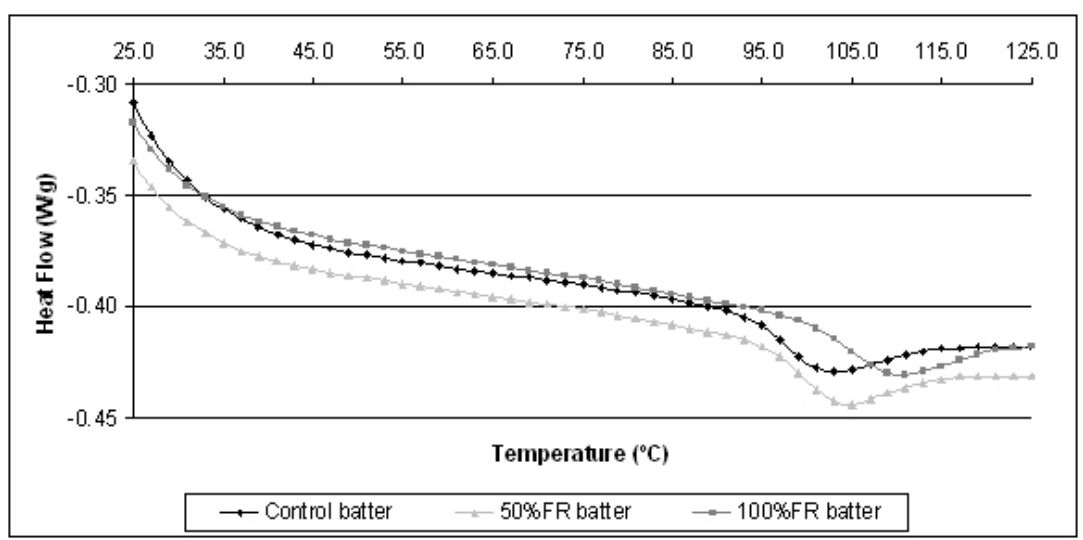

Figure 2. DSC thermograms of control and Nutriose fat replacement Spanish batters.

The effect of Nutriose on the enthalpy of starch gelatinization was not significant $(P=0.063)$. The enthalpy was $1.23 \mathrm{~J} / \mathrm{g}$ for the control formulation and $1.42 \mathrm{~J} / \mathrm{g}$ and $1.49 \mathrm{~J} / \mathrm{g}$ for $50 \% \mathrm{FR}$ and $100 \% \mathrm{FR}$, respectively. This implies that no differences in the energy necessary for gelatinization of starch were found among the formulations meaning that nutriose delayed starch gelatinization temperature but does not affect the enthalpy necessary for gelatinization of starch

\subsection{Viscoelastic properties.}

The frequency dependence of G' and G" in the linear region at $25^{\circ} \mathrm{C}$ is shown in Figure 3. In all the batter samples, the $G$ ' values were greater than the G" values in the frequency range studied. In addition, both G' and G" showed a smooth frequency dependence, revealing a typical rheological behaviour of soft gels. Besides, all the samples showed similar G' and G" values, indicating that the use of Nutriose as a fat replacer did not change the viscoelastic behaviour 
of the batter significantly at ambient temperature (the $\tan \delta\left(G^{\prime \prime} / G^{\prime}\right)$ values at 1 $\mathrm{Hz}$ for the control and the $100 \% \mathrm{FR}$ were 0.70 and 0.73 , respectively).

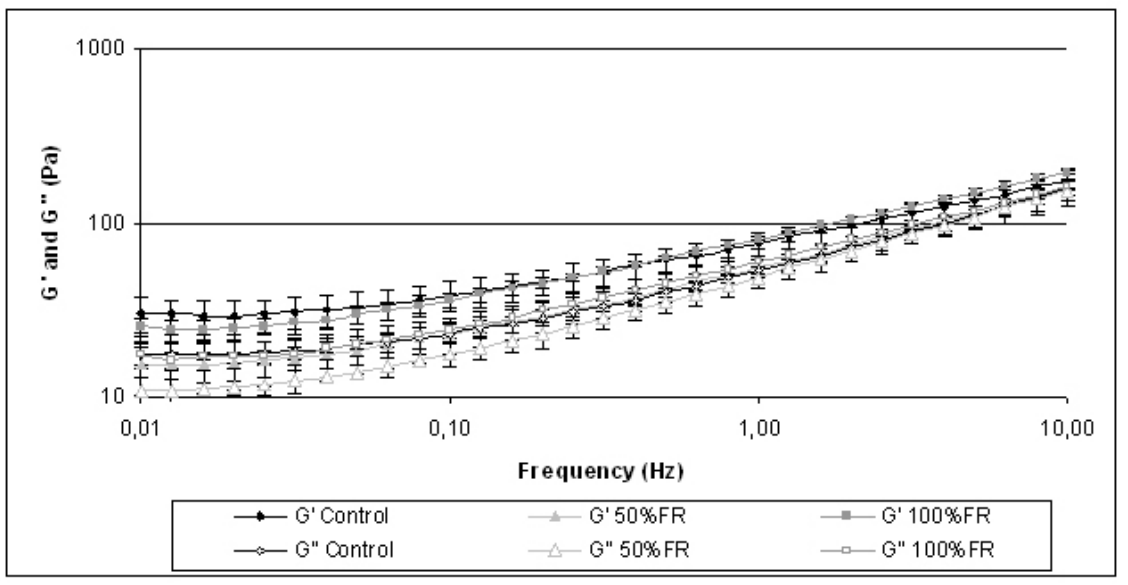

Figure 3. Effect of fat replacement with Nutriose on the evolution of G' and G" with frequency at $25^{\circ} \mathrm{C}$ in Spanish muffin batters.

To investigate the structural changes occurring in the different muffin batters during heating, the linear viscoelastic properties were studied from 25 ${ }^{\circ} \mathrm{C}$ to $95^{\circ} \mathrm{C}$ (the maximum temperature that the heating system could achieve), trying to simulate the batter's behaviour in the oven. The structural changes that occur in the muffin batter during baking are determining factors in bubble formation and stability and determine the final baked product structure and texture (Shelke et al., 1990).

The effect on the temperature profile of using Nutriose as a fat replacer can be seen in Figure 4, which showed the evolution of the G' and G" values during the heating of the different batters. As described in the frequency sweeps at $25^{\circ} \mathrm{C}$, the initial $\mathrm{G}^{\prime}$ and $\mathrm{G}$ " values $\left(T=25^{\circ} \mathrm{C}\right)$ were similar for all the samples (values of tan $\delta$ were 0.63 and 0.66 , for the control and $100 \% \mathrm{FR}$, respectively). Initially the G' and G" values remained almost constant with temperature in all the batters. In the control batter this stability continued until a temperature of approximately $65^{\circ} \mathrm{C}$ was reached. In the Nutriose batters, particularly the $100 \%$ fat replacement by Nutriose, the G' and G" values only remained stable up to 
approximately $35^{\circ} \mathrm{C}$ and then gently and gradually decreased as the temperature rose until it reached $60^{\circ} \mathrm{C}$. At a temperature of approximately 45 ${ }^{\circ} \mathrm{C}$, the decrease in $\mathrm{G}$ ' and G' values may be associated with $\mathrm{CO}_{2}$ formation in the batter: the gas formed, diffused into occluded air cells and expanded, resulting in a reduction in batter density (Ngo \& Taranto, 1986). This phenomenon occurred in 50\%FR but mainly in the $100 \% \mathrm{FR}$ batters, which as already commented had a lower specific gravity (higher air content) than the control batter.

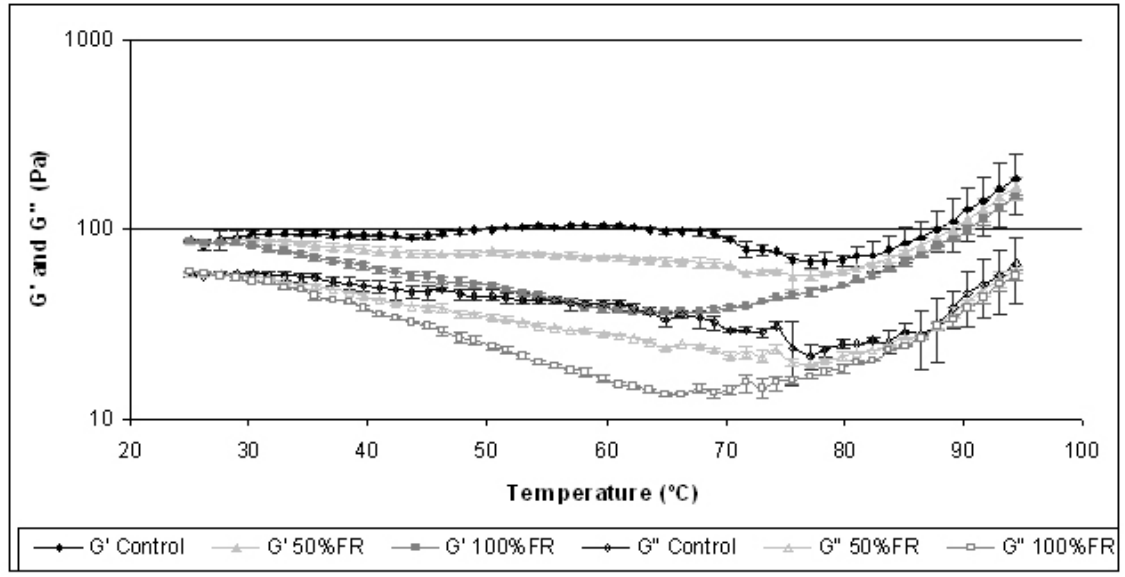

Figure 4. Effect of fat replacement with Nutriose on G' and G' as a function of increasing temperature in Spanish muffin batters.

In the Nutriose batters, the G' and G' values remained stable again from $60{ }^{\circ} \mathrm{C}$ (values of tand were 0.38 and 0.41 , for the control and $100 \% \mathrm{FR}$, respectively) to approximately $70^{\circ} \mathrm{C}$ (values of tan $\delta$ were 0.36 and 0.36 , for the control and $100 \% \mathrm{FR}$, respectively), then from $70{ }^{\circ} \mathrm{C}$ onwards they started to increase very gradually with the temperature. The G' and G" values obtained at the end of the temperature sweep were slightly higher in the control than in the batters with fat replacement by Nutriose. Bearing the DSC measurements of starch gelatinization onset temperatures in mind, the change in slope observed in the control curve at $86-87^{\circ} \mathrm{C}$ could be attributed to the onset of starch gelatinization. In the $100 \%$ Nutriose batter this last change in slope was not 
clearly observed, denoting that the starch gelatinization will occur at higher temperatures, which were not achieved by the reomether (maximum temperature $95^{\circ} \mathrm{C}$ ). As stated in the DSC results, it has been reported by other authors that shortenings don't affect the starch gelatinization temperature (Lee et al. 2005, Shelke et al. 1990; Lin et al. 1994), so the delay in the starch gelatinization process in the $100 \%$ fat replacement by Nutriose batter could be attributed merely to the presence of Nutriose.

\subsection{Bubbles in the crumb and muffin height and volume}

The height and volume values of the muffins with fat replacement by Nutriose are shown in Table 3 . The muffins with Nutriose differed significantly from the control muffin in height $(P=0.000)$ and volume $(P=0.000)$. The control formulation muffins exhibited greater height and volume. Fat replacement up to $50 \%$ produced a significant decrease in volume. In other studies that used other fibres as fat replacer also a significant decrease in cake volume was found when fat was replaced by Oatrim (Lee et al., 2005). Similarly, Zahn et al. (2010) observed a decrease in muffin height and volume when $50 \%$ of the fat was replaced by different types of inulin. Chung et al. (2010) studied the effect of replacing $40 \%$ of butter with waxy corn starch and they too obtained a lower volume than in the control muffin.

The muffin crumb images are shown in Figure 5, where it can be seen that the crumb structure of the control and Nutriose fat replacement formulations differed. The control had the typical structure of Spanish muffins, with bubbles of different sizes and a crumb with a dry appearance, while the muffin formulations with the higher Nutriose concentrations showed a moist crumb structure with no appreciable big bubbles. The structure of the $100 \% \mathrm{FR}$ muffins was difficult to cut with a knife, which stuck to the crumb.

One explanation for the lower number of air bubbles found in the nutriose muffins is that the delay in starch gelatinization delayed batter thermosetting, which does not favoured bubble retention although, as it was 
shown before, Nutriose promotes the formation of higher bubble size in the batter but these bubbles are unstable during heating.

Table 3. Height and volume values of the control Spanish muffin and the formulas in which fat was replaced by Nutriose.

\begin{tabular}{ccc}
\hline & $\begin{array}{c}\text { Height } \\
(\mathrm{mm})\end{array}$ & $\begin{array}{c}\text { Volume } \\
\left(\mathrm{cm}^{3}\right)\end{array}$ \\
\hline Control & $\begin{array}{c}48.24 \mathrm{a} \\
(0.86)\end{array}$ & $\begin{array}{c}114.50 \mathrm{a} \\
(5.98)\end{array}$ \\
\hline $25 \% \mathrm{FR}$ & $\begin{array}{c}45.80 \mathrm{~b} \\
(1.17)\end{array}$ & $\begin{array}{c}109.50 \mathrm{ab} \\
(3.51)\end{array}$ \\
\hline 50\%FR & $\begin{array}{c}44.21 \mathrm{c} \\
(1.31)\end{array}$ & $\begin{array}{c}108.75 \mathrm{~b} \\
(2.76)\end{array}$ \\
\hline $75 \% \mathrm{FR}$ & $\begin{array}{c}41.78 \mathrm{~d} \\
(0.70)\end{array}$ & $\begin{array}{c}106.25 \mathrm{~b} \\
(2.12)\end{array}$ \\
\hline 100\%FR & $\begin{array}{c}39.08 \mathrm{e} \\
(0.81)\end{array}$ & $\begin{array}{c}90.50 \mathrm{c} \\
(4.41)\end{array}$ \\
\hline
\end{tabular}

Values in parentheses are standard deviations. Means in the same column without a common letter differ $(P<0.05)$ according to the least significant difference multiple range test.
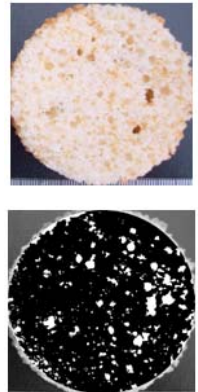

Control
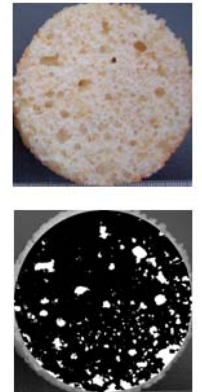

$25 \% \mathrm{FR}$
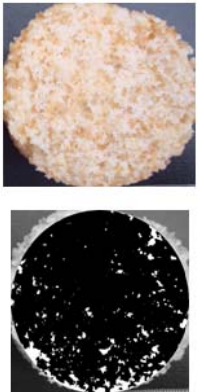

$50 \% \mathrm{FR}$
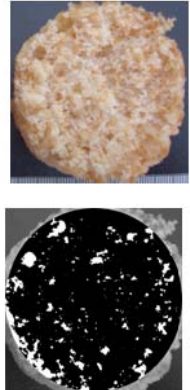

$75 \% \mathrm{FR}$
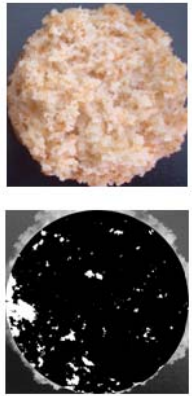

$100 \% \mathrm{FR}$

Figure 5. Photographs of cross-sections of control and Nutriose fat replacement Spanish muffins.

The volume of the muffins is determined by the air trapped in the batter, the capacity of the batter to retain this air and the moment at which starch gelatinization occurs. In this study, the batters with Nutriose trapped more air than those containing fat and should therefore have attained a greater volume. Furthermore, the gelatinization temperature was higher when Nutriose was 
present, causing an increase in the expansion time that in theory would lead to a greater volume, but this was not observed in our study. Consequently, the only thing that can explain the lower volume of the muffins with Nutriose is a lower gas-retention capacity during heating. Gas retention depends on the viscosity of the batter (or rather, the liquid between the bubbles) at the temperatures at which gas is generated. At $60-70{ }^{\circ} \mathrm{C}$, the viscosity was lower in the formulations with Nutriose, which could be associated with lower gas retention.

\subsection{Muffin texture}

The parameters obtained from the Texture Profile Analysis are shown in Table 4. The replacement of fat by Nutriose had a considerable effect on muffin hardness. All the samples with Nutriose had significantly lower hardness values $(P=0.001)$, causing a softer texture than in the control muffins. No differences were observed among the Nutriose samples for concentrations higher than $50 \%$. The same behaviour applied to springiness $(P=0.001)$ and chewiness $(P=0.001)$. Chewiness is a secondary texture parameter associated with difficulty in chewing the sample and forming a bolus before swallowing, and is related to hardness, springiness and cohesiveness. For both springiness and chewiness, the control muffins showed significantly higher values. Cohesiveness was not affected by fat replacement by Nutriose, so although the samples with $25 \%$ or $50 \%$ of Nutriose showed significantly lower values than the control, the $75 \% \mathrm{FR}$ and $100 \% \mathrm{FR}$ formulations did not exhibit significant differences. Resilience reflects the greater or lesser symmetry of the first compression curve and is related to the degree to which the sample recovers when compression ceases. A resilience value of 1 means that the sample behaves like a spring, returning immediately to its initial height. A dense structure containing little air will take longer to recover. In the present study, all the samples had low resilience values, which is typical of muffin formulations containing sugar and fat (Lu et al, 2010; Martinez-Cervera et al, 2011; Gomez et al, 2010; Baixauli et al, 2008), but those with over $50 \%$ fat replacement by 
Nutriose obtained significantly lower values than the control formulation $(P=0.000)$.

Table 4. Mean TPA values (H: hardness; S: springiness; Ch: cohesiveness; Cw: chewiness; R: resilience) of the control Spanish muffin and the formulas in which fat was replaced by Nutriose.

\begin{tabular}{cccccc}
\hline & \multicolumn{5}{c}{ TPA } \\
\cline { 2 - 6 } & $\mathrm{H}(\mathrm{N})$ & $\mathrm{S}$ & $\mathrm{Ch}$ & $\mathrm{Cw}(\mathrm{N})$ & $\mathrm{R}$ \\
\hline \multirow{2}{*}{ Control } & $16.20 \mathrm{a}$ & $0.88 \mathrm{a}$ & $0.56 \mathrm{a}$ & $7.92 \mathrm{a}$ & $0.28 \mathrm{a}$ \\
& $(0.57)$ & $(0.01)$ & $(0.00)$ & $(0.24)$ & $(0.01)$ \\
\hline \multirow{2}{*}{$25 \% \mathrm{FR}$} & $11.15 \mathrm{~b}$ & $0.85 \mathrm{ab}$ & $0.53 \mathrm{~b}$ & $4.99 \mathrm{~b}$ & $0.26 \mathrm{a}$ \\
& $(2.66)$ & $(0.03)$ & $(0.02)$ & $(0.92)$ & $(0.03)$ \\
\hline \multirow{2}{*}{$50 \% \mathrm{FR}$} & $7.80 \mathrm{c}$ & $0.80 \mathrm{bc}$ & $0.52 \mathrm{~b}$ & $3.26 \mathrm{c}$ & $0.23 \mathrm{~b}$ \\
& $(0.62)$ & $(0.02)$ & $(0.01)$ & $(0.33)$ & $(0.02)$ \\
\hline \multirow{2}{*}{$75 \% \mathrm{FR}$} & $5.77 \mathrm{c}$ & $0.75 \mathrm{c}$ & $0.56 \mathrm{a}$ & $2.40 \mathrm{~d}$ & $0.22 \mathrm{~b}$ \\
& $(0.49)$ & $(0.04)$ & $(0.02)$ & $(0.25)$ & $(0.01)$ \\
\hline \multirow{2}{*}{$100 \% \mathrm{FR}$} & $7.03 \mathrm{c}$ & $0.77 \mathrm{c}$ & $0.57 \mathrm{a}$ & $3.07 \mathrm{~cd}$ & $0.21 \mathrm{~b}$ \\
& $(1.52)$ & $(0.09)$ & $(0.02)$ & $(0.69)$ & $(0.02)$ \\
\hline
\end{tabular}

Values in parentheses are standard deviations. Means in the same column without a common letter differ $(P<0.05)$ according to the least significant difference multiple range test.

Usually, replacing part or all of the fat in muffins or cakes increases the hardness and springiness values. These changes in texture were observed by authors that used other fibres as fat replacer. Chung et al. (2010) observed similar results when studying the effect of $40 \%$ fat replacement by different types of waxy corn starch in muffins. The same results were obtained by Grigelmo-Miguel et al. (2001) when studying the effect of fat replacement by peach dietary fibre in muffins. However, when Martinez-Cervera et al (2011) replaced part of the fat with cocoa fibre they found a similar effect on texture to that presented by Nutriose: a decrease in hardness leading to muffins with a more tender and crumbly texture than the control muffins and a more compact and less aerated crumb.

In general, muffin hardness is inversely related to volume, so the smaller the volume of the muffin, the harder it is. In the Nutriose muffins, both the hardness and the volume were lower than those of the control formulation. In other words, that inverse relationship between hardness and volume was not 
encountered. The reason why the Nutriose muffins were less hard despite their lower volume must be associated to a softness effect of the presence of Nutriose ingredient in the complex muffin structure.

\subsection{DSC of the crumb}

The DSC analysis of the baked muffin in excess water revealed the appearance of an endothermic peak corresponding to the dissociation of the amylose-lipid complex (Figure 6) formed during muffin baking. No peak associated with starch gelatinization was found, indicating that all the starch presented in the muffin dough was completely gelatinized during the baking process.

The peak onset, peak temperature and enthalpy values are shown in Table 5. No significant differences in $T_{0}(P=0.573)$ and $T p(P=0.084)$ were found between the control and Nutriose muffins, implying that neither the oil nor the Nutriose exerted a significant influence on the amylose-lipid interaction.

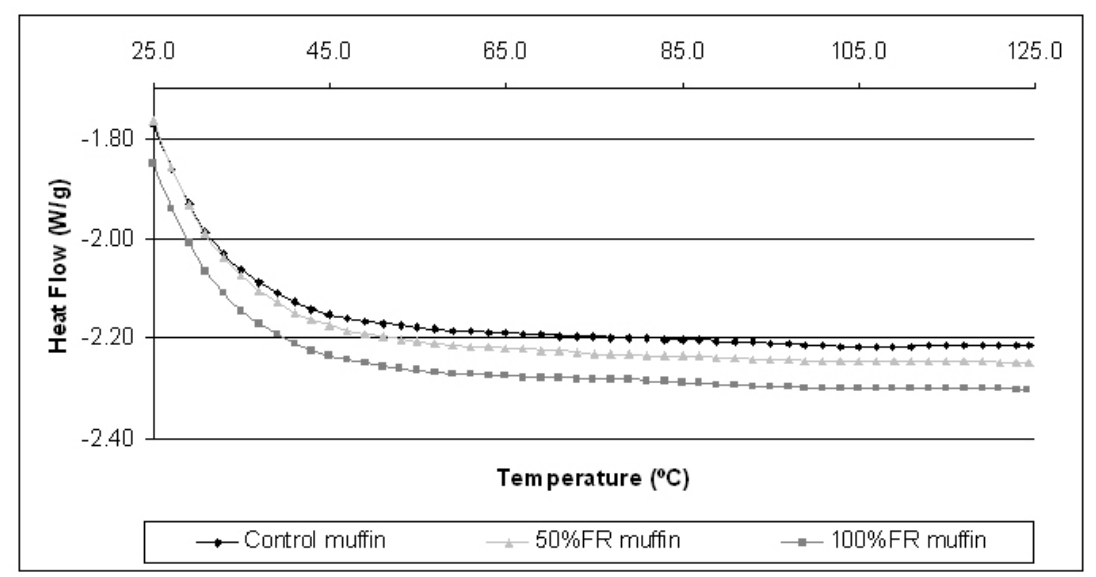

Figure 6. DSC thermograms of control and Nutriose fat replacement Spanish muffins. 
Table 5. Amylose-lipid complex enthalpy $(\Delta H)$, peak onset (To) and peak temperature (Tp) of the control Spanish muffin and the formulas in which fat was replaced by Nutriose.

\begin{tabular}{cccc}
\hline & \multicolumn{3}{c}{ Amylose-Lipid complex } \\
\cline { 2 - 4 } & $\Delta \mathrm{H}(\mathrm{J} / \mathrm{g})$ & $\mathrm{To}\left({ }^{\circ} \mathrm{C}\right)$ & $\mathrm{Tp}\left({ }^{\circ} \mathrm{C}\right)$ \\
\hline \multirow{2}{*}{ Control } & $\begin{array}{c}0.61 \mathrm{ab} \\
(0.06)\end{array}$ & $\begin{array}{c}89.15 \mathrm{a} \\
(0.62)\end{array}$ & $\begin{array}{c}98.58 \mathrm{a} \\
(2.12)\end{array}$ \\
\hline \multirow{2}{*}{$50 \% \mathrm{FR}$} & $\begin{array}{c}0.51 \mathrm{a} \\
(0.05)\end{array}$ & $\begin{array}{c}89.32 \mathrm{a} \\
(0.83)\end{array}$ & $\begin{array}{c}99.34 \mathrm{a} \\
(0.02)\end{array}$ \\
\hline \multirow{2}{*}{$100 \% \mathrm{FR}$} & $\begin{array}{c}0.89 \mathrm{~b} \\
(0.16)\end{array}$ & $\begin{array}{c}84.81 \mathrm{a} \\
(3.14)\end{array}$ & $\begin{array}{c}100.36 \mathrm{a} \\
(1.67)\end{array}$ \\
\hline
\end{tabular}

Values in parentheses are standard deviations. Means in the same column without a common letter differ $(P<0.05)$ according to the least significant difference multiple range test.

\subsection{Muffin acceptability.}

In bakery products with partial fat replacement, acceptability is an important parameter to measure. The fact that the presence of the fat influences palatability and other factors which are tightly bound up with acceptance and cannot be measured instrumentally makes affective sensory analysis indispensible in this type of research.

The average results of the sensory evaluation of the control and of muffins with $50 \%$ and $75 \%$ fat replacement by Nutriose are shown in Figure 7 . The sample with $50 \%$ of the fat replaced by the Nutriose showed no significant differences in overall acceptability, texture, flavour and sweetness scores compared with the control (Figure 7). The muffins with $75 \%$ fat replacement obtained lower scores for overall acceptance, appearance, colour and texture. No differences were found for flavour and sweetness. Control, $50 \%$ and $75 \%$ fat replacement formulations scored over 5 for overall acceptance, colour, flavour and sweetness and only $75 \%$ FR scored less than 5 for appearance and texture. Grigelmo-Miguel et al. (2001) obtained differences in acceptability in muffins when more than $34 \%$ of the fat was replaced by peach dietary fibre (other fibre used as fat replacer). 


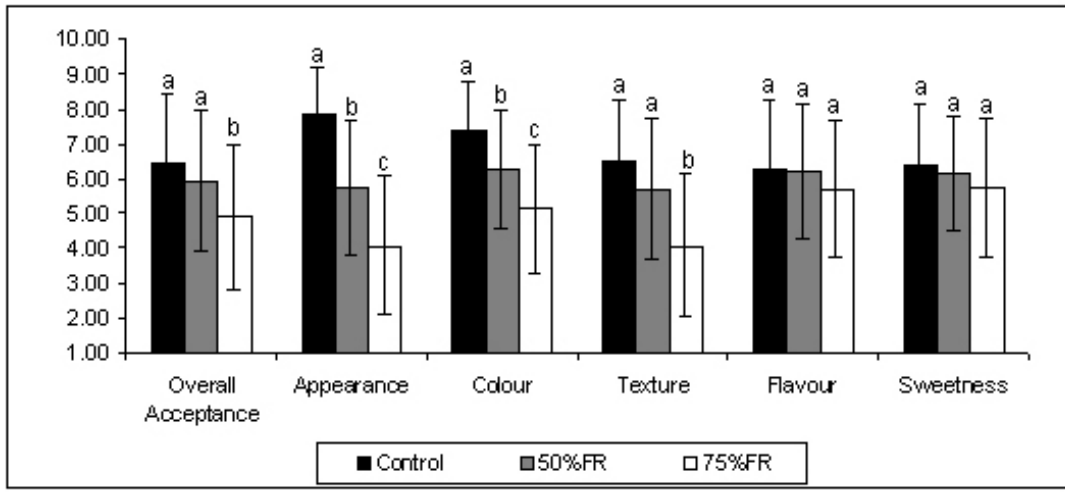

Figure 7. Sensory acceptability of low-fat Spanish muffins.

\section{Conclusions}

Apart from its own positive health effects, Nutriose can also be used as a fat replacer in muffins, up to a $50 \%$ fat replacement level, without significantly affecting consumer acceptability. Although the replacement of fat by Nutriose did affect the structure of the batter and of the baked muffin, this effect only became evident for levels of replacement higher than $50 \%$. Nutriose batters had higher total air content; however, Nutriose muffins had fewer air bubbles than the control, denoting a low capability of the batter to retain air bubbles during baking, probably because of the bubbles' higher initial size and the higher starch gelatinization temperature in the presence of Nutriose. The lower air bubbles of the Nutriose muffins were associated to lower volume. However, the Nutriose muffins showed lower hardness and springiness than the control, which can be associated to a softening effect of Nutriose in muffin texture

\section{References}

Baixauli R, Salvador A \& Fiszman SM (2008) Textural and colour changes during storage and sensory shelf life of muffins containing resistant starch. European Food Research and Technology 226, 523-530. 
Bath DE, Shelke K \& Hoseney RC (1992) Fat replacers in high-ratio layer cakes. Cereal Food World 37, 495-500.

Bodart M, de Peñaranda R, Deneyer A \& Flamant G (2008) Photometry and colorimetry characterisation of materials in daylighting evaluation tools. Building and Environment 43, 2046-2058.

Brooker BE (1993a) The stabilisation of air in foods containing fat - a review. Food Structure 12, 115-122.

Brooker BE (1993b) The stabilisation of air in cake batters - the role of fat. Food Structure 12, 285-296.

Chung HJ, Lee SE, Han JA \& Lim ST (2010) Physical properties of dry-heated octenyl succinylated waxy corn starches and its application in fat-reduced muffin. Journal of Cereal Science 52, 496-501.

Devereux HM, Jones GP, McCormack L \& Hunter WC (2003) Consumer acceptability of low fat foods containing inulin and oligofructose. Journal of Food Science 68, 1850-1854.

Francis FJ \& Clydesdale FM (1975) Color differences. En: Food Colorimetry: Theory and Applications (pás. 143-151). Editado por: FJ Francis \& FM Clydesdale. The Avi publishing company, Inc (Westport, Connecticut).

Frye AM \& Setser CS (1992) Optimizing texture of reduced-calorie yellow layer cakes. Cereal Chemistry 69, 338-343.

Ghiasi K, Hoseney R C \& Varriano-Marston E (1982) Effects of flour components and dough ingredients on starch gelatinization. Cereal Chemistry 60, 58-61.

Gomez M (2008) Low-sugar and Low-fat sweet goods. In Gülüm Sumnu, S and Sahin, $S$ (eds) Food engineering aspects of baking sweets goods. CRC Press. Boca Raton, FL, USA.

Gomez M, Moraleja A, Oliete B, Ruiz E \& Caballero PA (2010) Effect of fibre size on the quality of fibre-enriched layer cakes. Food Science and Technology 43, 33-38.

Grigelmo-Miguel N, Carreras-Boladeras E \& Martin-Belloso O (2001) Influence of the addition of peach dietary fiber in composition, physical properties 
and acceptability of reduced-fat muffins. Food Science and Technology International 7, 425-431.

Guerin-Deremaux L, Ringard F, Desailly F \& Wils D (2010) Effects of a soluble dietary fibre NUTRIOSE $\circledast$ on colonic fermentation and excretion rates in rats. Nutrition Research and Practice 4, 470-476.

Guerin-Deremaux L, Li S, Pochat M, Wils D, Mubasher M, Reifer C \& Miller LE (2011) Effects of NUTRIOSE $®$ dietary fiber supplementation on body weight, body composition, energy intake, and hunger in overweight men. International Journal of Food Sciences and Nutrition 62, 628-635.

Kalinga D \& Mishra VK (2009) Rheological and physical properties of low fat cakes produced by addition of cereal beta-glucan concentrates. Journal of Food Processing and Preservation 33, 384-400.

Kaur A, Singh G \& Kaur H (2000) Studies on use of emulsifiers and hydrocolloids as fat replacers in baked products. Journal of Food Science and Technology-Mysore 37, 250-255.

Khalil AH (1998) The influence of carbohydrate-based replacers with and without emulsifiers on the quality characteristics of lowfat cake. Plant Foods for Human Nutrition 52, 299-313.

Kim HYL, Yeom HW, Lim HS \& Lim ST (2001) Replacement of shortening in yellow layer cakes by corn dextrins. Cereal Chemistry 78, 267-271.

Kissell LT \& Bean MM (1978) AACC Technical Committee Report: Development of a method for angel food cake. Cereal Foods World 23 (3), 136-142.

Lakshminarayan SM, Rathinam V \& KrishnaRau L (2006) Effect of maltodextrin and emulsifiers on the viscosity of cake batter and on the quality of cakes. Journal of the Science of Food and Agriculture 86, 706-712.

Lee S, Kim S \& Inglett GE (2005) Effect of shortening replacement with oatrim on the physical and rheological properties of cakes. Cereal Chemistry 82 , 120-124.

Lefranc-Millot C (2008) NUTRIOSE $®$ 06: a useful soluble dietary fibre for added nutritional value. Nutrition Bulletin 33, 234-239. 
Li S, Guerin-Deremaux L, Pochat M, Wils D, Reifer C \& Miller LE (2010) NUTRIOSE dietary fiber supplementation improves insulin resistance and determinants of metabolic syndrome in overweight men: a double-blind, randomized, placebo-controlled study. Applied Physiology Nutrition and Metabolism-Physiologie Appliquee Nutrition et Metabolisme 35, 773-782.

Lin PY, Czuchajowska Z \& Pomeranz Y (1994) Enzyme-resistant starch in yellow layer cake. Cereal Chemistry 71, 69-75.

Lu TM, Lee CC, Mau JL \& Lin SD (2010) Quality and antioxidant property of green tea sponge cake. Food Chemistry 119, 1090-1095.

Martinez-Cervera S, Salvador A, Muguerza B, Moulay L \& Fiszman SM (2011) Cocoa fibre and its application as a fat replacer in chocolate muffins. LWT-Food Science and Technology 44, 729-736.

Pong, L., Johnson, J.M., Barbeau, W.E. and Stewart, D.L. (1991). Evaluation of alternative fat and sweetener systems in cupcakes. Cereal Chemistry 68, 552-555.

Pouillart PR, Depeint F, Abdelnour A, Deremaux L, Vincent O, Maziere JC, Madec JY, Chatelain D, Younes H, Wils D, Saniez MH \& Dupas JL (2010) Nutriose, a Prebiotic Low-digestible Carbohydrate, Stimulates Gut Mucosal Immunity and Prevents TNBS-induced Colitis in Piglets. Inflammatory Bowel Diseases 16, 783-794.

Rozan P, Deremaux L, Wils D, Hidalgo S, Bisson JF, Messaoudi M \& Saniez $\mathrm{MH}$ (2009) Food dextrin protects against colonic inflammation and prevents cognitive impairments. Current Topics in Nutraceutical Research 7, 141-147.

Shelke K, Faubion JM \& Hoseney RC (1990) The dynamics of cake baking as studied by a combination of viscometry and electrical resistance oven heating. Cereal Chemistry 67, 575-580.

Shukla TP (1995) Problems in fat-free and sugarless baking. Cereal Foods World 40,159-160.

Van den Heuvel EGHM, Wils D, Pasman W.J, Bakker M, Saniez M-H \& Kardinaal AFM (2004) Short-term digestive tolerance of different doses of 
NUTRIOSEsFB, a food dextrin, in adult men. European Journal of Clinical Nutrition 58, 1046-1055.

Vermorel M, Coudray C, Wils D, Sinaud S, Tressol JC, Montaurier C, Vernet J, Brandolini M, Bouteloup-Demange C \& Rayssiguier Y (2004) Energy value of a low-digestible carbohydrate, NUTRIOSE $® F B$, and its impact on magnesium, calcium and zinc apparent absorption and retention in healthy young men. European Journal of Nutrition 43, 344-352.

Warner K \& Inglett GE (1997) Flavor and texture characteristics of foods containing Z-Trim corn and oat fibers as fat and flour replacers. Cereal Foods World 42, 821-825.

Zahn S, Pepke F \& Rohm H (2010) Effect of inulin as a fat replacer on texture and sensory properties of muffins. International Journal of Food Science and Technology 45, 2531-2537. 


\section{RESUMEN Y DISCUSIÓN DE LOS RESULTADOS}





\section{RESUMEN Y DISCUSIÓN DE LOS RESULTADOS}

La presente tesis doctoral se enmarca dentro del proyecto de la Comisión Interministerial de Ciencia y Tecnología titulado "Reformulación de alimentos por adición de nuevos ingredientes comerciales para disminuir los contenidos en azúcar o grasas. Efectos sobre la reología, microestructura, propiedades sensoriales y aceptación".

El azúcar y la grasa, además del aporte de sabor, cumplen múltiples funciones en los alimentos como aportar consistencia y estructura a las masas crudas, o controlar el volumen y la forma de los productos finales, así como contribuir a la palatabilidad, textura y distribución de la humedad, entre otros factores que determinan su aceptación. Esta amplia complejidad funcional justifica la necesidad de estudios de investigación para realizar con éxito una reformulación de un producto. En concreto, este proyecto se centra en el estudio de las interacciones de estos nuevos ingredientes sustitutos de azúcar o grasa con el resto de los ingredientes y los cambios estructurales que introducen, así como su efecto sobre la calidad y la aceptación del producto final por parte del consumidor. En el proyecto se aborda el estudio de dos modelos de matrices alimentarias: uno de baja y otro de alta humedad.

En particular, esta tesis doctoral se centra en el estudio de un producto derivado de masa batida, las magdalenas, seleccionadas como modelo de matriz alimentaria de alto contenido en humedad.

El primer objetivo planteado fue seleccionar una formulación "control" tradicional poniendo a punto las características de una masa batida cruda y la proporción de cada uno de los ingredientes de una receta completa sin reducción de aceite y azúcar. Para ello se partió de listas de ingredientes utilizados en bibliografía $y$, tras realizar pequeñas modificaciones en las concentraciones de cada ingrediente, se obtuvo una formulación control que cumplía con todos los requisitos previos establecidos.

A continuación se plantearon una serie de objetivos encaminados a conocer la estructura de la masa batida y su comportamiento durante el 
procesado industrial y el desarrollo del producto final. Así se estudió el comportamiento reológico de las masas mediante ensayos de flujo y mediante ensayos de viscoelasticidad lineal en oscilatorio, las características térmicas mediante calorimetría diferencial de barrido y las características estructurales mediante análisis de imagen de la masa batida cruda.

La viscosidad de la masa es una propiedad física con una gran importancia en la calidad final de los productos horneados aireados. La viscosidad de la masa influye en el nivel de incorporación de aire durante el amasado. La retención de aire y gases derivados de la fermentación se refleja claramente en los valores de gravedad específica de la masa y es, en parte, función de la viscosidad de la masa. Además, la estabilidad de la burbuja y la generación de corrientes de convección en la masa durante la cocción dependen tanto de la viscosidad de la mezcla inicial como de la evolución de la viscosidad de la masa durante el calentamiento.

El estudio de la evaluación de la viscosidad en función de la velocidad de cizallamiento (curvas de flujo) indicó que en el intervalo de velocidades estudiado las masas se encontraban dentro de la zona pseudoplástica, es decir, la viscosidad disminuyó a medida que se aumentó la velocidad de cizallamiento. Los valores experimentales dentro de la zona pseudoplástica se ajustaron satisfactoriamente al modelo reológico de Ostwald-De Waele. Los distintos sustitutos de grasa y azúcar empleados afectaron al comportamiento de flujo de forma diferente. Por ejemplo, el reemplazo de la grasa por fibra de cacao aumentó los valores del índice de consistencia respecto a la muestra control. Este aumento excesivo de la consistencia podría producir problemas en la manipulación de la masa como, por ejemplo, en el llenado de los moldes (dosificación) y en la limpieza de la maquinaria. Por el contrario, el reemplazo de azúcar por polidextrosa y sucralosa obtuvo valores de índice de consistencia inferiores a la masa control, es decir, la masa presentaba menor viscosidad. Respecto al índice de comportamiento al flujo, el reemplazo de aceite por fibra de cacao produjo valores de índice de flujo menores, indicando una mayor resistencia al flujo y, por tanto, una mayor complejidad en la estructura de la 
masa. En el caso del reemplazo de azúcar por polidextrosa y sucralosa los valores de índice de flujo se aproximaron al valor de 1 , revelando una estructura más simple y próxima al comportamiento Newtoniano.

Con la finalidad de simular y monitorizar los cambios estructurales que sufre la masa durante el calentamiento en el horno, se realizaron rampas de temperatura de 25 a $95^{\circ} \mathrm{C}$ en el reómetro y se midieron las propiedades de viscoelasticidad lineal mediante ensayos en oscilatorio. Los cambios estructurales que ocurren en la masa durante el horneado son factores determinantes en la formación y evolución de las burbujas y en la estructura y textura del producto final. Por lo general, las masas mostraron una disminución del módulo elástico (G') y del módulo viscoso (G") durante el calentamiento desde $25^{\circ} \mathrm{C}$ hasta $60{ }^{\circ} \mathrm{C}$ o $75^{\circ} \mathrm{C}$, dependiendo de la formulación. En el intervalo de temperatura de 25 a $45^{\circ} \mathrm{C}$, aproximadamente, esta disminución en los valores de los módulos está asociada prioritariamente al efecto de aumentar la temperatura. A partir de $45^{\circ} \mathrm{C}$, la disminución de los módulos también se asocia a la formación de $\mathrm{CO}_{2}$ y a su difusión y expansión dentro de las celdas de aire, lo cual produce una disminución de la densidad de la masa. A partir de una determinada temperatura se produce un punto de inflexión en la curva, produciéndose un aumento en los valores de los módulos. Este cambio se asocia a la gelatinización del almidón y la coagulación de las proteínas, y se corresponde visualmente con el paso de una matriz fluida con consistencia semisólida a una matriz más sólida, la miga de la magdalena. Se observó que en una formulación sin azúcar ni sustitutos del mismo, el punto de inflexión se produjo alrededor de $60^{\circ} \mathrm{C}$. La presencia de azúcar retrasó la temperatura a la cual se produjo la inflexión de la curva hasta los $80-86^{\circ} \mathrm{C}$, lo que se asoció con un retrasó en la gelatinización del almidón y la desnaturalización proteica. Este aumento de la temperatura en la que se produce la formación de la miga favorece la expansión del $\mathrm{CO}_{2}$ y del vapor de agua, lo que origina la obtención de un producto final con una estructura de miga más aireada en presencia de azúcar. Para todos los sustitutos de azúcar, el punto de inflexión se obtuvo a menor temperatura que el obtenido para la formulación con azúcar, lo que 
indica que la gelatinización del almidón y la coagulación proteica se produjo antes $\left(69-78^{\circ} \mathrm{C}\right)$. En el caso del reemplazo de grasa por Nutriose ${ }^{\circledR}$ no se observó un cambio claro en el punto de inflexión de la curva, aunque sí se observó un suave aumento de los valores de G' y G", lo que se asoció a un aumento en la temperatura de gelatinización del almidón.

Con la finalidad de conocer mejor cómo afectan los sustitutos de grasa y de azúcar al proceso de gelatinización de almidón se realizó un estudio de las propiedades térmicas de la masa mediante calorimetría diferencial de barrido. La comparación del efecto de los distintos polioles y el azúcar sobre la gelatinización del almidón mediante esta técnica mostró que en presencia de sorbitol y eritritol el almidón presentó una temperatura de gelatinización ligeramente inferior a la presentada con el resto de edulcorantes. En el caso de la sustitución de grasa, el reemplazo con Nutriose ${ }^{\circledR}$ afectó a la temperatura de gelatinización del almidón, retrasándola en $8{ }^{\circ} \mathrm{C}$. En ninguno de los casos estudiados se encontraron diferencias significativas en la entalpía, por lo que la energía necesaria para que se diera lugar el proceso de gelatinización del almidón fue la misma.

La gravedad específica es un parámetro relacionado con la cantidad de aire que se encuentra en la masa, de tal modo que valores bajos de gravedad específica indican una alta aireación de la masa. Se observó que cuando el azúcar se eliminó de la formulación, se produjo una menor incorporación de aire, por tanto, el azúcar es un ingrediente que mejora la incorporación de aire y la capacidad de retención del mismo por la masa. Cuando el azúcar se reemplazó por una mezcla de sucralosa y polidextrosa se obtuvieron valores inferiores de gravedad específica respecto a los obtenidos por la formulación con azúcar, lo que indica que la sucralosa y polidextrosa mejoran la aireación de la masa. No ocurrió lo mismo cuando el azúcar se reemplazó por eritritol, obteniéndose valores de gravedad específica mayores. Con la finalidad de obtener mejores resultados de incorporación y retención de aire en las masas con eritritol se investigó el efecto de duplicar la cantidad de agente impulsor e introducir goma xantana. Se encontró una disminución en los valores de 
gravedad específica, por lo que se obtuvieron masas muy aireadas. En el caso del reemplazo de grasa por fibra de cacao o por Nutriose ${ }^{\circledR}$ se obtuvieron valores de gravedad específica inferiores a los obtenidos por la formulación con grasa, indicando que ambos ingredientes aumentaron la incorporación de aire durante el amasado.

Para conocer el tamaño y la distribución de las burbujas formadas, se realizó un estudio de análisis de imagen de las masas tras observarlas en un microscopio óptico, ya que la medida de la gravedad específica únicamente proporciona información sobre la cantidad de aire incorporado. Las imágenes obtenidas para las formulaciones control (con azúcar y grasa) mostraron un gran número de burbujas totales distribuidas de forma uniforme entre pequeñas, medianas y grandes. La eliminación del azúcar de la formulación redujo considerablemente el número de burbujas totales obtenido y las que se encontraban presentes eran mayoritariamente del tamaño más pequeño. Estos resultados junto con la alta gravedad específica obtenida indican que el azúcar posee un efecto muy importante en la incorporación de aire durante el amasado y en su retención en la masa. En el caso del reemplazo del azúcar por una mezcla de polidextrosa y sucralosa, se encontró un menor número de burbujas totales y de menor tamaño. Este resultado contrasta con la disminución del valor de gravedad específica e indica que a pesar de que se incorporó más aire durante el batido, éste no se retuvo en la masa. El motivo de la menor retención de aire se podría asociar a la menor viscosidad de estas masas, que favorecía la coalescencia de las burbujas (unión de burbujas formando una de mayor tamaño). El aumento del tamaño de las burbujas hace que la masa no sea capaz de retenerlas en su interior. En el caso del reemplazo de azúcar por eritritol se encontró un resultado similar al de la eliminación de azúcar, es decir, un menor número total de burbujas. Al incorporar goma xantana y mayor cantidad de agente impulsor no se encontraron diferencias respecto a los resultados obtenidos para la formulación con azúcar ni en número ni en tamaño de burbujas. Por último, cuando se reemplazó la grasa por Nutriose ${ }^{\circledR}$ se obtuvo mayor número de burbujas totales 
y burbujas de mayor tamaño, indicando que se produjo un aumento tanto en la incorporación como en la retención de aire.

Otro objetivo planteado en la presente tesis fue el estudio de los principales parámetros texturales de las magdalenas desarrolladas haciendo especial hincapié en aquéllos que se asocian a la "frescura" (producto recién horneado) mediante técnicas de textura instrumental. Para llevar a cabo este objetivo se realizaron ensayos de penetración, pegajosidad y análisis de perfil de textura. De todos ellos el que mejor información y mayor discriminación entre las muestras presentó fue el análisis de perfil de textura. Este ensayo consiste en realizar una doble compresión de la muestra obteniéndose los parámetros dureza, elasticidad, cohesividad, masticabilidad y resiliencia del análisis de las curvas obtenidas. Tras realizar un estudio de la evolución de la textura de la magdalena durante un periodo de 28 días de almacenamiento a temperatura ambiente, se determinó que la dureza y la elasticidad fueron los parámetros que mejor se asocian con la frescura del producto ya que se modificaron de forma significativa a lo largo de dicho periodo.

Cuando se eliminó el azúcar de la formulación se observó un aumento considerable de la dureza, que alcanzó un valor cuatro veces superior al obtenido por la formulación control. La eliminación de azúcar en cambio no afectó la elasticidad. El efecto del reemplazo de azúcar por los diferentes polioles dependió del tipo de poliol. En el caso del reemplazo por eritritol los valores de dureza aumentaron considerablemente y se observó una disminución en la elasticidad así como en el volumen del producto final, ya que la miga está más compactada. Los problemas de aumento de la dureza y disminución del volumen en el producto final se mejoran con la adición de mayor cantidad de agente impulsor y de goma xantana, obteniéndose valores de dureza inferiores a la muestra control. En el caso de reemplazo con isomaltitol no se observaron diferencias en la dureza de las magdalenas pero si que disminuyó la elasticidad. Sin embargo, cuando el azúcar se reemplazó por sorbitol, maltitol o por una mezcla de polidextrosa y sucralosa se observó una disminución tanto en la dureza como en la elasticidad. Por otro lado, cuando la 
grasa fue reemplazada tanto por fibra de cacao como por Nutriose ${ }^{\circledR}$, los valores de dureza y eslasticidad disminuyeron en ambos casos.

Además de la textura también existen otras características relacionadas con la estructura de la miga que pueden influir en la aceptabilidad del producto como son la forma, altura, volumen, número y distribución de las celdas de aire. Durante el horneado de la magdalena se van produciendo una serie de procesos en su interior, como la gelatinización del almidón, la coagulación de las proteinas y la evaporación de agua, de los que depende la formación de la miga. Para conocer la estructura de la miga se realizó un análisis de imagen de un corte transversal de la magdalena, a traves del cual se pudo observar tanto la cantidad como la distribución de las celdas de aire. La eliminación del azúcar produjo una disminución en el número total de celdas de aire y la formación de túneles verticales a lo largo de toda la superficie estudiada. Las celdas de aire que se encontraron fueron, en comparación con la formulación control, de un tamaño mucho más grande. Estos resultados indicaron que en ausencia de azúcar se produjo una coalescencia de las burbujas de la masa y una pérdida importante de aire en el horneado. Cuando el azúcar se reemplazó por eritritol no se observaron diferencias en el número total de celdas de aire respecto a la formulación control, pero si una ligera diferencia en la distribución de las mismas, ya que se encontró un menor número de celdas de tamaño intermedio y un mayor número de celdas de mayor tamaño. No obstante, se observó que al añadir goma xantana y doble concentración de agente impulsor se redujeron estas pequeñas diferencias y la estructura fue más parecida a la formulación control. Paralelamente, cuando el azúcar se reemplazó por una mezcla de polidextrosa y sucralosa se observó una disminución en el número total de celdas de aire y un cambio en su distribución. En este caso se obtuvo menor cantidad de celdas de aire de tamaño grande y mayor cantidad de celdas pequeñas, lo que se relacionó con el termosellado precoz de la corteza de la magdalena durante el horneado, que impide una correcta expansión de las burbujas. En el caso del reemplazo de grasa por Nutriose ${ }^{\circledR}$ se observó una estructura de la miga de aspecto húmedo 
y sin grandes burbujas apreciables. En el caso de las formulaciones con mayor porcentaje de sustitución no se pudo determinar correctamente el número de celdas de aire totales y su distribución debido a la resistencia al corte de la muestra. No obstante, se observó cierta tendencia a la disminución tanto en el número total de celdas de aire como en el número de celdas de mayor tamaño.

El volumen como la altura de las magdalenas son dos parámetros críticos importantes que se deben conocer en los productos aireados, ya que están muy relacionados con la estructura de la miga y con la textura del producto final. El volumen final de las magdalenas está influenciado por la cantidad de aire incorporado durante el batido, la capacidad de la masa para retener las burbujas formadas y por el proceso de gelatinización del almidón durante el horneado, entre otros factores. La eliminación de azúcar produjo una disminución tanto en la altura como en el volumen del producto final, asociada al papel fundamental del azúcar en la incorporación de aire y a su estabilidad antes y durante el horneado. Un reemplazo de azúcar por eritritol o por una mezcla de polidextrosa y sucralosa superior al $50 \%$ produjo una disminución en la altura y en el volumen de las magdalenas. Por otro lado, la altura y el volumen también se vieron afectados con el reemplazo de grasa por fibra de cacao o por Nutriose ${ }^{\circledR}$. Por lo general, la incorporación de cualquier tipo de fibra produce un descenso en la altura y el volumen del producto final, ya que se disminuye la incorporación de aire durante el amasado y se aumenta la viscosidad del producto.

Finalmente, se han desarrollado dos objetivos relacionados con el análisis sensorial de las magdalenas. En concreto, se evaluaron las características sensoriales de las magdalenas generando los descriptores que mejor definían la calidad sensorial del producto utilizando un panel de catadores entrenados. Se generaron descriptores relacionados con las características de aspecto, textura, aroma y sabor. Además, también se estudió la aceptación de los nuevos productos utilizando un panel de consumidores.

Para la realización del análisis sensorial descriptivo se entrenó a 10 jueces con experiencia previa en análisis sensorial de productos de bollería. 
Las muestras evaluadas fueron magdalenas con reemplazo de grasa por fibra de cacao. El panel de jueces entrenados sugirió los siguientes descriptores, algunos de los cuales eran distintivo de los efectos de la fibra soluble de cacao: altura, color chocolate, esponjosidad, elasticidad, adherencia al molde, cohesión, dificultad en la masticación y deglución, sabor amargo, sabor dulce y sabor a chocolate. Todos los atributos variaron significativamente con la adición de fibra de cacao como sustituto de la grasa, excepto el sabor dulce. La formulación control se definió como la formulación con mayor adherencia al molde, altura, esponjosidad, elasticidad, sabor y color a chocolate. Por el contrario, las formulaciones con mayor porcentaje de sustitución de grasa por fibra de cacao se definieron como más cohesivas, con peor masticabilidad y mayor sabor amargo.

Por ultimo, para conocer la aceptación del consumidor de las nuevas formulaciones se realizaron diferentes estudios sensoriales con 100 consumidores habituales de productos de bollería. En este caso se pidió a los consumidores que evaluaran los atributos de apariencia, color, textura, sabor, dulzor y aceptación general. En todos los casos estudiados, la formulación control (la que contenía toda la grasa y el azúcar) fue bien valorada por los consumidores en todos los atributos. Cuando se valoró el reemplazo de azúcar por edulcorantes no se encontraron diferencias en la aceptación de las formulaciones con $100 \%$ de reemplazo de azúcar por sorbitol o maltitol o en el caso de reemplazo del $50 \%$ de azúcar por polidextrosa y sucralosa. Al igual que ocurrió con el reemplazo de azúcar, no se encontraron diferencias en aceptación en las formulaciones en las que el $50 \%$ de la grasa fue reemplazado por Nutriose ${ }^{\circledR}$. Sin embargo, un reemplazo superior al $25 \%$ de la grasa con fibra de cacao reveló puntuaciones significativamente más bajas que las obtenidas para la formulación control. 
CONCLUSIONES 



\section{Conclusiones}

Las principales conclusiones que se extraen de la presente tesis doctoral son:

- El conocimiento de la función de cada uno de los ingredientes de las magdalenas permite la elección de sustitutos que disminuyan el aporte energético o equilibren la composición nutricional sin producir una disminución en la calidad del producto.

- El estudio de las propiedades reológicas, térmicas y estructurales de la masa de un producto de bollería de masa aireada permite realizar una predicción del comportamiento de dicha masa durante el horneado y su relación con la textura final del producto.

- La funcionalidad del azúcar es determinante en la calidad de la magdalena final. A nivel de la masa el azúcar favorece la incorporación de aire y su estabilidad. Posteriormente, durante el calentamiento en el horno, aumenta la temperatura de gelatinización del almidón y de la coagulación proteica, aspectos clave en la correcta expansión de las burbujas de gas y el desarrollo de una estructura aireada antes de que se produzca el termosellado. La consecuencia es el desarrollo de una altura, volumen, estructura de la miga y textura óptimos.

- El eritritol es capaz de simular sólo parcialmente la funcionalidad del azúcar. El eritritol produjo un aumento en la incorporación de aire durante el amasado y en la altura de las magdalenas en comparación con las magdalenas sin azúcar. Sin embargo, el efecto del eritritol no fue suficiente para mejorar el volumen y textura del producto final. 
- El efecto positivo del eritritol en las propiedades de las magdalenas se asocia a que, al igual que el azúcar, produce una disminución en la elasticidad durante el calentamiento y eleva la temperatura de gelatinización del almidón.

- La combinación de eritritol con goma xantana y doble cantidad de agente impulsor resultó eficaz para mejorar las propiedades de textura de las magdalenas, reduciendo la dureza y aumentando la altura y el volumen gracias al aumento de la incorporación de aire durante el amasado.

- Un reemplazo mayor al $25 \%$ de azúcar por sucralosa y polidextrosa afectó progresivamente a la estructura de la masa, tanto antes como durante el calentamiento, disminuyendo la viscosidad y la viscoelasticidad de la masa así como la temperatura de termosellado del producto. Estas circunstancias no favorecieron la expansión adecuada de las burbujas de aire y produjeron una magdalena de estructura de miga cerrada y de menor altura. No obstante, el reemplazo del 50\% del azúcar por sucralosa y polidextrosa no produjo una disminución en la aceptación sensorial de la magdalena.

- El reemplazo total de azúcar por maltitol, isomaltitol o sorbitol no alteró el termosellado de la masa y las magdalenas obtenidas mostraron buenas propiedades de textura y de aceptabilidad sensorial. No obstante, los resultados de aceptabilidad de los consumidores y de textura instrumental indicaron que el eritritol es el poliol menos adecuado para la sustitución total del azúcar en magdalenas.

- La fibra de cacao es una buena opción para reemplazar parte del aceite en una formulación de magdalenas con sabor a cacao. Sin embargo, hay puntos mejorables como pérdida de altura, percepción de sabor amargo y cierta pegajosidad en la superficie. 
- Las principales ventajas de la adición de fibra de cacao son que proporciona mayor humedad a la magdalena, brinda una textura más tierna y disminuye el envejecimiento durante el almacenamiento. Para una magdalena de chocolate, la adición de fibra de cacao proporciona un buen color a chocolate con menor cantidad de cacao.

- Las masas con Nutriose ${ }^{\circledR}$ tienen un mayor contenido de aire total, sin embargo, las magdalenas tienen menos celdas de aire que la formulación con grasa, lo cual indica una baja capacidad de la masa para retener burbujas de aire durante la cocción, que se relaciona con un aumento en la temperatura de gelatinización del almidón produciéndose el termosellado de la estructura a una temperatura superior a la temperatura óptima.

- El Nutriose ${ }^{\circledR}$ es adecuado como sustituto de la grasa en magdalenas hasta un nivel de sustitución de 50\%, sin afectar la aceptabilidad por el consumidor. 


